\title{
COMPETÊNCIA EM COMUNICAÇÃO: uma ponte entre aprendizado e ensino na Enfermagem
}

Tese apresentada à Escola de Enfermagem da Universidade de São Paulo para obtenção do Grau de Doutor em Enfermagem.

Orientadora:

Profa. Dra. Maria Júlia Paes da Silva

São Paulo

2004 
Catalogação na publicação (CIP)

Biblioteca "Wanda de Aguiar Horta" da EEUSP

\section{Braga, Eliana Mara}

Competência em comunicação: uma ponte entre aprendizado e ensino na Enfermagem / Eliana Mara Braga. - São Paulo: E. M. Braga; 2004. $172 \mathrm{p}$.

Tese (Doutorado) - Escola de Enfermagem da Universidade de São Paulo.

Orientadora: $\operatorname{Prof}^{\mathrm{a}}$. Dr ${ }^{\mathrm{a}}$. Maria Júlia Paes da Silva

1. Comunicação em enfermagem (estudo e ensino) 2. Interação interpessoal 3. Educação em enfermagem 4. Competência profissional 5. I. Título. 
Em que pensar...

tudo o que é verdadeiro, tudo o que é respeitável, tudo o que é justo, tudo o que é puro, tudo o que é amável, tudo o que é de boa fama se alguma virtude háe se algum louvor existe, seja isso o que ocupe o vosso pensamento.

Filipenses 4:8. 


\section{Dedicatória}

Ao Felipe, que me mostrou o que é o amor

Ao Vanderlei, meu amor companheiro

A meus pais, Ana e Darcy, pelo amor incondicional

A minha querida irmã Eliude, ao Délcio e ao Samuel

\section{A Maria Júlia,}

Que sempre me acompanhou

com sua luz,

indicando-me as possibilidades

do ensino da comunicação

A Marli Rolim que me mostrou

o exemplo do acolhimento

verdadeiro 


\title{
Agradecimento Especial
}

\author{
Aos professores de Enfermagem
}

que participaram deste estudo, contribuindo

com suas trajetórias de vida, suas experiências

e seus modelos no ensino. 


\section{AGRADECIMENTOS}

Às minhas queridas amigas de todas as horas, dos bons e dos não tão bons momentos...

Às amigas de todas as horas e, também, as do cafezinho...

É impossível agradecer tudo o que vocês significam na construção deste e de muitos outros momentos de minha vida....

Sei que vocês se identificam aqui.

Muito obrigada, sempre!

Aos mestres, alunos e pacientes, meu reconfecimento

pelo aprendizado de cada dia. 
À Escola de Enfermagem da Universidade de São Paulo, EEUSP, pela oportunidade Aos secretários da Seção de Pós-graduação da EEUSP

Aos departamentos e secretários da EEUSP

Às Gibliotecárias da EEUSP

À Universidade Estadual Paulista, UNESP

Ao Departamento de Enfermagem da UNESP, pelo apoio e incentivo

Ao Conselho $\mathcal{N a c i o n a l}$ de Desenvolvimento Científico e Tecnológico, CSPq, pelo apoio financeiro 
Braga EM. Competência em comunicação: uma ponte entre aprendizado e ensino na enfermagem. [tese] São Paulo (SP): Escola de Enfermagem da USP; 2004.

\section{Resumo}

Este estudo teve como objetivo caracterizar referenciais de competências comunicativas interpessoais e propor bases teórico-metodológicas para 0 aprendizado da comunicação interpessoal no ensino da Enfermagem. Abordando questões norteadoras sobre competência em comunicação interpessoal, utilizouse referencial teórico de comunicação e método de análise de conteúdo em 13 discursos de professores de Enfermagem, especialistas em comunicação. Os resultados obtidos representam que a competência em comunicação é um processo interpessoal que deve atingir o objetivo dos comunicadores, pressupor conhecimentos básicos de comunicação, ter consciência do verbal e do nãoverbal nas interações, atuar com clareza e objetividade, promover o autoconhecimento e, conseqüentemente, ter a possibilidade de uma vida mais autêntica. Os sujeitos relatam que a expressão da competência comunicativa está, necessariamente, no vivenciar o cotidiano profissional e pessoal, ouvindo o outro, prestando atenção na comunicação não-verbal, validando a compreensão das mensagens, sendo capaz de eliminar as barreiras impostas à comunicação, demonstrando afetividade e investindo no autoconhecimento. $\mathrm{O}$ desenvolvimento da competência comunicativa verifica-se pelo estímulo recebido desde a graduação, pelas leituras de aprofundamento do tema, pela prática profissional e realização de pesquisas e publicações na área. O ganho alcançado com a competência em comunicação interpessoal resulta em relações profissionais e pessoais mais significativas, maior autoconsciência e aceitação das diferenças do outro, ampliação dos caminhos do ensino e da pesquisa e conquista de um bemestar. Os teóricos mais citados como referenciais, pelos sujeitos do estudo, foram: Stefanelli MC., Silva MJP., Travelbee J., Littlejohn SW., Davis F., Rogers CR., Sullivan HS., Ruesch J., Peplau HE., Bales RF. e Moscovici F. As bases metodológicas propostas para 0 aprendizado e ensino da comunicação interpessoal em Enfermagem, são: assumir a comunicação como base para o 
cuidar, ensinar os fundamentos teóricos da comunicação no início da graduação, desenvolver a competência de todos os professores em comunicação, vincular a prática assistencial com o ensino da comunicação, acompanhar a progressão da competência comunicativa no aluno e vivenciar a comunicação efetiva com as pessoas na escola. Os resultados que emergiram deste estudo permitem considerar a competência em comunicação interpessoal, como uma habilidade fundamental a ser adquirida pelo enfermeiro, sabendo que esta lhe possibilitará um cuidar consciente, verdadeiro e transformador.

Palavras-chave: comunicação em enfermagem, comunicação interpessoal, educação em enfermagem, competência profissional, ensino-aprendizagem. 
Braga EM. Competence in communication: a bridge between learning and teaching in nursing .[thesis] São Paulo (SP): Escola de Enfermagem da USP; 2004.

\section{Abstract}

This study aimed at characterizing references of interpersonal communicative competence and proposing theoretical methodological bases for interpersonal communication learning on nursing teaching. Through guiding questions about competence on interpersonal communication, the theoretical reference of communication and the method of the content analysis in thirteen communication expert nursing teachers' speeches were used. The results show that competence in communication is an interpersonal process which must reach the communicator's objectives, require basic knowledge of communication, have verbal and non-verbal perception in the interactions, act clearly and objectively, develop self-knowledge and, therefore lead to the possibility of a more legitimate life. The subjects report that the communicative competence expression is necessarily, in the living of the professional and personal every day life, listening to the other, perceiving nonverbal communication, validating the message understanding, being able to break communication barriers, showing affection and developing self-knowledge. The development of a communicative competence has been reached by the stimulus received since the undergraduation course, by reading deeply the theme, by professional practice and by accomplishing research as well as publishing in the field. The benefits originated from competence in interpersonal communication lead to a more significant professional and personal relationship, a better self-knowledge and acceptance of the other's differences, a widening on ways of teaching and researching as well as an achievement of welfare. The most cited theorists as reference by the study subjects were as follows: Stefanelli MC., Silva MJP., Travelbee J., Littlejohn SW., Davis F., Rogers CR., Sullivan HS., Ruesch J., Peplau HE., Bales RF. E Moscovici F. The target methodological bases for interpersonal communication learning and teaching in 
nursing are: assuming communication as the basis for caring, teaching the communication theoretical principles in the beginning of the undergraduation course, developing the communication competence of all teachers, linking assistance practice to communication teaching, following the student communicative competence progression and living the effective communication with people in the school. The results coming out from this study allow us to consider competence in interpersonal communication as a major ability to be acquired by the nurse, being aware that it will enable a conscious, true, and transforming care.

Key words: communication in nursing, interpersonal communication, education in nursing, professional competence, teaching and learning. 


\section{LISTA DE ESQUEMAS}

Esquema 1- Os significados da comunicação competente

Esquema 2- Os referenciais de competência comunicativa

Esquema 3- A expressão da competência comunicativa

Esquema 4- Como se desenvolve a competência comunicativa 106

Esquema 5 Bases para o ensino de comunicação em Enfermagem 114

Esquema $6 \quad 0$ ganho com a competência comunicativa 


\section{SUMÁRIO}

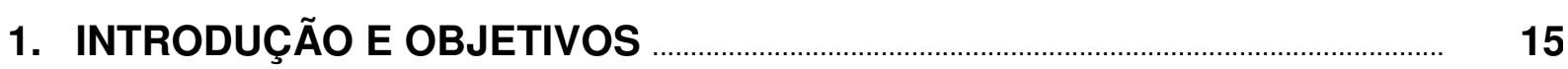

1.1 Introdução

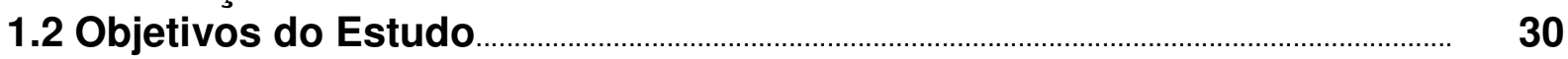

2. REFERENCIAL TEÓRICO E METODOLÓGICO _................................................... 32

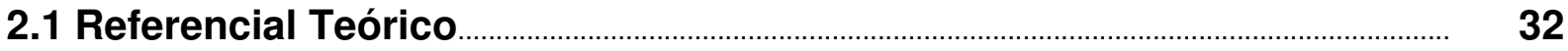

2.2 Referencial Metodológico ................................................................................................ 37

3. APRESENTAÇÃO DOS RESULTADOS E ANÁLISE DOS DADOS $\ldots \ldots \ldots \ldots \ldots \ldots \ldots . . . \quad 44$

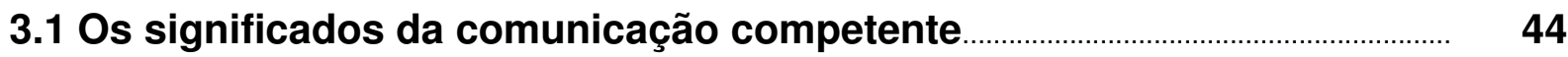

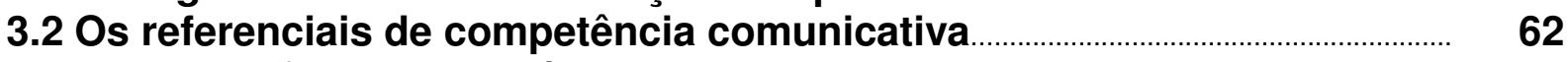

3.3 A expressão da competência comunicativa $\ldots$

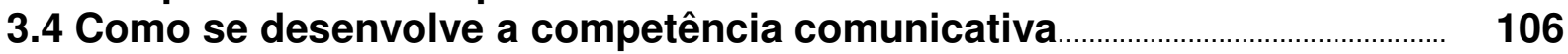

3.5 Bases para o ensino de comunicação em Enfermagem ..................................... 114

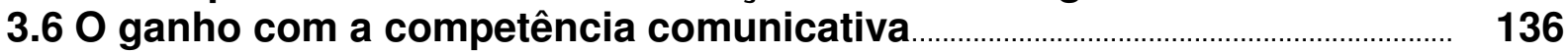

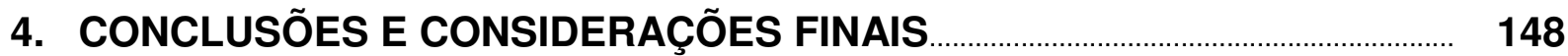

4.1 Os referenciais de competências comunicativas interpessoais para o $\quad 148$ ensino da Enfermagem.

4.2 As bases teórico-metodológicas para o aprendizado de comunicação 149 interpessoal em Enfermagem.

4.3 Considerações Finais. 
"De minha paixão pela educação,

estou semeando as sementes

de minha mais alta esperança.

Não busco discípulos para

comunicar-Thes saberes,

6usco discípulos para neles

plantar minhas esperanças."

Rubem Alves 


\subsection{Introdução}

Iniciamos este estudo com base nas conclusões obtidas em nossa dissertação de mestrado, em que constatamos a existência de comportamentos comunicativos verbais e não-verbais do docente de Enfermagem que podem motivar o aluno a aprender ${ }^{(1)}$

De acordo com a dinâmica utilizada, a boa comunicação professor-aluno e um conteúdo significante aos envolvidos, os comportamentos podem facilitar a interação em sala de aula. Do mesmo modo, podem dificultar a interação, quando há pouco tempo disponível para a aula, inibição de alguns alunos e falta de interesse pelo tema.

Os resultados do estudo propiciaram concluir que, na comunicação em sala de aula, motivação, capacidade de síntese e a coerência entre verbal e nãoverbal do professor são muito importantes ao aprendizado do aluno.

Nesta pesquisa, os sujeitos sugeriram mudanças nas interações em sala de aula que poderiam contribuir para a facilitação da aprendizagem, propuseram diversificação de métodos de ensino por meio de aulas inovadoras que lhes permitissem ser ouvidos, ter oportunidade de participação e diálogo, além do bom aproveitamento do tempo destinado à aula ${ }^{(1)}$.

Estas constatações serviram de motivação para explorarmos os referenciais de competência em comunicação dos professores comprometidos com o ensino da Enfermagem. 


\section{A comunicação}

Littlejohn $^{(2)}$ considera que a comunicação é um processo de natureza complexa e multidisciplinar, que se constitui em numerosos aglomerados de comportamentos que afetam, cotidianamente, nossas comunicações com os outros que podem ser influenciados até pelas comunicações de pessoas distantes e desconhecidas.

A comunicação faz com que as pessoas se relacionem, compartilhando experiências, idéias e sentimentos e, ao se relacionarem, influenciam-se, modificando a realidade em que estão inseridas ${ }^{(3)}$.

As relações são sempre marcadas por interferências ou reações voluntárias, ou involuntárias, intencionais ou não, e compreendem o processo de interação humana em que uma pessoa não fica indiferente na presença de outra $^{(4)}$.

Gaiarsa $^{(5)}$ afirma que a relação com o outro sempre existe, quer queiramos ou não, o outro está sempre aí, nos envolve por fora e nos invade por dentro. Tudo o que somos e fazemos forma-se e acontece na relação com os outros.

\section{A comunicação no ensino}

O professor deve ser um comunicador que desperte o interesse dos alunos e considere os aspectos psicológicos envolvidos no processo de aprendizagem, não deve se deter apenas em codificar sua mensagem, como comumente é feito, mas torná-la decodificável para o aluno. A preocupação do professor com a 
reação dos alunos é importante, pois o comunicador precisa ter a capacidade de perceber a reação do outro e ser uma pessoa sensível nas relações humanas ${ }^{(6)}$.

As afirmações de Gagné $^{(7)}$ mostram que o professor usa seu conhecimento para tomar decisões adequadas a respeito das realizações para as quais o estudante está motivado, fornecendo uma orientação conveniente às prováveis aprendizagens que Ihe possam ser úteis no futuro. Nesse sentido, o professor é a maior fonte de estimulação para o aluno aprender.

As complexidades de situações em sala de aula devem ser consideradas, pois incluem a presença de muitos alunos com e sem motivação, aptidões desiguais, dificuldades de comunicação entre professor-aluno, características particulares da disciplina e da idade dos alunos. Aspectos motivacionais de personalidade, de grupo, sociais e do professor exercem grande influência na aprendizagem e seus efeitos são visíveis, tais como focalização da atenção, persistência e crescente tolerância à frustração ${ }^{(8)}$.

A tarefa de comunicar é mais fácil e efetiva quando o professor conhece bem seus alunos, pois isto significa que sabe seus repertórios comunicativos, suas idéias, experiências, signos e está interessado em ajudá-los a modificar e aumentar esses repertórios. Assim, a emissão, transmissão e recepção de informação são apenas algumas das funções da comunicação entre professor e alunos. Da boa comunicação, dependem não só a aprendizagem, mas também o respeito mútuo, a cooperação e a criatividade ${ }^{(9)}$.

Masetto e Abreu ${ }^{(10)}$ afirmam que a aula é um encontro, repetido durante espaços de tempo predeterminados e, nesse encontro, seres vivos, seres humanos, confinados dentro dos limites da classe, defrontam-se, comunicam-se e 
influenciam-se. A razão central desse encontro é a aprendizagem do aluno, que é influenciada pelo modo de agir do professor em sala de aula, mais do que suas características de personalidade.

Neste contexto, a Drª . Elsa Garrido*, professora da Faculdade de Educação da Universidade de São Paulo, cita a interação em sala de aula, como uma dinâmica de envolvimento e interesse, em que o professor permite ao aluno interagir com liberdade. Professor e aluno necessitam desse encontro de adaptação social e cultural, para que os preconceitos sejam rompidos e conflitos e resistências, administrados.

Segundo a abordagem dessa educadora, toda aula tem uma parte manifesta e intencional, na qual colocamos nossos objetivos e uma parte nãointencional que acontece independente de nossa vontade.

Poderíamos entender estas citações como os aspectos não-verbais, ou seja, forma de falar, olhar, andar, sentar, interromper, agredir, etc. Estas formas estão presentes na interação e nos colocam em exposição, sem que possamos perceber de forma consciente ou voluntária.

Silva ${ }^{(11)}$ confirma estes aspectos ao relatar que, na comunicação nãoverbal, o indivíduo participa simultaneamente de duas dimensões existenciais decorrentes de dois modos de se relacionar com o mundo: uma verbal que the confere um repertório psicolingüístico e outra não-verbal que the proporciona um estatuto psicobiológico, proporcionando, no verbal uma exteriorização do ser social e no não-verbal, uma exteriorização do ser psicológico.

"GARRIDO, E. (1998) - Notas de aula "Perspectivas do Ensino de Enfermagem" ministrada na Escola de Enfermagem da USP. 
A pessoa do professor revela vários signos ao aluno: o signo icônico que significa sua aparência, cor da pele, roupa, classe social, a forma exteriorizada de ser e tudo o que ele representa visualmente, o signo lingüístico concentra-se na língua, com a qual se comunica, e o signo cibernético compreende os movimentos e os gestos ${ }^{(6)}$.

Bezerra $^{(6)}$ destaca ainda que o uso da linguagem, dos símbolos e das expressões são códigos e estilos pessoais que podem facilitar a inter-relação. O professor, como signo, impõe-se a si mesmo, assim cria a estrutura do ambiente da classe. A sua intenção deve ser coerente com sua ação e postura, promovendo a participação do aluno na aprendizagem, sem "dominar a situação", sem ter em sala de aula um ambiente artificial, no qual o poder é exercido de forma autoritária e o pensamento e as ações não se identificam. O autor citado refere que o ato educativo deve acentuar as relações e não as características de uma só pessoa, o que nos remete para o atual paradigma de comunicação que coloca em igualdade emissor e receptor.

Desse modo, a comunicação é algo que conhecemos, sentimos e vivenciamos e a mensagem deve ser um conteúdo bem-estruturado na compreensão do professor, ligado às emoções e vivenciado, isto é, deve fazer parte de seu cotidiano ${ }^{(6)}$.

Em sua forma verbal, a linguagem como signo carrega nossa cultura, emoções, crenças e preconceitos que são explicitados por meio da forma nãoverbal. Os estímulos não-verbais de comunicação podem ser usados para tornar mais clara a mensagem ao aluno por meio da postura corporal, contato dos olhos, 
disposição dos móveis, roupas, expressões faciais, volume e ritmo de voz, distância interpessoal, uso do toque e do paraverbal ${ }^{(11)}$.

O estudo de Bezerra(6) mostra que as relações professor-aluno fundamentam-se em fatores determinantes, que são as características pessoais, sociais e escolares.

As características pessoais: tanto do professor como do aluno revelam suas qualidades inatas que facilitam a relação e seus traços negativos, que dificultam o relacionamento. O envolvimento pessoal do aluno insere-o em cada evento de forma direta, levando-o a descobrir e resolver problemas, experienciando cada situação com seus colegas, sempre priorizando sua imersão no ato de aprender como pessoa e não como uma máquina produtora de raciocínio e conceitos.

Nas características pessoais, espera-se autenticidade do professor. É preciso que ele veja-se como pessoa e não apenas como um profissional, que assuma o compromisso de revelar-se como um ser real, sem adotar apenas a postura própria do papel social. Ser pessoa autêntica facilita a relação de confiança e abre espaço para a interação. Do mesmo modo, o aluno deve ser compreendido como o que precisa aprender e, por isso, busca o conhecimento que o professor tem para dar, enfim, um convívio entre pessoas que reagem com sentimentos e compreendem com uma percepção cognitivo-afetiva.

Nas características sociais, sabemos que a sociedade é uma coletividade organizada por pessoas que interagem e assemelham-se em razão de objetivos comuns, características culturais, valores, crenças e comportamento coletivo. Atualmente, verificam-se várias transformações no perfil do aluno e do professor 
como, por exemplo, as transformações políticas que abrem o país para a democratização, fazem com que o professor não possa ter uma postura autoritária nem o aluno uma atitude passiva ou dependente, sendo o professor o maior responsável por determinar o tipo de interação que haverá entre eles.

Nas características escolares, observamos que no sistema escolar professor e o aluno assumem papéis de reciprocidade que contribuem para a interação. Cada escola organiza as suas relações, atitudes e valores para manter o comportamento de seus membros, de acordo com padrões preestabelecidos. Já a sala de aula pode ser considerada um microsistema social dentro da escola, um sistema mais amplo conforme o professor e o aluno mantêm e seguem padrões e regras de comportamento. Compreendemos, então, que a relação professor-aluno não se limita apenas ao conteúdo comportamental, mas, a uma extensão do controle que o comportamento de um participante exerce sobre o comportamento do outro.

Os resultados de nosso estudo em relação a essas características e suas influências na aprendizagem mostraram que o aluno espera ser ouvido e respeitado em suas opiniões e o ambiente de sala de aula deve ser bem aproveitado em relação à utilização do tempo e conteúdos ministrados ${ }^{(1)}$.

Masetto $^{(12)}$ analisou as características do professor que facilitam a aprendizagem, e a maioria dos alunos manifestou-se com as seguintes opiniões:

"coerência entre discurso e ação; segurança, abertura à crítica

e às propostas dos alunos, capacidade de diálogo; competência específica em sua área de conhecimentos; competência didática; clareza e objetividade na transmissão de 
informações; preocupação com o aluno e seus interesses; incentivo à participação; capacidade de coordenação de atividades; relacionamento acessível e paixão pela docência."

Ressaltando o aspecto de considerarmos as opiniões dos alunos, encontramos pesquisas mostrando o que é mais satisfatório em sala de aula, e a resposta com mais freqüência mencionada foi a respeito da qualidade das relações humanas, na qual os alunos destacam os professores que dão atenção, escutam, são honestos, abertos, entendem e respeitam o outro ${ }^{(13)}$.

Resultados semelhantes foram encontrados em nossos estudos, quando os alunos citam que a boa dinâmica em sala de aula, a boa comunicação professor-aluno e um conteúdo relevante são fatores facilitadores da interação $^{(1,14)}$.

A relação professor-aluno é a base de toda reflexão sobre educação, que com o outro se desenvolve com dimensões de simpatia e oposição e estas não são de modo algum contraditórias, mas, complementares. Só duas posições contrárias poderão dar ao homem sua significação total, pois sua procura por autenticidade define-se na busca da relação com o outro ${ }^{(15)}$.

Perrenoud $^{(16)}$ afirma que o conflito faz parte da vida como expressão de uma capacidade de recusar e de divergir que está no princípio de nossa autonomia e da individualização de nossa relação com o mundo. O conflito salienta a lateralidade e evoca a autoridade, considerando normal que cada pessoa só fique relativamente tranqüila, diante desses fenômenos, graças a um trabalho interno que pode levar toda a vida, quando se supõe competências de auto-análise e diálogo com os próximos. 
Coexistir é sempre, de uma forma ou de outra, dialogar, evocar, invocar e ser do outro, recorrer ao outro e a si próprio. No amor e na amizade, há uma reciprocidade e um antagonismo que ligam e desligam os seus participantes na procura de uma unidade que os englobe. Amor e amizade têm, pois, um valor educativo muito grande ${ }^{(15)}$.

Rogers $^{(17)}$ afirma que o professor é um ser humano como outro qualquer, tem empatia, emoções e relaciona-se com o ambiente, de acordo com suas vivências anteriores, ressalta a importância da autenticidade do professor, nas relações, como um aspecto facilitador da aprendizagem, argumentando que o professor deve ser "congruente", isto é, ser a pessoa que é e ter consciência plena de suas atitudes. A congruência significa que ele se sente receptivo perante seus sentimentos reais e, pode, ainda, ser ampliada de modo a abranger a adequação entre experiência, consciência e comunicação.

O professor torna-se uma pessoa real nas relações com seus alunos, podendo mostrar-se entusiasmado com assuntos de que gosta e aborrecido com aqueles por que não tem predileção. Pode irritar-se, mas é igualmente capaz de ser sensível ou simpático. Por aceitar esses sentimentos, não tem necessidade de impô-los a seus alunos nem insiste para que reajam da mesma forma ${ }^{(17)}$.

A coerência entre o verbal e o não-verbal aparece nitidamente em nosso estudo, quando constatamos gestos do professor e alunos que acompanhavam e ilustravam a fala, corpos voltados para o outro, indicando interesse e participação, expressões faciais positivas como sorriso, meneio positivo da cabeça e levantamento de sobrancelhas ${ }^{(1)}$. 
Pereira $^{(18)}$ mostra como a pessoa descobre-se ao se ver, por exemplo, numa filmagem. A autora afirma que é uma descoberta de si mesma, inicia pela dificuldade em se perceber e dar sentido à sua comunicação não-verbal até a descoberta de um estilo próprio, representando um movimento de reconhecimento dos aspectos não-verbais e também se percebendo positiva ou negativamente nas interações.

Gaiarsa $^{(19)}$ apresenta a psicanálise das atitudes corporais, segundo Reich, que são gestos, caras e tons de voz, apresentados em pormenores, que têm efeitos sobre os outros e sobre nós mesmos. Alguns desses efeitos, nós "temos a intenção de", desejamos e ou queremos, mas outros igualmente contidos em nossas expressões, nós não queremos, não percebemos ou não aceitamos.

Com Reich, começamos a ampliar a noção de que o corpo fala tanto como a palavra, assim, o que dá sustentação, força e sentido ao verbal é, precisamente o rosto, o tom de voz, o gesto e posição, ou seja, o contexto não-verbal ${ }^{(19)}$.

Autores como Silva ${ }^{(11)}$ e Alves ${ }^{(20)}$ também nos mostram que o educador fala com o corpo, que é no corpo de cada educador e de cada educando que estão escritas as suas histórias, ainda, os comportamentos corporais funcionam como sons significativos que são socialmente reconhecidos e válidos.

Em uma situação interacional, todo comportamento tem valor de mensagem, ou seja, é comunicação, além disso, toda a comunicação é um compromisso, pois transmite uma informação e impõe um comportamento ${ }^{(21)}$.

Sabemos que os alunos esperam ser emissores e receptores em situação de igualdade com o professor, nos encontros em sala de aula, desejam poder participar ativamente das interações, pois são indivíduos com capacidade 
suficiente para perceberem aspectos positivos ou negativos, que proporcionem transformações nos processos de troca ${ }^{(1)}$.

\section{Os professores e a competência em comunicação}

A universidade é uma instituição com o compromisso catalisador do processo educacional que deve transformar os indivíduos, professores e alunos em cidadãos autônomos, adaptados à realidade e com competências adequadas à sua profissão. Precisa promover um ensino atualizado com rigor científico, capaz de romper as barreiras do ensino fragmentado e elitista, não adaptado a nossa realidade, pois sabemos que este produz profissionais despreparados ${ }^{(22)}$.

Peres, Leite e Kurcgant ${ }^{(23)}$ afirmam que o professor de Enfermagem deve ter um preparo adequado, isto é, uma competência profissional. Consideram que é no contexto histórico e social em que o homem vive que emergem as possibilidades ou impossibilidades, os modos e as alternativas de formação de sua identidade profissional, portanto, o indivíduo deve assumir o desafio de educar, analisando sua identidade profissional dentro de múltiplos cenários, em que são enfocadas suas características individuais, sua história de vida e suas relações sociais.

A universidade deve, portanto, preparar o professor e conscientizá-lo de seu papel de comunicador, como fundamental para o ensino da Enfermagem; mas, sua motivação é estritamente necessária na busca da competência.

Competência é a capacidade de fazer e fazer-se oportunidade. Inclui questionamento reconstrutivo como base inovadora por meio do conhecimento e como processo de formação do sujeito histórico capaz. O conhecimento é uma 
ferramenta importante da competência, mas não assegura uma ação competente, é a capacidade e a coragem para inovar, associada a outras habilidades cognitivas e comportamentais que configuram o perfil do indivíduo competente ${ }^{(24)}$.

Para Perrenoud ${ }^{(25)}$, competência é a capacidade de agir eficazmente em um determinado tipo de situação apoiada em conhecimentos, mas sem limitar-se a eles.

Demo $^{(26)}$, discutindo os conceitos de quantidade e qualidade, refere que a quantidade aponta para o horizonte da extensão, do ter, e a qualidade, para a dimensão da intensidade, profundidade, perfeição, sobretudo com participação e criação, afirmando que a qualidade está mais para o ser do que para o ter. O termo qualidade aplica-se mais propriamente à ação humana até o ponto de defini-lo como toque humano na quantidade ou na realidade como tal pela sua relação com a intensidade.

É evidente a contradição entre quantidade e qualidade enfrentada pelo professor de Enfermagem, pois este tem várias atividades burocráticas e administrativas a cumprir além de seu compromisso com o ensino, ficando, notadamente, difícil destacar o humano nesse indivíduo. Assim, parece-nos que poucos professores de Enfermagem conseguem equilibrar suas atividades profissionais, de acordo com as necessidades atuais do ensino.

Pinheiro e Rodrigues ${ }^{(27)}$ citam as resistências cristalizadas na metodologia tradicional como fatores dificultadores do processo ensino-aprendizagem, afirmando que a resistência em mudar atrapalha o desenvolvimento da iniciativa, a capacidade crítico-reflexiva e a responsabilidade pelo próprio aprendizado. 
Concluem que é preciso mudar os comportamentos assumidos na docência para que possam ocorrer transformações no ensino de Enfermagem.

É função da educação formar cidadãos livres e autônomos, sujeitos do processo educacional, professores e alunos identificados com seu novo papel de pesquisadores, em um mundo cada vez mais informacional e informatizado. Isso exige transformações radicais no campo da educação; será preciso reavaliar teorias e reinventar estratégias e práticas. À universidade, cabe investir na produção acadêmica de conhecimento novo e inovador, repensar aspectos teóricos e metodológicos e integrar efetivamente o ensino e a pesquisa, pois somente com a modernização radical do campo educacional, que vai da pesquisa acadêmica às estratégias políticas, a escola poderá cumprir sua função social, formar o cidadão autônomo, competente técnica e politicamente ${ }^{(28)}$.

Estamos falando de transformações complexas que, segundo De Domenico ${ }^{(29)}$, envolvem a estrutura de formação em seus diferentes níveis, isto é, a aplicação da competência de se saber pensar, aprender a aprender e intervir de modo inovador e ético sob diferentes condições operacionais.

Em relação às necessidades de mudanças na formação, o estudo de Magalhães ${ }^{(30)}$ mostra que estas foram, inicialmente, discutidas com a Reforma Curricular proposta em 1994, que compunha um projeto único, com caráter corporativista, desconsiderando o mercado de trabalho, preservando a unicidade nacional e sem flexibilização. A publicação da Lei de Diretrizes e Bases da Educação Nacional - LDB em 1996, segundo a autora, também, não trouxe aspectos inovadores no que diz respeito à flexibilização e qualificação do ensino. 
As Diretrizes Curriculares Nacionais do Curso de Graduação em Enfermagem ${ }^{(31)}$ apontam para a formação generalista do Bacharel em Enfermagem. Nesses documentos, as competências gerais a serem adquiridas como: atenção à saúde, tomada de decisões, comunicação, liderança, administração e gerenciamento estão somadas às competências e habilidades específicas que compreendem o desenvolvimento de competências técnicocientíficas, ético-políticas, sócioeducativas capazes de atender às necessidades sociais da saúde, assegurar a integralidade da atenção, a qualidade e humanização do atendimento do indivíduo, da família e dos diferentes grupos da comunidade ${ }^{(29)}$.

De Domenico ${ }^{(29)}$ afirma que, nessa configuração, permanecemos na cultura do "modelo único", tanto na perspectiva teórica como prática, reiterando que sem autoria, sem espaço de criação, sem identidade, estamos num distanciamento das macropolíticas, cujas repercussões prenunciam despreparo e inserção periférica nos mundos da formação e do trabalho.

Nesta linha de pensamento, encontramos os estudos de Ide e Chaves ${ }^{(32)}$, Ângelo ${ }^{(33)}$, Bagnato ${ }^{(34)}$, Ern e Backes ${ }^{(35)}$, explicitando a ausência da coerência entre as metodologias de ensino empregadas e a necessidade de desenvolvimento de competências e habilidades que possam assegurar ao aluno a expressão de seus desejos e os referenciais da profissão

Em nossa busca na literatura, percebemos a importância da comunicação para o professor, especialmente, o professor da Enfermagem. Na Enfermagem, muitas pessoas estudam a importância da comunicação nas relações 


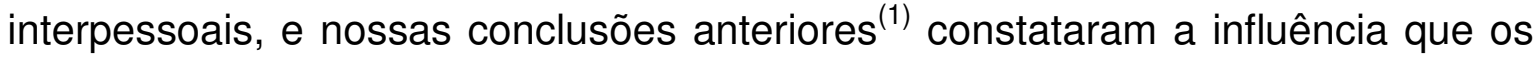
comportamentos dos professores têm no ensino desta profissão.

Os enfermeiros pouco têm publicado, especificamente, sobre o ensino de comunicação, situação amplamente discutida no estudo de Sandoval ${ }^{(36)}$, que pesquisou vinte teses, nas quais a comunicação era apresentada como tema central, afirmando que:

“...embora a universidade seja, também, palco da prática profissional do enfermeiro, o que predomina é o discurso sobre a prática assistencial. Apenas uma tese enfatizou a formação, o ensino da comunicação em Enfermagem, vale ressaltar que mesmo esta, se constitui em um ensino voltado para a comunicação na assistência de Enfermagem".

Neste sentido, a finalidade deste estudo é percorrer os caminhos da competência em comunicação para ensino da Enfermagem, por acreditar em sua influência para a formação do enfermeiro, como indivíduo social, ético e político.

Entendendo que apreender o processo comunicativo é fundamental para o ensino e o aprendizado da Enfermagem, buscamos, neste estudo, explorar os referenciais de competência comunicativa de especialistas da área, atuantes no ensino, bem como propor bases teórico-metodológicas que possam contribuir para o aprendizado da comunicação interpessoal, indicando caminhos possíveis para a qualidade no ensino da Enfermagem. 
Diante do exposto, temos como objetivos deste estudo:

Caracterizar referenciais de competências comunicativas interpessoais para o ensino da Enfermagem;

Propor bases teórico-metodológicas para o aprendizado da comunicação interpessoal em Enfermagem. 
2 REFERENCIAL TEÓRICO E METODOLÓGICO 


\subsection{Referencial Teórico}

A questão do comportamento comunicativo do docente de Enfermagem tem sido objeto de nossa atenção, bem como a coerência verbal e não-verbal deste comportamento.

Neste estudo, as menções anteriores nos levam a relatar uma perspectiva ou orientação teórica que promova a compreensão da comunicação, como um processo de interação face a face, visto que nesse processo estão envolvidas tentativas de entender outro e de ser entendido por ele.

Pautados nestas reflexões, pretendemos utilizar os referenciais de Silva ${ }^{(11,37,38)}$ para a comunicação interpessoal, verbal e não-verbal.

A comunicação verbal é associada às palavras expressas, por meio da linguagem escrita ou falada. Quando interagimos verbalmente com alguém, estamos tentando nos expressar transmitindo, clarificando ou validando a compreensão de algo.

A comunicação não-verbal verifica-se na interação pessoa-pessoa, exceto as palavras por elas mesmas, sua função é complementar, contradizer e substituir a comunicação verbal, além de demonstrar sentimentos. Pode também ser definida como toda informação obtida por meio de gestos, posturas, expressões faciais, orientações do corpo, singularidades somáticas naturais ou artificiais, organização dos objetos no espaço e até pela relação de distância mantida entre os indivíduos. 
A premissa básica da comunicação não-verbal é que o indivíduo participa simultaneamente de duas dimensões existenciais, decorrentes de dois modos de se relacionar com o mundo: uma verbal que the confere um estatuto psicolingüístico e outra não-verbal, com um estatuto psicobiológico ${ }^{(37)}$.

Na comunicação verbal, há um processo de exteriorização do ser social, ao passo que na comunicação não-verbal observamos um processo de exteriorização do ser psicológico ${ }^{(11)}$.

Silva ${ }^{(11,37,38)}$ subdivide os sinais não-verbais em seis itens, descritos a seguir:

Paralinguagem: qualquer som produzido pelo aparelho fonador que não faça parte do sistema sonoro da língua usada. Estes sinais são fornecidos pelo ritmo da voz, intensidade, entonação, grunhidos, ruídos vocais de hesitação, tosses provocadas por tensão, suspiro, etc.

Cinésica: a linguagem do corpo, ou seja, os seus movimentos, desde os gestos manuais, movimentos dos membros, meneios de cabeça até expressões mais sutis, como as faciais.

Proxêmica: o uso que o homem faz do espaço, como produto cultural específico, como a distância mantida entre os participantes de uma interação.

Tacêsica: tudo que envolve a comunicação tátil como pressão exercida, local onde se toca, tempo de contato, forma de aproximação, idade e sexo dos comunicadores, sendo relacionada com o espaço pessoal, a cultura dos comunicadores e as expectativas de relacionamento. 
Características físicas: são a forma e a aparência de um corpo que transmitem informações sobre faixa etária, sexo, origem étnica, social, estado de saúde, etc. Os objetos utilizados pela pessoa também são sinais de seu autoconceito e das relações mantidas.

Fatores do meio ambiente: são as disposições dos objetos no espaço e as características do próprio espaço como cor, forma e tamanho.

Silva ${ }^{(11)}$ destaca a importância da aprendizagem da comunicação nãoverbal para que possamos estabelecer relacionamentos interpessoais efetivos em todos os níveis de nossa vida e aponta alguns fatores que podem interferir na percepção desta comunicação como, por exemplo:

- a motivação: fator fundamental para adquirirmos habilidade na comunicação não-verbal, pois implica querer tornar consciente muito da linguagem inconsciente. A motivação aumenta, conforme percebemos a importância dessa habilidade na vida pessoal e profissional.

- emoções e expectativas: a maioria dos sinais não-verbais permite múltiplas interpretações, assim, sentimentos positivos como alegria e interesse nos deixam mais abertos à leitura do não-verbal, os sentimentos negativos, tristeza e raiva, nos tornam mais voltados para dentro, dificultando a identificação do não-verbal do outro;

- estereótipos e experiências anteriores: fatores que limitam nossa visão específica das coisas e do mundo, influenciando nossa percepção, idéias e sentimentos. Os estereótipos diminuem nossa percepção do contexto e fazem com que nossos mecanismos de projeção floresçam; 
- reconhecimento dos sinais: desenvolver a capacidade de reconhecimento de sinais de forma consciente é a base para a validação do que acontece nas interações;

- conhecimento prévio do emissor: quanto mais conhecemos alguém, mais sabemos sobre o significado dos sinais que emite;

- tempo do estímulo apresentado: quanto mais tempo estivermos expostos ao estímulo, melhor será nossa percepção e maiores serão nossas chances de decodificação correta dos sinais emitidos;

- limitações físicas: de tato, visão, audição, etc.;

- limitações fisiológicas: a ausência de integridade dos órgãos dos sentidos, alterações metabólicas, cansaço, dor, etc., limitam a leitura do não-verbal;

- ruídos: a quantidade de interferência que está ocorrendo no momento e na situação de interação, pode alterar a leitura do não-verbal;

Como realizamos o estudo no campo do ensino da Enfermagem, utilizamos, também, como referencial as premissas teóricas básicas colocadas por Silva ${ }^{(37,38)}$ em programas de treinamento para analisar a percepção da comunicação não-verbal, que são:

1므 a Enfermagem é um processo interpessoal;

$2^{\underline{a}} \quad$ a comunicação é um processo de interação simbólico-complexo;

3 as signos não-verbais envolvem comportamentos corporais, espaciais e locais; 
$4^{\mathrm{a}}$ os numerosos comportamentos não-verbais numa mensagem são inter-relacionados;

$5^{\mathrm{a}}$ os sinais não-verbais servem a várias funções da interação, a saber: demonstração de sentimentos, complementação do verbal, contradição do verbal e substituição do verbal;

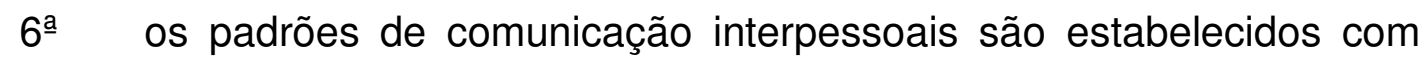
base nas necessidades interpessoais, que envolvem emoções e papéis sociais;

$7^{\mathrm{a}}$ a comunicação interpessoal implica a apresentação do eu a outros e sua meta é o maior entendimento entre os comunicadores envolvidos no processo;

$8^{\mathrm{a}} \quad$ o enfermeiro não pode negar ou ignorar a dimensão do não-verbal no desempenho de suas atividades.

Com base no referencial teórico mencionado, pretendemos abordar a importância da comunicação interpessoal, verbal e não-verbal, com seus diversos enfoques para o ensino da Enfermagem. 


\subsection{Referencial Metodológico}

\section{Tipo de Estudo}

É um estudo exploratório com abordagem qualitativa, em que foram entrevistados professores de Enfermagem que se dedicam ao estudo e pesquisa de comunicação em Enfermagem em sua trajetória profissional.

$\mathrm{Na}$ busca da compreensão dos caminhos que os levaram a adquirir competências comunicativas, que podem auxiliar no ensino da comunicação interpessoal na Enfermagem, optamos pela pesquisa qualitativa já que esta, segundo Minayo ${ }^{(39)}$, se preocupa com um nível de realidade que não pode ser quantificado, isto é, trabalha com um universo que corresponde a um espaço mais profundo das relações, dos processos e fenômenos que não podem ser reduzidos à operacionalização de variáveis.

\section{Local do Estudo}

Este estudo foi feito em Universidades brasileiras, públicas e privadas, por serem os locais de origem ou de atuação dos professores que desenvolvem as competências comunicativas, como instrumento no ensino da Enfermagem.

\section{Sujeitos do estudo}

Para realização do estudo proposto, entrevistamos 13 professores com experiência acumulada em atividades de ensino e pesquisa de comunicação em Enfermagem, destacando e localizando-os por meio de um levantamento de publicações e referências na área de comunicação em Enfermagem em nível 
nacional e internacional, nos últimos dez anos. Este levantamento de dados foi realizado nas bases de dados Dedalus (Banco de dados bibliográficos da Universidade de São Paulo), Lilacs e Medline.

Acrescentamos que todos os professores entrevistados possuem titulação mínima de doutor.

\section{Procedimentos de Coleta de Dados}

Inicialmente, o projeto de pesquisa foi submetido e aprovado pelo Comitê de Ética em Pesquisa da Faculdade de Medicina da UNESP- Botucatu em 4 de fevereiro de 2002 (Anexo I), a partir do qual iniciamos os procedimentos para a coleta de dados.

A validação das questões norteadoras do estudo foi feita por meio de uma entrevista gravada com uma Enfermeira, especialista em comunicação, que contribuiu com críticas e sugestões. Os dados do pré-teste não estão incluídos nos resultados da pesquisa.

Dos dezesseis docentes selecionados de acordo com os critérios estabelecidos, convidados a participar do estudo, 13 aceitaram fazer parte após serem contatados, pessoalmente, por telefone e ou e-mail, por meio dos quais explicitamos o projeto de pesquisa e seus objetivos. A partir da aceitação, foi agendada uma entrevista gravada e foi assinado o Termo de Consentimento Livre e Esclarecido para a realização do estudo (Anexo II).

As entrevistas ocorreram em locais escolhidos pelos entrevistados, a maior parte delas nas Escolas de Enfermagem de origem dos sujeitos do estudo. Cabe 
ressaltar que cinco docentes enviaram suas entrevistas por email, por motivo de distância geográfica e ou impossibilidade de conciliar o agendamento.

Durante as entrevistas, foram apresentadas as seguintes questões norteadoras que visavam orientar os entrevistados e promover uma ampliação e aprofundamento da comunicação:

1. O que é uma comunicação competente e ou eficaz?

2. Quais os mais importantes referenciais de competências comunicativas para você?

3. Como você expressa sua competência comunicativa?

4. Como você desenvolveu esta competência?

5. O que você propõe para o ensino de comunicação hoje?

6. Como você acompanha essa progressão de competência no aluno?

7. O que você ganha com sua competência em comunicação?

Os dados obtidos com a população por meio das entrevistas foram gravados, transcritos em sua íntegra e, posteriormente, devolvidos aos sujeitos para ciência e para que os mesmos tivessem a oportunidade de corrigir e ou acrescentar quaisquer outros aspectos que julgassem necessários. Dois docentes retornaram a entrevista com sugestões de correções na transcrição.

Os dados foram coletados pela pesquisadora no período de agosto de 2003 a fevereiro de 2004, mas o agendamento das entrevistas com os docentes iniciou-se no mês de abril de 2003. 


\section{Tratamento dos Dados}

A análise dos resultados das entrevistas foi feita, segundo a proposta de Análise de Conteúdo de Bardin ${ }^{(40)}$ que define a análise de conteúdo como:

“um conjunto de técnicas de análise das comunicações visando obter, mediante procedimentos sistemáticos e objetivos de descrição do conteúdo das mensagens, indicadores, quantitativos ou não, que permitam a inferência de conhecimentos relativos às condições de produção/recepção (variáveis inferidas) destas mensagens".

O fundamento da especificidade da análise de conteúdo reside na articulação entre "a superfície dos textos, descrita e analisada (pelo menos alguns elementos característicos) e os fatores que determinam estas características, deduzidos logicamente ${ }^{(40)}$.

A análise de conteúdo trabalha as palavras e suas significações, procurando conhecer o que está por trás das palavras analisadas ${ }^{(40)}$.

A técnica é constituída por três fases: a pré-análise, a descrição analítica e a interpretação inferencial.

A pré-análise é a fase de organização do material e a sistematização de idéias iniciais em um plano de análise. Nesta fase, fizemos a transcrição das entrevistas na íntegra e uma leitura flutuante dos textos, tomando contato exaustivo com o material.

A seguir, na fase de descrição analítica, foram feitos o recorte e a escolha das unidades de registro, elegendo-as e codificando-as, mediante a convergência com o fenômeno. Desta forma, classificamos as unidades temáticas sob um título 
genérico, com base em um grupo de elementos, num processo chamado categorização ${ }^{(40)}$.

O critério para categorização pode ser semântico ou temático, quando agrupados todos os temas com o mesmo significado; léxico, que corresponde à classificação das palavras, segundo seu sentido, com emparelhamento dos sinônimos e dos sentidos próximos; sintático, que agrupa verbos e adjetivos; e expressivo, que classificam as diversas perturbações da fala.

Para Bardin ${ }^{(40)}$ :

"a categorização é uma operação de classificação de elementos constitutivos de um conjunto, por diferenciação e, seguidamente, por reagrupamento segundo o gênero (analogia), com critérios previamente definidos. As categorias são rubricas ou classes, as quais reúnem um grupo de elementos (unidades de registro, no caso da análise de conteúdo) sob um título genérico, agrupamento esse efetuado em razão dos caracteres comuns destes elementos".

A categorização é a simplificação dos dados brutos, é um processo de estruturação, dividido entre inventário (isolamento dos elementos) e classificação (repartição dos elementos, impondo uma organização das mensagens) que propiciam a passagem dos dados brutos para dados organizados.

A palavra categoria, em geral, refere-se a um conceito que abrange elementos ou aspectos com características comuns ou que se relacionam entre si. Essa palavra está ligada à idéia de classe ou série. As categorias são empregadas para se estabelecerem classificações, e trabalhar com categorias 
significa agrupar elementos, idéias ou expressões em torno de um conceito capaz de abranger tudo isso(40).

No tratamento dos resultados obtidos, na inferência e na interpretação, os dados são desvelados a fim de que sejam significativos e válidos, portanto, nesta fase, tendo à disposição os dados, compreendemos as propostas básicas dos referenciais e competências comunicativas interpessoais para o ensino da Enfermagem, apontadas por estudiosos da área. 
3 APRESENTAÇÃO DOS RESULTADOS E ANÁLISE dOS DADOS 


\subsection{OS SIGNIFICADOS DA COMUNICAÇÃO COMPETENTE}

É um processo interpessoal

Atinge o objetivo dos comunicadores

Pressupõe conhecimentos básicos de comunicação

Há consciência do verbal e do não-verbal na interação

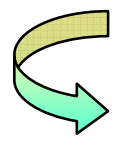

\section{Exige clareza e objetividade}

Promove autoconhecimento
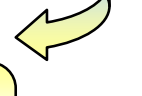


\section{1a categoria: É um processo interpessoal}

Para os entrevistados, comunicar-se competentemente pressupõe que as pessoas estejam preocupadas com a compreensão do outro e que as idéias sejam entendidas e compartilhadas.

O interesse pelo outro faz com que a mensagem seja transmitida com clareza e compreensão para com os envolvidos no processo comunicativo, o que confirma as falas de que a comunicação só é competente, quando é um processo interpessoal.

"É uma interação, aquela que partilha idéias, torna as idéias comuns; quando o outro me compreende e eu compreendo o outro." (E 2)

"É aquela onde existe a interação de duas pessoas e a mensagem é compreendida. $O$ que a gente percebe e que 0 Enfermeiro, muitas vezes, até se comunica com a equipe, mas a comunicação não é eficaz, porque quem está recebendo a mensagem não a está compreendendo..." (E 8)

"É aquela em que há uma disponibilidade para estar com o outro, compreender o outro, participar..., há uma fluidez da mensagem entre emissor e receptor." (E 10)

"É aquela em que ocorre uma ligação entre os seres humanos em relação às idéias e o alcance de sua finalidade." (E 12)

"É quando se decodifica a mensagem a partir da perspectiva do outro, só consigo imaginar competência em comunicação em uma relação interpessoal." (E 12)

Para Stefanelli(41), a comunicação é um processo de compreender e compartilhar mensagens enviadas e recebidas, e as próprias mensagens e o modo como se dá seu intercâmbio, exercem influência no comportamento das pessoas nele envolvidas, a curto, médio ou longo prazos. Esta mudança pode 
ocorrer no ambiente em que a comunicação é efetuada ou quando as pessoas estão isoladas, distantes umas das outras ou do contexto. Isto permite afirmar que estas se encontram, constantemente, envolvidas por um campo interacional.

$\mathrm{Na}$ relação com o paciente, a enfermeira comunica-se enquanto desempenha suas funções assistenciais, fazendo com que o paciente mova-se da dependência para a interdependência e independência, isto é, para o reconhecimento de suas potencialidades e aceitação de suas limitações, tornando-o participante ativo no seu cuidado ${ }^{(41)}$.

De Domenico ${ }^{(29)}$ considera que ao indivíduo em que é permitido interagir com sujeitos, objetos e situações, como forma produtora de aprendizado, este adquire habilidades e conhecimentos mais complexos, incluindo a capacidade de pensar criticamente, sendo esta, uma característica profissional bastante almejada pelo mercado de trabalho atual.

Satir(42) denomina a interação com o outro, como "fazer contato", explicitando que fazer contato não é um jogo, no qual se impõe um ponto de vista, mas, um jeito de lidar com e partilhar honestamente as questões e interesses humanos. É um modo de manter a integridade e alimentar o crescimento da auto-estima, fortalecendo, a longo prazo, o relacionamento consigo mesmo e com os outros.

Bachion $^{(43)}$ estudou amplamente o processo de comunicação interpessoal e encontrou nos estudos de comunicação verbal a impessoalidade, a diretividade, o autoritarismo, o desinteresse e o caráter eminentemente técnicoprofissional por parte da equipe de enfermagem, aliada à desatenção e 
percepção superficial das mensagens provindas do paciente. Em relação à comunicação verbal-escrita, havia evidências do uso de termos indevidos, nas anotações de enfermagem, relativos à descrição dos comportamentos observados, além da falta de anotações das ações executadas, e na comunicação não-verbal, o comportamento do profissional expressava distanciamento e pouca inclinação para a interação pessoal. A autora(43) considera necessária uma abordagem mais ampla da comunicação nas interações, considerando-a como um processo social prioritário, em que se dá também a assistência de Enfermagem.

Bachion $^{(43)}$ e Carvalho ${ }^{(44)}$ citam a contradição da comunicação representar um papel tão importante na Enfermagem e a pouca atenção dada ao desenvolvimento do domínio dos enfermeiros nesse aspecto.

A partir disso, visando a contribuir no aperfeiçoamento da prática profissional em Enfermagem e, em especial, no conhecimento do processo de comunicação, Bachion ${ }^{(43)}$ desenvolveu um estudo com alunos de graduação que, entre outros objetivos de interação, tinha como base um treinamento empregando técnicas facilitadoras e suprimindo aquelas consideradas bloqueadoras da comunicação, como as intimidatórias ou depreciativas.

Rios $^{(45)}$ cita que as condições para um trabalho competente estão na competência do profissional e na articulação dessa competência com os outros e com as circunstâncias, ou seja, uma pessoa não pode ser competente sozinha, a qualidade de seu trabalho não depende apenas dela, mas define-se na relação com os outros. 


\section{$2^{a}$ categoria: Atinge o objetivo dos comunicadores}

Os sujeitos da pesquisa afirmam que toda relação interpessoal tem um objetivo definido, mesmo que este não seja explicitado. Fundamentadas nesse objetivo, as pessoas conseguem se aproximar das outras utilizando meios para serem compreendidas e compreenderem. Os modos empregados para expressar a mensagem devem ser expressos com uma intenção clara por intermédio da transmissão de sinais e signos verbais e não-verbais que possam ser compreendidos pelo receptor.

Outro aspecto ressaltado pelos entrevistados, no que tange ao objetivo de uma relação interpessoal, é que este deve estar claro, sobretudo, numa relação profissional.

"É quando o outro me compreende e eu compreendo o outro." (E 2)

"É aquela em que eu consigo chegar no outro, as coisas fazem sentido, têm significado para o outro." (E 3)

"É aquela que atinge o objetivo dos comunicadores, ou seja, passa exatamente a idéia, a mensagem que o comunicador deseja. Por exemplo, quando estou me referindo a amizade, será que eu penso amizade igual ao outro? Ou amor, ou solidariedade? Até mesmo uma cor, quando eu falo azul, eu uso símbolos. Se me comunico usando símbolos, como eu vou ter certeza que esta simbologia vai ser entendida da mesma forma que eu? Nunca vai ser, mas a idéia é que a compreensão seja a mais próxima possível. Então quando eu envio uma mensagem, eu preciso mandar estes símbolos da forma mais clara possível e verificar, fazer a validação da comunicação." (E 6)

"É uma comunicação que alcança o objetivo que ela tem. Partindo do pressuposto que você tem que ter um objetivo num relacionamento, sobretudo, numa interação profissional, mesmo que este objetivo não seja explícito e negociado." (E 9) 
"É aquela em que o emissor e o receptor compreendem a mensagem enviada." (E 11)

"É aquele processo em que o emissor consegue expressar seu pensamento/ intenção o mais próximo possível do real e o receptor consegue captar com clareza aquilo que foi expresso. Há dificuldades a serem transpostas para que isso aconteça, pois quando eu quero expressar determinada idéia ou sentimento, eu exteriorizo um conjunto global de sinais/ signos verbais e não-verbais. Eu penso que o que eu gostaria de transmitir foi claramente expresso, mas nem sempre isso acontece." (E 13)

Estes relatos corroboram as afirmações de Silva(11), ao considerar que uma comunicação adequada é aquela apropriada a uma determinada situação, pessoa ou tempo e que atinge um objetivo definido.

No campo interacional, as pessoas percebem-se e partilham o significado de idéias, pensamentos e propósitos, modificando-os no processo de interação com os outros ${ }^{(41)}$.

Por meio da comunicação, podem ser definidos objetivos e metas a serem atingidos no cuidado e ensino de Enfermagem.

Stefanelli ${ }^{(41)}$ afirma que o enfermeiro deve ser um educador por excelência e educação é, sobretudo, comunicação, afirmação complementada por Rios ${ }^{(45)}$ quando explicita que o educador competente é comprometido com a construção de uma sociedade justa e democrática.

\section{3aㅡ categoria: Pressupõe conhecimentos básicos de comunicação}

Os sujeitos explicitam que deve haver a busca de conhecimento e o preparo do enfermeiro, como um requisito para a atuação na área. 
A comunicação é uma habilidade que pode ser adquirida, e a busca pelo conhecimento faz com que o indivíduo adquira e aprofunde conceitos de comunicação adequada e eficaz, que possam ser realmente terapêuticos no exercício do cuidar. Os sujeitos do estudo afirmam que esta busca pelo conhecimento promove a conscientização dos elementos envolvidos no processo comunicativo, que podem ser usados para viabilizar a comunicação.

Em conseqüência, os indivíduos implicados dominam as técnicas básicas de comunicação e esta competência possibilitar-Ihes-á seu uso em tempo e momento adequados.

"É quando eu tenho conhecimento básico de conceitos de comunicação, em geral, e humana, e, mais profundo, de comunicação terapêutica. Eu tenho que introjetar conceitos de comunicação adequada, eficaz e terapêutica para que eu possa ter competência em comunicação. É uma competência a ser adquirida." (E 2)

"É quando o profissional tem preparo e sabe o que está fazendo." (E 5)

"É quando o comunicador tem consciência de todos os elementos do processo de comunicação e de como eles funcionam..." (E 6)

"É quando o emissor tem conhecimento do que quer comunicar, domina as técnicas e os meios para esta comunicação." (E 12)

Nesta categoria, os sujeitos da pesquisa reafirmam a necessidade da aquisição de conhecimentos, também, ressaltada por autores como Perrenoud $^{(16,25)}$, quando afirma que não existem competências que não se apóiem em conhecimentos e estes são representações da realidade que construímos e armazenamos ao sabor de nossa experiência e formação, e 
Peres, Leite e Kurcgant ${ }^{(23)}$ explicitam a necessidade de um preparo adequado para o professor no processo educacional, ou seja, que todo o professor deve buscar a competência profissional.

Demo $^{(24)}$ define educação como o processo de formação da competência humana, com qualidade formal e política, tendo no conhecimento inovador sua principal alavanca. Para este autor, competência significa a "capacidade de fazer e fazer-se oportunidade. Inclui o questionamento reconstrutivo, como sua base inovadora por meio do conhecimento e como processo de formação do sujeito histórico capaz", prevalecendo, na educação, a definição de competência como processo de formação do sujeito histórico capaz de inovar, sobretudo de humanizar a inovação.

No que se refere ao cuidar na Enfermagem, percebemos que o uso consciente da comunicação precisa ser precedido pelo conhecimento das teorias e dos pressupostos básicos do processo comunicativo e de todos os elementos a ele pertinentes, afirmação corroborada por Stefanelli ${ }^{(41)}$ quando explicita que a enfermeira deve ter consciência das situações envolvidas no cuidar e conhecer como ocorre este processo.

Em seu estudo sobre comunicação interpessoal e ensino de algumas habilidades desejadas, Bachion ${ }^{(43)}$ afirma que na sua percepção e na de Carvalho $^{(44)}$ o profissional de Enfermagem comunica-se na prática apenas com habilidades inatas, isto é, sem o desenvolvimento das habilidades advindas da aprendizagem em seu processo de formação profissional. Bachion ${ }^{(43)}$ cita serem relevantes os indícios obtidos na literatura de que as dificuldades no 
desempenho e compreensão do processo de comunicação, iniciam-se na formação, tanto do profissional de Enfermagem como dos demais membros da equipe.

4ª categoria: Há consciência do verbal e do não-verbal na interação

Os entrevistados relatam a necessidade da atenção para as formas de expressão que estão envolvidas na comunicação, ressaltando a necessidade de considerar o outro, com suas diferenças, nas relações interpessoais.

A competência implica estar consciente de que emitimos e recebemos sinais/signos verbais e não-verbais em todo o decorrer do processo. $O$ uso consciente desse conhecimento faz com que se esteja atento ao outro para perceber o que ele deseja comunicar e até para constatar se a intenção comunicativa foi transmitida ou não. Baseando-se nessa conscientização, podemos reconhecer a individualidade e experiências anteriores, percebendo as reações do outro e os momentos em que se deve interromper ou manter determinada interação.

"O importante é o uso consciente que você faz do seu conhecimento de comunicação; isso é básico; ter consciência de quando você deixou de ser terapêutica para poder voltar no processo de amadurecimento e ajudar o outro a amadurecer."

(E 2)

"É quando se está atento ao verbal e não-verbal, ou seja, estar atento ao que o emissor diz e também ao que ele expressa para estar confirmando ou não o que ele está dizendo verbalmente."

(E 4) 
"É verificar, fazer a validação, ver se foi entendido ou não. Eu me comunico, não só de modo verbal, mas também com o nãoverbal. Nesta parte não-verbal, nós temos o retorno, confirmando ou não a mensagem, quer dizer, na medida em que eu me comunico, o não-verbal do receptor vai me enviando mensagens que podem ser coerentes ou não, ou até, me dando sinais de que a minha comunicação não está clara, está confusa, desinteressante." (E 6)

"O receptor vai receber minha comunicação global (verbal e nãoverbal) e atribuir significado a ela de acordo com suas experiências anteriores, em relação à minha pessoa ou a situações semelhantes." (E 13)

"É perceber as reações do outro e saber identificar os momentos em que eu devo ficar em silêncio e aqueles em que devo prosseguir." (E 13)

A comunicação humana é complexa e multidimensional e o processo dessa interação supõe, necessariamente, comunicação, mesmo que haja contradição entre estas dimensões. A comunicação sempre acontece, seja por meio de palavras ou por meios não-verbais, tais como gestos, postura corporal, posição, distância em relação aos outros, etc ${ }^{(4,11)}$.

O processo de interação humana é marcado por interferências ou reações, voluntárias ou involuntárias, intencionais ou não, isto é, as pessoas reagem às outras pessoas, com as quais entram em contato: comunicam-se, simpatizam e sentem atração, antipatizam e sentem aversão, aproximam-se, afastam-se, entram em conflito, competem, colaboram, desenvolvem afeto, etc ${ }^{(4)}$.

Neste sentido, Blondis e Jackson ${ }^{(46)}$ reiteram durante uma troca comunicativa, que nós usamos nossos sentidos, simultaneamente, num processo de enviar e receber mensagens e o modo como utilizamos os sentidos e interpretamos as mensagens, determinará nossas observações. Desta forma, 
precisamos monitorar nossos sentidos para produzir os gestos e palavras que pretendemos transmitir, e as reações do outro, para determinar como a mensagem foi recebida.

O uso efetivo dos sentidos assegura a percepção acurada da mensagem, pois, para aprender a comunicar-se adequadamente, cada indivíduo deve ter a capacidade de perceber o significado da mensagem e dos aspectos nela envolvidos, ou seja, se é comum aos comunicadores, como e quando as mensagens enviadas afetam as outras pessoas e, também, como seus próprios sentimentos atingem a comunicação que está ocorrendo ${ }^{(41)}$.

Birdwhistell $^{(47)}$, um pioneiro em pesquisa não-verbal, afirma que não é fácil isolar, separar as interações humanas em comportamentos verbais ou nãoverbais.

Portanto, ao enviarmos e recebermos mensagens, estamos também expressando e recebendo pensamentos e sentimentos, tanto de forma verbal como não-verbal.

\section{5aㅡ categoria: Exige clareza e objetividade}

Os sujeitos entrevistados expressam que a clareza e a objetividade são importantes para que a comunicação seja efetiva, isto é, uma comunicação ou informação deve ser passível de ser interpretada e decodificada. Sob este ponto de vista, as idéias devem ser organizadas para serem compreensíveis ao receptor. 
"É a capacidade de comunicar-se com atenção e intenção para que as mensagens possam ter um significado e para que sejam corretamente interpretadas e decodificadas." (E 1)

"É um conjunto de práticas objetivas, datadas, localizadas, produtoras de sentidos, significados e efeitos tanto em quem as emite como em quem as recebe." (E 7)

"É necessário que eu me expresse usando uma linguagem compreensível para o receptor e que as idéias sejam organizadas de forma clara e objetiva." (E 13)

Para Silva(11), a comunicação adequada é aquela que tenta diminuir conflitos e mal-entendidos, e o primeiro aspecto a ser considerado na comunicação verbal é a clareza, quanto àquilo que desejamos informar. Quando interagimos verbalmente com alguém, estamos tentando basicamente nos expressar, clarificar ou validar a compreensão de algo, pois, saber o que se pretende com a verbalização, auxilia em sua adequação.

Stefanelli ${ }^{(41)}$ apresenta técnicas de comunicação verbal, divididas em três grupos que são: expressão, clarificação e validação. Na técnica da expressão, recomenda o uso do silêncio, ouvir reflexivamente, verbalizar aceitação interesse, fazer perguntas, usar frases descritivas, manter o outro no mesmo assunto, colocar em foco a idéia principal, verbalizar dúvidas, dizer não, estimular a expressão de sentimentos subjacentes, usar terapeuticamente o humor, entre outros. Na clarificação, aponta para o estímulo de comparações, esclarecimento de termos incomuns e solicitar que o outro precise o agente da ação, escrevendo os eventos em seqüência. Na técnica de validação, recomenda a repetição da mensagem do outro e, ainda, a solicitar ao outro que repita o que você disse, resumindo o conteúdo da interação. 
A comunicação não-verbal não está associada às palavras e ocorre por meio de gestos, silêncio, expressão facial, postura corporal, etc.

Para Silva ${ }^{(11)}$, na interação face a face, os códigos de comunicação são audíveis, mas também visíveis e sensíveis, assim, comunicamo-nos com a linguagem verbal e com o corpo todo, inclusive, com objetos e adornos utilizados. Outros estudiosos da comunicação não-verbal, como Birdwhistell ${ }^{(47)}$, Davis ${ }^{(48)}$ e Gaiarsa $^{(19)}$ também consideram estas colocações.

Nas palavras de Gaiarsa ${ }^{(19)}$, percebemos o quanto nosso corpo pode comunicar, favorecendo ou dificultando nossas intenções:

\begin{abstract}
"A imensa maioria das pessoas acredita que ao falar, 0 importante é o rosário de palavras, que este rosário diz exatamente o que elas pretendem e, implicitamente, que a música da voz e a dança dos gestos estarão completamente de acordo ou integradas às palavras ditas. Se fosse assim, a pessoa não estranharia nada, nem a própria figura vista num teipe, nem a própria voz e suas inflexões ouvidas num gravador, muito menos, estranharia as reações dos outros ao que ela disse. Nossa estranheza ante nossa imagem e nossa voz mede exatamente a distância ou a diferença entre o que pretendemos comunicar, e o que o outro recebe ou entende."
\end{abstract}

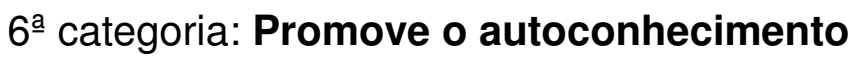

Nesta categoria, os sujeitos relatam o crescimento pessoal advindo dos conhecimentos adquiridos em comunicação. 
Os indivíduos crescem apoiados nas interações, conhecem e percebem suas próprias reações, conhecem os outros e permitem que estes os conheçam. Este crescimento leva a uma comunicação competente porque é produzido por abertura de ambas as partes.

Os entrevistados traduzem o autoconhecimento como uma revisão e avaliação da prática comunicativa, isto é, percebem-se conscientes como pessoas e profissionais nas interações que estabelecem.

"É uma interação que faz crescer, é eu me conhecer muito bem e permitir que o outro me conheça; de nada adianta eu me conhecer muito bem e me enclausurar para evitar que os outros me manipulem. É desta interação que a gente cresce, só por meio de uma comunicação competente, eficaz, eu me abro cada vez mais para o outro e permito que o outro me conheça." (E 2)

"Eu recomendo para as alunas, para as famílias, para todo mundo com quem eu trabalho: reserve um período do dia, cinco minutos, dois minutos, que seja, para pensar no que expressou, no que falou. Como foi a interação com as outras pessoas? Se foi benéfico, ou não? Se você interagiu, você fez, você pensou, você está aprendendo a ver quem você é e isso vai ter influência na sua comunicação futura." (E 2)

"É quando me comunico comigo mesmo, tentando visualizar minhas próprias respostas a esta prática comunicativa que eu estou querendo realizar; estar em estado comunicante... e isso implica em diálogo." (E 7)

"É quando fazemos uma revisão do que somos enquanto pessoas e profissionais, colocamos a consciência do que somos como raiz fundamental, que dá o sentido profundo da comunicação." (E 7)

Uma das funções da comunicação citada e valorizada por Stefanelli ${ }^{(41)}$ é a de "conhecer a si mesmo". A autora afirma que a enfermeira precisa conhecer-se bem, isso é, como pensa, sente, age e reage diante dos fatos, o que lhe facilitará, 
em grande parte o conhecimento do outro e a compreensão do por quê ela reage de maneiras diversas a um mesmo estímulo. Quando a pessoa conhece a si mesma, sabe que pode ser afetada pelo comportamento do outro e que seu comportamento também poderá afetar o outro.

Moscovici(4) aponta a percepção e a habilidade, como dois componentes importantes da competência interpessoal, mostrando que o processo de percepção precisa de treinamento e este exige coragem e disponibilidade psicológica para receber feedback. Isto significa um longo processo de crescimento pessoal, abrangendo autopercepção, autoconscientização e autoaceitação como pré-requisitos de possibilidades de percepção mais realística dos outros e da situação interpessoal, pois o autoconhecimento só pode ser obtido com a ajuda dos outros, por meio de feedback.

A respeito do processo de percepção de um indivíduo em relação a si mesmo e aos outros, encontramos a representação gráfica de áreas da

personalidade chamada Janela de Johari, idealizada por Luft e Ingham ${ }^{(49)}$, que permite a percepção do fluxo de informações de duas fontes, eu e os outros, bem como as tendências individuais que facilitam ou dificultam a direção e a extensão deste fluxo.

Se o indivíduo tem percepção mais acurada de si, pode também ter percepção acurada da situação interpessoal, sendo este o primeiro passo para agir de forma acurada e realística ${ }^{(4)}$. 
Pereira $^{(18)}$ encontrou resultados significativos de autoconhecimento ao trabalhar com Enfermeiras de Educação Continuada, concluiu que a filmagem usada no estudo permitiu à enfermeira uma visualização de si mesma em situação de interação, levando ao desencadeamento de percepções e ao resgate de significados, trazendo a vivência e o aprendizado de outras interações e a construção de um processo interpretativo. Como resultado, a enfermeira faz um diálogo consigo mesma, lida com esses significados, seleciona, avalia, reagrupa e, à luz da situação vivenciada age.

\section{$7^{\text {a }}$ categoria: Possibilita uma vida mais autêntica}

Nesta categoria, os sujeitos mostram possibilidades de ganho com base na conscientização dessa ligação entre os seres humanos.

ganho que possibilita uma vida mais autêntica advém do crescimento, autoconhecimento e desenvolvimento competente das habilidades comunicativas. Os entrevistados ressaltam que a assimilação de conhecimentos em comunicação deve ser aplicada no cotidiano dos indivíduos, em relacionamentos pessoais, familiares, sociais e profissionais. Suas falas deixam claro que existem limitações e dificuldades nesta aplicação, mas que viver o diaa-dia experienciando conhecimentos adquiridos, possibilita uma vida mais autêntica e conseqüentemente, um viver bem, podendo-se entender como a tranqüilidade de quem está consciente de estar em crescimento.

"É quando eu me abro cada vez mais para o outro, pois só se atinge competência na comunicação quando consegue assimilar conhecimentos e habilidades na vida diária, quando eu digo vida diária, eu quero dizer, relacionamento mãe e filho, namorado, 
com pai, mãe, genro, nora ou sogra, você faz disso teu lema de vida, você não fica pensando em usar esta ou aquela regra, não é regra, são pistas, dicas, indícios de um caminho de comunicação eficaz que a gente vai incorporando. Eu procuro aplicar meu conhecimento de comunicação em todos os momentos da minha vida reconhecendo minhas dificuldades e minhas limitações." (E 2)

"É uma estratégia que possibilita a promoção do viver bem." (E 7)

"É parte integrante da vida, inerente a uma vida autêntica." (E 12)

Educador autêntico é educador congruente. Concordamos com Rogers ${ }^{(17)}$ quando afirma que ser congruente é ter consciência plena das atitudes que assume, significa sentir-se receptivo, perante seus sentimentos reais e, ainda, ter a adequação entre experiência, consciência e comunicação. O professor torna-se, então, uma pessoa real nas relações com os seus alunos, pode mostrar-se entusiasmado com assuntos de que gosta e aborrecido com aqueles por que não tem predileção. Pode irritar-se, mas é igualmente capaz de ser sensível ou simpático, aceita estes sentimentos como seus e não tem necessidade de impôlos a seus alunos nem insiste para que reajam da mesma forma.

O professor é um ser humano como outro qualquer, tem empatia, emoções e relaciona-se com o ambiente, de acordo com suas vivências anteriores. Não é a encarnação abstrata de uma exigência curricular ou um canal estéril por meio do qual o saber passa de geração em geração ${ }^{(17)}$.

A respeito deste aspecto, $\operatorname{Rios}^{(50)}$ afirma que devemos ir além da definição de "ser humano" como um ser racional, mas, sim, que o ser humano é um ser simbólico significando que racionalidade não é algo isolado, porém algo 
estreitamente articulado a outras capacidades, outros instrumentos que o homem tem para interferir na realidade e transformá-la. Acrescenta, ainda, que a imaginação e a sensibilidade são constituintes da humanidade do homem e não podem ser desconsideradas quando se fala em sua realização. Ao falar em competência, aponta para um movimento em direção à beleza, aqui entendida como algo que se aproxima do que se necessita concretamente para o bem social e coletivo.

Nas palavras de Satir ${ }^{(42)}$, percebemos os ganhos deste envolvimento com a competência comunicativa:

"Quanto mais amplo e completo for o contato que temos conosco e com o outro, mais nos sentiremos amados, valorizados e saudáveis, e saberemos solucionar nossos problemas." 


\subsection{OS REFERENCIAIS DE COMPETÊNCIA COMUNICATIVA}

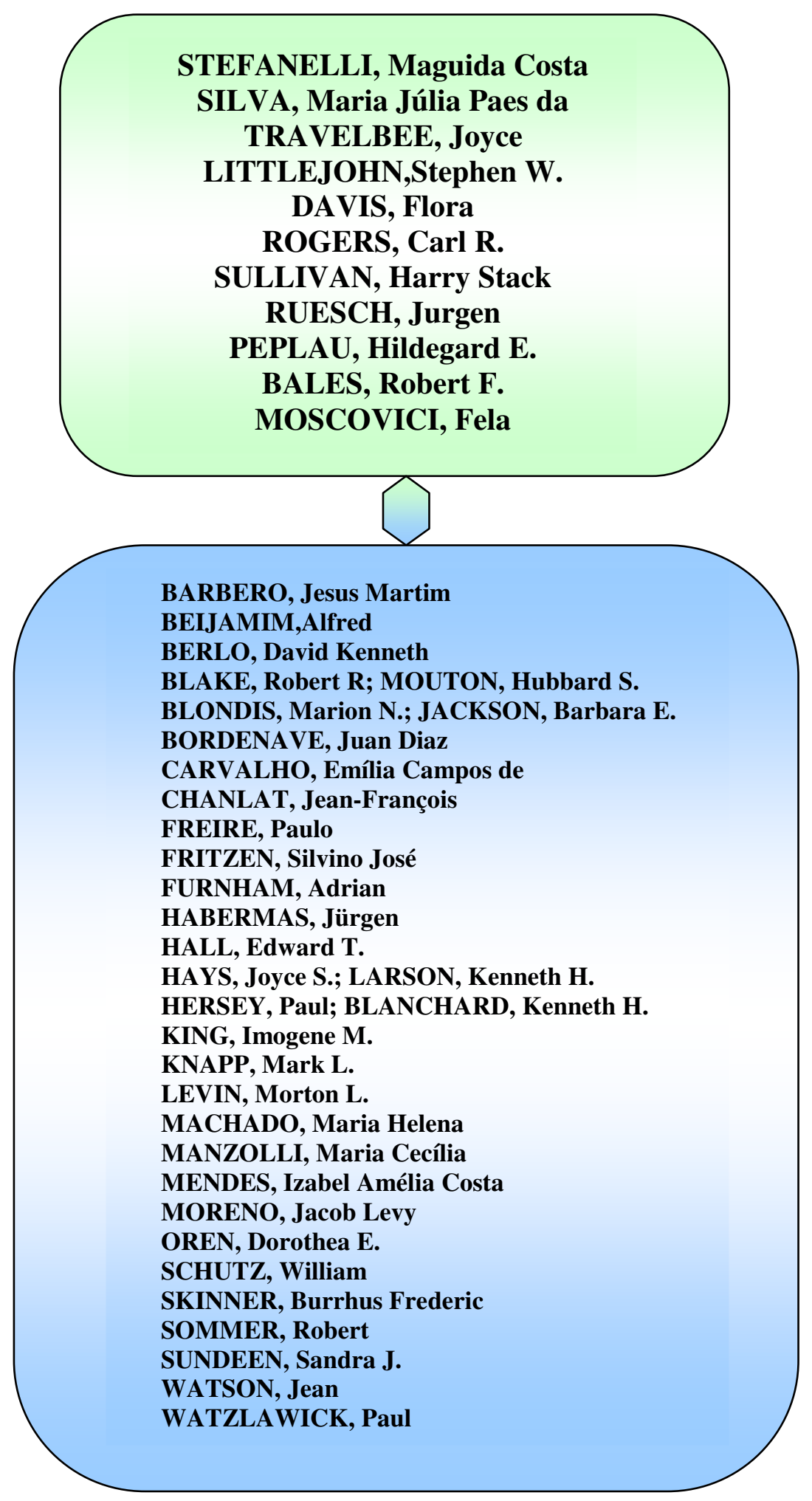

Esquema 2. Os referenciais de competência comunicativa 
Os enfermeiros pesquisados indicaram os autores que utilizam como referenciais, incorporados com base em suas experiências profissionais, que os instrumentalizam e Ihes permitem avançar, aqueles que deixam claro que a pessoa precisa ter competência em comunicação, ter preparo e saber o que está fazendo.

Diante do exposto, apresentamos, primeiro, os autores citados duas vezes, ou mais, entendendo que são os mais aceitos como referencial pelos especialistas em comunicação na Enfermagem e, em seguida, apresentamos os referenciais que tiveram uma única citação por parte dos sujeitos do estudo.

\section{Referenciais teóricos de comunicação, organizados por ordem decrescente de citações}

\section{STEFANELLI, Maguida Costa}

Afirma que a capacidade interpessoal do enfermeiro no cuidado de Enfermagem é um fator significativo para o bem-estar do paciente e esta capacidade pode ser adquirida, também, pelo uso de estratégias de comunicação terapêutica $^{(41)}$.

Para a autora, a comunicação permeia toda a ação do enfermeiro e, além de ter consciência desse fato, o profissional precisa conhecer como se dá o processo comunicativo e todos os elementos a ele pertinentes, bem como utilizálos em sua prática, para que o paciente o considere um elemento de ajuda, um 
outro ser humano, capaz e eficiente, com quem ele pode interagir e partilhar suas idéias. A comunicação é um processo de compreender e compartilhar mensagens enviadas e recebidas. Isso permite entender que as pessoas encontram-se constantemente envolvidas por um campo interacional. Aborda as funções, as formas, os ruídos, as variáveis e os modos de comunicação, e explicita referenciais teóricos para a comunicação terapêutica e propõe instrumentos para este ensino ${ }^{(41)}$.

\section{SILVA, Maria Júlia Paes da}

Aborda comunicação verbal e, sobretudo, a não-verbal com suas várias formas de se manifestar. Enfoca a comunicação nas relações interpessoais em saúde e seus reflexos sobre as relações de grupos e de trabalho.

Centraliza seus estudos de comunicação na área da saúde porque, segundo ela, o profissional de saúde tem como base do seu trabalho, as relações humanas e todo o processo comunicativo nelas inserido, como a escrita, a fala, as expressões faciais, a audição e o tato. Entende como comunicação adequada, a comunicação que tenta diminuir conflitos, mal-entendidos e atingir objetivos definidos para a solução dos problemas detectados. Define comunicação verbal e não-verbal com seus elementos, finalidades, formas e funções. Apresenta um programa de aprendizagem e treinamento em comunicação não-verbal, incluindo a percepção nas relações humanas. Aborda, também, reflexões sobre a comunicação nas relações de grupos e de trabalho, incluindo elementos de 
análise dos grupos, dicas para um ambiente mais harmônico e necessidades interpessoais dos elementos de um grupo $^{(11,37,38)}$.

\section{TRAVELBEE, Joyce}

Enfermagem é um processo interpessoal no qual o enfermeiro assiste um indivíduo, família ou comunidade para prevenir ou lutar na experiência de doença e sofrimento e, se necessário, achar um significado em tais experiências. A proposição principal é que a Enfermagem realiza-se por meio do relacionamento pessoa a pessoa, sendo a comunicação, o processo que possibilita seu estabelecimento $^{(41)}$.

Os enfermeiros que se comprometem nesta relação compreendem o vínculo pessoal e agem como facilitadores, mostrando-se interessados em ajudar os outros a se ajudarem. Na relação de ajuda, é imprescindível infundir no outro o sentimento de confiança para que ele consiga se expor e ter esperanças de se beneficiar, assim, o profissional consegue abrir novas vias de comunicação, sendo sensível às oportunidades de quando falar, o que falar, quando calar e quando mostrar seu interesse por meio da comunicação ${ }^{(51)}$.

Afirma que a intervenção do enfermeiro é inadequada ou nula se houver uma interpretação incorreta do resultado de uma comunicação, reforçando a necessidade de verificar com o outro o significado de sua mensagem, a fim de ajudá-lo a comunicar-se, estabelecendo relações significativas ${ }^{(52)}$. 


\section{LITTLEJOHN, Stephen W.}

Um clássico da literatura em comunicação humana aborda o interacionismo simbólico, seus fundamentos e suas proposições teóricas básicas que confirmam a comunicação como um processo de interação simbólica. Aborda a teoria dos signos, incluindo a codificação verbal e não-verbal e, ainda, as teorias de significado, pensamento, informação, persuasão e mudança.

Nos contextos de comunicação, afirma que a comunicação interpessoal no contexto da interação face a face consiste em eventos de comunicação oral e direta, incluindo necessidades de comunicação como as interpessoais de inclusão, controle e afeição e como estas constituem um conjunto de áreas de comportamento interpessoal para a previsão e explicação de fenômenos interpessoais, abordando, também, a auto-apresentação, a revelação, a compreensão, a percepção, a atração interpessoal e o conflito social.

Nas teorias de comunicação em pequeno grupo, aborda a natureza dos grupos, teorias de manutenção e motivação de grupo, as fases de desenvolvimento dos grupos e a teoria de efeitos interpessoais em grupos.

$\mathrm{Na}$ obra deste autor encontramos, também as teorias de organização humana, de comunicação de massa, dos sistemas gerais e cibernética e, finalmente, uma abordagem sobre comunicação como uma integração

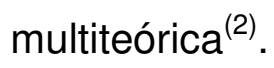




\section{DAVIS, Flora}

Aborda as diferentes dimensões da comunicação não-verbal, ressaltando que grande parte da comunicação humana se passa num nível em que a importância das palavras é apenas indireta.

Afirma que a sensibilidade humana desenvolve-se por meio do relacionamento interpessoal e que as emoções são transmitidas e compartilhadas, quando não tateadas de forma não-verbal. O corpo é uma forma de manifestação dos elementos não-verbais, afirmando que ele a troca de mensagens verbais seria impossível ${ }^{(48)}$.

\section{ROGERS, Carl R.}

O autor dá ênfase às relações interpessoais e ao crescimento que delas resulta, centrado no desenvolvimento do indivíduo e em seus processos de construção e organização pessoal da realidade. Cita o relacionamento interpessoal como facilitador da aprendizagem, em que facilitar a aprendizagem significa libertar a curiosidade, permitindo que as pessoas assumam o encargo de seguir novas direções, de acordo com seus próprios interesses, desencadeando o senso de pesquisa, indagação e análise, reconhecendo que tudo se acha em processo de mudança ${ }^{(1)}$.

Ressalta que os verdadeiros relacionamentos interpessoais são profundamente capazes de suscitar crescimento. Valoriza a capacidade de ouvir, sensitivamente, a dor, a alegria, o temor, a irritação, a perplexidade, a angústia, enfim, a determinação e a coragem de ser, manifestados por outra pessoa. 
Escreve que a autenticidade própria gera autenticidade no outro e uma aproximação recíproca na relação eu-tu(53).

Em seu estudo sobre a autenticidade, o autor afirma que a aprendizagem pode ser facilitada se o professor for congruente, isso implica que ele seja uma pessoa real, isto é, que tenha consciência plena das atitudes que assume, e que talvez importe menos que este professor cumpra todo o programa estabelecido ou utilize métodos audiovisuais mais apropriados, o que mais importa é que ele seja congruente, autêntico em suas relações com os alunos ${ }^{(17)}$.

Estabelece o termo congruência como o termo, a que recorremos para indicar uma correspondência mais adequada entre experiência e consciência. Este pode ser ampliado de modo a abranger a adequação entre experiência, consciência e comunicação ${ }^{(17)}$.

Admite como verdadeira a seguinte relação hipotética: quanto maior for a congruência da experiência, da consciência e da comunicação por parte de um indivíduo, mais a relação originada implicará uma tendência para uma comunicação recíproca, caracterizada por uma crescente congruência, tendência para uma compreensão mútua, melhoria da adaptação psicológica e do funcionamento de ambas as partes e satisfação recíproca na relação.

Inversamente, quanto maior for a incongruência comunicada da experiência e da consciência, mais as relações assim originadas envolvem: comunicações posteriores com as mesmas características, desintegração da compreensão adequada, funcionamento e adaptação psicológica menos adaptadas em ambas as partes e insatisfação recíproca na relação ${ }^{(17)}$. 


\section{SULLIVAN, Harry Stack}

O objetivo do estudo deste autor é voltado para uma terapia efetiva, na qual a pessoa é resultado de um processo social decorrente da experiência com outras pessoas significativas, desde o nascimento até a morte, portanto, só aprende e evolui se desenvolver interação com outra pessoa, que the é significativa. Afirma que não se pode estudar o ser humano isoladamente, pois suas experiências interpessoais de satisfação e de segurança devem ser consideradas, para isso a pessoa precisa experimentar sentimentos de aprovação, prestígio e proteção contra a ansiedade.

Acredita que a doença mental é resultante de falha no processo interpessoal ou de comunicação inadequada da pessoa com os outros, tendo como aspecto relevante em sua teoria, a crença no potencial do indivíduo para mudança e na adaptabilidade do ser humano para responder às pessoas e à cultura $^{(41)}$.

\section{RUESCH, Jurgen}

Considera a comunicação o princípio organizador da natureza que une um ser ao outro. Para ele, comunicação abrange todos os modelos pelos quais uma pessoa pode afetar a outra, de modo verbal e não-verbal.

O ser humano mantém-se em interação com o outro por meio da comunicação, sendo funções da comunicação: receber, transmitir e reter informação, reconstruir o passado, antecipar fatos futuros e trabalhar com a 
informação existente, com o propósito de perceber novos elementos que exercem influência sobre outras pessoas e acontecimentos externos ${ }^{(41)}$.

\section{PEPLAU, Hildegard E.}

A comunicação é um processo interpessoal terapêutico e significativo, funciona em cooperação com outros processos humanos, a fim de tornar alcançável a saúde dos indivíduos e sociedade. Introdutora do relacionamento terapêutico enfermeiro-paciente na Enfermagem, afirma que a Enfermagem precisa se familiarizar com as técnicas interpessoais de comunicação para validá-las na prática e decidir em que situações cada procedimento será mais útil $^{(41)}$.

\section{BALES, Robert F.}

Em seu estudo sobre o processo de interação, discerniu 12 categorias que representam funções de participação em um grupo de trabalho com a preocupação de auxiliar na resolução de problemas. As categorias distribuem-se em duas áreas de ocorrência: a área de tarefa e área socioemocional. A primeira é considerada neutra e engloba os comportamentos de perguntas e tentativas de respostas. A segunda pode ser positiva ou negativa, conforme as reações emocionais manifestadas pelos participantes.

A área de tarefa compreende as funções em nível de interação de conteúdo ou canalização de energia para a consecução dos objetivos comuns do 
grupo, enquanto a área socioemocional compreende as funções de manutenção do próprio grupo.

Os papéis assumidos com mais freqüência tendem a caracterizar a atuação do indivíduo no grupo. Os estudos do autor registraram a seguinte distribuição típica de comportamentos de interação dos membros no grupo: cerca de $12 \%$ de reações negativas, $25 \%$ de reações positivas, $7 \%$ de perguntas e $56 \%$ de respostas. Este resultado indica que a maior parte das interações nos grupos é realizada sob forma de respostas sem perguntas equivalentes, isto é, informações, opiniões e sugestões não pedidas. Menos da metade dos comportamentos interativos expressa reações positivas, negativas e perguntas ${ }^{(4)}$.

\section{MOSCOVICI, Fela}

Aborda, sobretudo, o desenvolvimento das competências interpessoais nas relações grupais e organizacionais. Ao explanar sobre competência interpessoal, parte dos questionamentos de como podemos trabalhar bem com os outros, de como podemos entender e fazer entender. Afirma que o contato inicial entre pessoas gera a chamada "primeira impressão" e comenta como as relações interpessoais se desenvolvem para a aquisição da competência interpessoal, gerencial e organizacional. Aborda a representação de áreas da personalidade, de acordo com a Janela de Johari ${ }^{(49,54)}$, para ilustrar as relações interpessoais e os processos de aprendizagem em grupo. Desenvolve o tema do feedback e sua importância nas relações interpessoais, funcionamento e 
desenvolvimento dos grupos, incluindo estilos pessoais de atuação, perspectivas de motivação e mudanças nos grupos ${ }^{(4)}$.

\section{Referenciais teóricos de comunicação, com uma citação, organizados por ordem alfabética}

\section{BARBERO, Jesus Martim}

Estuda a comunicação desde a cultura da vida cotidiana, a qual denomina de mediação cultural. Afirma que os estudos de comunicação encontram-se direcionados entre uma tendência fundamentalista e outra praticista. Em seus estudos latino-americanos, mostra as dificuldades encontradas na articulação do abordado na investigação com a temática estudada na docência, bem como a vagarosa consolidação em propostas curriculares da interação entre avanço teórico e renovação profissional. Indica que os estudos da comunicação apresentam dispersão, pelo fato de não estarem integrados a uma disciplina, mas, sim, por um conjunto de saberes e práticas pertencentes a diversas disciplinas e campos, desencadeando fragmentação do estudo e especialização das práticas, obedecendo a lógica do mercado de trabalho ${ }^{(36)}$.

\section{BENJAMIN, Alfred}

Aborda a comunicação em seu livro sobre a entrevista de ajuda iniciando com a afirmação de que "sem comunicação não haveria entrevista", pois a meta 
do entrevistador é facilitar a comunicação, embora com freqüência surjam obstáculos que a impedem, distorcem ou complicam. Entre os fatores que podem ajudar ou impedir a comunicação, estão as defesas e valores, assim, quanto menos defensivos nós nos tornamos, mais poderemos ajudar o entrevistado a deixar de lado suas defesas. Quanto mais tivermos consciência de nossa escala de valores, e quanto menos quisermos impô-la ao outro, mais estaremos aptos a ajudá-lo a ter conhecimento de seus próprios valores e mantê-los, adaptá-los ou rejeitá-los, como melhor lhe parecer.

Outros fatores que influenciam na comunicação, são o uso da autoridade, resultados de testes e julgamento como defesa. Reafirma nossa incapacidade de eliminar, totalmente, os obstáculos na comunicação, mas que devemos saber onde estamos criando-os e reduzi-los o máximo possível ${ }^{(55)}$.

\section{BERLO, David Kenneth}

Apresenta um modelo de comunicação originado de idéias, necessidades, intenções, informações e um objetivo a comunicar, afirmando que este tem de ser expresso em forma de mensagem. Assim, na comunicação humana, a mensagem existe em forma de tradução de idéias, objetivos e intenções num código ou num conjunto sistemático de símbolos. Afirma que, dificilmente, podemos deixar de nos comunicar, pois desde a infância aprendemos e praticamos as técnicas verbais e não-verbais de influenciar ou manipular o ambiente, qualquer situação humana compreende a produção e a recepção de uma mensagem por alguém. 
APRESENTACÃO DOS RESULTADOS E ANÁLISE DOS DADOS

Ressalta a importância de se ter um objetivo e defini-lo na comunicação e que as pessoas devem analisar seus objetivos ao se comunicarem e especificálos em termos das reações que pretendem obter.

Discute a comunicação como processo, afirmando que, desta forma, veremos os acontecimentos e as relações como dinâmicos, em evolução e mudança contínua. Quando chamamos algo de processo, queremos dizer também que não tem um começo ou um fim, é uma seqüência de eventos e os ingredientes do processo agem uns sobre os outros e cada um influencia todos os demais ${ }^{(56)}$.

\section{BLAKE, Robert Rogers \& MOUTON, Jane Hubbard Srygley}

Escreveram a respeito da liderança situacional e da estruturação de uma empresa dinâmica por meio do desenvolvimento organizacional, em que as pessoas são consideradas fontes de energia das empresas e as emoções podem produzir comprometimento e dedicação, mas também desinteresse e indiferença.

Sinalizam a importância do aprendizado da dinâmica comportamental para a diminuição das resistências e o avanço cultural; para isso criaram uma técnica de alteração comportamental denominada Grade Gerencial (Managerial Grid).

Para esses autores, todo gerente sempre está voltado para duas preocupações: a produção e as pessoas e a grade gerencial representa as duas ênfases dessa interação, caracterizando os estilos de liderança possíveis. Destacam a importância de cada gerente aprender a observar o seu estilo de 
liderança, por meio da grade, no sentido de fortalecer seu desempenho individual e avaliar a situação em que está vivendo(57).

\section{BLONDIS, Marion Nesbitt \& JACKSON, Barbara E.}

Abordam a comunicação não-verbal com pacientes, enfocando os movimentos corporais da equipe de Enfermagem e dos pacientes como emblemáticos, ilustradores, reguladores e como uma forma de demonstrar afetividade nas relações. Afirmam que os gestos freqüentemente acompanham a fala embora, raramente, tenhamos consciência disso no ambiente hospitalar. Do mesmo modo que a paralinguagem (tom, ritmo e velocidade da fala), a invasão do espaço pessoal (territorialidade), sem permissão, pode ser traumática para o paciente.

Consideram o uso do toque como o mais importante de todos os comportamentos não-verbais para a Enfermagem e incluem a clarificação das mensagens, o feedback e a comunicação terapêutica como influentes nas relações interpessoais que envolvem o cuidar ${ }^{(46)}$.

\section{BORDENAVE, Juan Diaz}

A comunicação é um processo natural, uma arte, uma tecnologia, um sistema e uma ciência social. Na comunicação, encontram-se dois mundos diferentes de experiências vividas. Os signos intermedeiam esses mundos, assim, a comunicação é possível quando as pessoas tiveram experiências prévias com os mesmos objetos ou com suas representações. Os signos são, 
portanto, convencionais, dependem do modo como as pessoas vão usá-los. O conjunto organizado de signos chama-se código. Cita os seguintes tipos de códigos: -comportamentais: são aqueles em que o comunicador usa seu próprio corpo, como gestos e expressões faciais; -artefatuais: compreendem os objetos e seus arranjos utilizados pelo homem, como roupas, bijouterias, móveis; -espaçotemporais: incluem aqueles que usam o tempo e o espaço para propósitos de comunicação, como ritmo de música ou localização das pessoas em um palco; mediatórios: aqueles que podem ser transmitidos por meios impessoais de comunicação, como a escrita, os gráficos ${ }^{(3,9)}$.

\section{CARVALHO, Emília Campos de}

Estudiosa de Enfermagem e comunicação, aborda a comunicação interpessoal e as teorias gerais da comunicação nos modelos de Enfermagem. Relata que o significado da comunicação varia a cada momento, dependendo da finalidade de seu uso e de seu conhecimento. Entende a comunicação como um processo e com valor intrínsico na interação enfermeiro-paciente, afirmando que a enfermeira deve ter esse conhecimento, para planejar, direcionar, implementar e avaliar a assistência de Enfermagem.

Pesquisou sobre o ensino de comunicação em Enfermagem no Brasil, concluindo que, até 1989, o mesmo não havia sido incorporado aos currículos, de maneira a provocar mudanças na prática profissional ${ }^{(44)}$. 


\section{CHANLAT, Jean-François}

Ao escrever sobre o indivíduo na organização, contesta a visão instrumental e adaptativa do indivíduo, que o levou ao individualismo em suas últimas conseqüências, e uma sociedade que reina "em curto prazo", que não se preocupou em transformar o trabalho, pois estava preocupada em acumular riqueza.

Afirma que "só uma concepção que procura apreender o ser humano na sua totalidade pode dele se aproximar sem, contudo, jamais o esgotar completamente ${ }^{(58) "}$.

\section{FREIRE, Paulo}

Vê o homem como um ser de relações que, desafiado pela natureza, a transforma com seu trabalho, e o resultado desta transformação constitui seu mundo. O sujeito pensante não pode pensar sozinho, não há um "penso", mas um "pensamos". Esta co-participação dos sujeitos no ato de pensar se dá na comunicação.

A comunicação implica reciprocidade que não pode ser rompida; desta forma, não existem sujeitos passivos, pois a comunicação implica diálogo. Na relação dialógica-comunicativa, os sujeitos interlocutores se expressam, por meio de um mesmo sistema de signos lingüísticos, que são indispensáveis, ou seja, a expressão verbal de um dos sujeitos deve ser percebida dentro de um quadro significativo comum ao outro sujeito ${ }^{(59)}$. 
Em "Pedagogia da Autonomia", faz uma reflexão sobre os saberes necessários a uma prática educativa crítica e ética, numa visão de mundo alicerçada em consciência, respeito, humildade, tolerância, alegria, esperança, competência, comprometimento e ideal, mas, acima de tudo, disponibilidade para o diálogo ${ }^{(60)}$.

\section{FRITZEN, Silvino José}

Apresenta exercícios práticos sobre a "Janela de Johari" idealizada por Luft e Ingham ${ }^{(49)}$, são vivências de dinâmica de grupo, objetivando a prática sobre o processo de dar e receber feeback nas relações interpessoais ${ }^{(54)}$.

\section{FURNHAM, Adrian}

Aborda a linguagem corporal no trabalho e suas funções não-verbais usadas para substituir, reforçar e, até contradizer uma mensagem verbal; ressalta que toda comunicação do corpo é uma expressão simbólica poderosa que pode controlar o envio de mensagens. Os sinais do corpo como o olhar, a expressão facial, os gestos, a orientação do corpo, a postura, o toque e outros, como roupas, odor e territorialidade influenciam na vida ocupacional.

O corpo também expressa claramente nossas emoções, independente de nossa vontade, por meio do rubor, transpiração, dilatação das pupilas, alterações no ritmo respiratório e assim por diante ${ }^{(61)}$. 


\section{HABERMAS, Jürgen}

Lançou o paradigma da comunicação, dentro do qual verdade é uma pretensão de validade. Cita que o parâmetro da discutibilidade (só pode ser científico o que for discutível) advém do paradigma da comunicação e para que ela possa ocorrer, precisa de outro ser comunicante. Assim, o autor afirma que a comunicabilidade é destruída se apenas um lado fala e ao outro, impõe-se o silêncio, ou se o outro lado apenas consente. Desse modo, o diálogo crítico e irrestrito torna-se o caminho da ciência.

Para este teórico, o lugar mais próprio da democracia está na liberdade irrestrita de questionar sob acentuada argumentação, investindo na inovação científica obtida pelo conhecimento, argumentado da melhor maneira possível.

A discussão crítica, conforme a proposta do paradigma comunicativo, contém duas dimensões mais fundamentais: o rigor formal científico, que é a arte de argumentar de modo crítico e criativo e, saber ouvir as razões alheias, procurando conferir aceitação àquelas melhor argumentadas.

Sob este aspecto, a linguagem denota a base da comunicação e a condição vital de saber expressar-se, um dos fundamentos mais notáveis da cidadania $^{(62,63)}$.

\section{HALL, Edward T.}

Refere-se sobre o tema do espaço social e pessoal e sua percepção pelo homem, alerta para o fato de que, assim como a linguagem tem diferenças culturais, isso acontece também com os outros veículos de interação. 
Desenvolveu a teoria sobre o uso humano do espaço interpessoal e exemplificou seus estudos com diferentes populações e distintas culturas. Criou o neologismo "proxêmica", como sendo o conjunto das observações e teorias referentes ao uso que o homem faz do espaço, como produto cultural específico, ou seja, como os indivíduos usam e interpretam o espaço dentro do processo de comunicação. Aborda aspectos da percepção do espaço, receptores a distância e imediatos, espaço visual, linguagem e dinamismo do espaço no ser humano, incluindo distância íntima, pessoal, social, pública e comparações da proxêmica nas diferentes culturas ${ }^{(64)}$.

\section{HAYS, Joyce Samhammer \& LARSON, Kenneth H.}

Estes autores descrevem e exemplificam, de modo mais completo, as técnicas de comunicação terapêutica mais úteis para à enfermeira: usar o silêncio, manifestar atenção, oferecer-se como elemento de ajuda, manter ambiente que ofereça segurança, estimular o paciente a continuar o assunto, colocar o evento em seqüência no tempo e no espaço, fazer observações, encorajar descrição de percepções, encorajar comparações, reformular idéias, devolver a pergunta feita, manter em foco o tema abordado, explorar o assunto, dar informações, clarificar idéias, mostrar a realidade, expressar dúvidas, validar a comunicação, verbalizar o implícito, encorajar a avaliação, tentar verbalizar os sentimentos subjacentes do paciente, sumarizar o que foi dito e encorajar o paciente a formular um plano de ação ${ }^{(41)}$. 


\section{HERSEY, Paul \& BLANCHARD, Kenneth H.}

Desenvolveram um modelo denominado Liderança Situacional que consiste na premissa de que não existe um único estilo de liderança apropriado para toda e qualquer situação, indicaram como estilos de liderança:determinar, persuadir, compartilhar e delegar ${ }^{(65)}$. O líder, liderados e a situação são as variáveis norteadoras do processo de liderança; entretanto, neste modelo a ênfase recai sobre o comportamento do líder em relação aos liderados frente a uma tarefa específica. Ressaltam que o ponto-chave para o uso da Liderança Situacional com sucesso consiste no reconhecimento do nível de maturidade do liderado em relação à determinada tarefa, ou seja, de acordo com o referencial da "Janela de Johari", desenvolvido por Luft e Ihgham ${ }^{(49)}$, indicam o feedback e a abertura como influentes, conforme os líderes estejam dispostos a compartilhar com os outros membros do contexto dados que lhes dizem respeito pessoalmente ${ }^{(66)}$.

\section{KING, Imogene M.}

A comunicação é um processo pelo qual a informação passa de uma pessoa a outra, tanto direta em encontros pessoais como indiretamente por meio de telefone, televisão ou por escrita. É o componente informativo das interações. Comunicação, portanto, nesse referencial, é o meio pelo qual a informação é dada, em situações específicas de Enfermagem, para identificar relações e ou problemas e para partilhar informações que ajudem os indivíduos na tomada de decisões e os leve a atingir os objetivos no ambiente ${ }^{(44,67)}$. 


\section{KNAPP, Mark L.}

Segundo este autor a comunicação não-verbal é classificada em: paralinguagem, como qualquer som produzido pelo aparelho fonador que não faça parte do sistema sonoro da língua usada; cinésica, como a linguagem do corpo, ou seja, movimentos desde gestos manuais, movimentos dos membros, meneios de cabeça, até expressões mais sutis, como as faciais; proxêmica, o uso que o homem faz do espaço como produto cultural específico, como a distância mantida entre os participantes de uma interação; características físicas, como sendo a própria forma e a aparência de um corpo, transmitindo informações sobre faixa etária, sexo, origem étnica e social, estado de saúde e, também, objetos usados pela pessoa como jóias, roupas, tipo de carro, fatores do meio ambiente: a disposição dos objetos no espaço e as características do próprio espaço, como cor, forma e tamanho e a tacêsica, tudo que envolve a comunicação tátil, estando relacionada com o espaço pessoal, cultura dos comunicadores e expectativas nos relacionamentos. Comenta sobre os efeitos que cada um destes sinais nãoverbais provoca nas relações e, também, sobre o desenvolvimento das habilidades para enviar e receber sinais não-verbais ${ }^{(11,68)}$.

\section{LEVIN, Morton L.}

Escreveu a respeito da comunicação que ocorre com o indivíduo em seu grupo, ou seja, realizou estudos de casos na comunidade, com abordagem compreensiva das doenças comunitárias, cirurgias epidemiológicas, sociais, psiquiátricas e de saúde pública ${ }^{(69)}$. 


\section{MACHADO, Maria Helena}

Estudiosa da assistência de Enfermagem centrada na pessoa, afirma que a motivação e o estímulo da profissão do enfermeiro são o paciente e as suas necessidades e, como pessoas, enfermeiros e pacientes interagem estabelecendo um processo entre eles. Ressalta que nem sempre o enfermeiro é capaz de satisfazer as necessidades do paciente e nem sempre é responsável por elas não terem sido atendidas, mas acredita que o enfermeiro é responsável pela tentativa de identificação das expectativas e atendimento ao paciente. Relata que, ao conhecerem e compreenderem os problemas dos pacientes, os enfermeiros serão capazes de aplicar conhecimentos, adaptar planos, fazer juízos clínicos e serem recompensados pelo fato de assistir o ser humano de uma forma total e indivisível, que não pode ser avaliada pela quantidade e, sim, pela qualidade ${ }^{(70)}$.

\section{MANZOLLI, Maria Cecília}

Estudiosa da formação do enfermeiro e de todas as facetas que envolvem os relacionamentos interpessoais em Enfermagem.

$\mathrm{Na}$ pesquisa sobre relacionamento em Enfermagem, afirma que em comunicação devemos criar estratégias e oportunidades para que o ambiente no qual um curso é ministrado, tenha o significado de um "encontro" professoraluno $^{(71)}$.

Comenta que o discente inicia o relacionamento com as pessoas com as quais irá trabalhar e, para tanto, é preciso que tenha conhecimentos e manifeste 
atitudes favoráveis referentes a esse relacionamento, que procure interagir efetivamente com indivíduos em idades diversas, com determinadas características e que vá percebendo valores que influenciam o comportamento humano.

Propõe o diálogo dos enfermeiros com o paciente, seus familiares, comunidades e equipe de saúde, visando ao relacionamento humano e, assim, poderão desenvolver métodos de trabalho que propiciem um melhor entendimento para si e aos outros.

Além de enfocar a importância da comunicação verbal e não-verbal, ressalta que o enfermeiro e o paciente podem transmitir mutuamente uma série de mensagens quando, por exemplo, o paciente expressa suas necessidades de proteção, segurança, reconhecimento e, por sua vez, o enfermeiro transmite presença e calor humano satisfazendo, assim, uma série de necessidades do paciente. Discute os aspectos psicológicos envolvidos na hospitalização, como mudanças no dia-a-dia dos pacientes, necessidades de adaptação à situação da doença, afastamento do ambiente familiar e social, que geram depressão, apatia, estresse, dependência e outros ${ }^{(72)}$.

\section{MENDES, Izabel Amélia Costa}

Estudiosa de comunicação em Enfermagem, apresenta uma proposta humanística para o exercício profissional em uma abordagem da comunicação verbal entre o grupo de Enfermagem e os pacientes. 
Entende a Enfermagem como um processo de interação humana e a comunicação como parte central desse processo, constituindo-se como um dos instrumentos mais significativos no agir do enfermeiro, reafirmando a necessidade do comprometimento dos enfermeiros e que eles saibam explicitar sua pessoa no relacionamento com os pacientes ${ }^{(73)}$.

\section{MORENO, Jacob Levy}

Criador da psicoterapia de grupo e do psicodrama, em seus estudos, mostra as origens do psicodrama nos ritos antigos e dos povos ditos "primitivos", afirmando que a psicoterapia foi primeiro grupal, depois se tornou individual, pois o homem foi, na sua origem, um ser coletivo. Conceitua papéis fisiológicos e psicodramáticos, mais especificamente, define papel como o modo de agir, que o indivíduo adota no momento em que reage a uma determinada situação, na qual outras pessoas ou objetos estejam envolvidos ${ }^{(74)}$.

\section{OREN, Dorothea E.}

A Enfermagem tem como especial preocupação a necessidade de ações de, oferecimento e controle de autocuidado em uma base contínua, para sustentar a vida e a saúde, recuperar-se de doença ou ferimento e compatibilizarse com seus efeitos. Desenvolve sua teoria geral de Enfermagem em três partes relacionadas que são: autocuidado, deficiências de autocuidado e sistemas de Enfermagem. Discute os conceitos fundamentais dos seres humanos: saúde, sociedade e Enfermagem, citando que o indivíduo difere de outras coisas vivas 
por sua capacidade de refletir a respeito de si mesmo e de seu ambiente, de simbolizar aquilo que vivencia e usar criações simbólicas (idéias, palavras) no pensamento, na comunicação e direcionamento de esforços para realizar e fazer coisas que tragam benefício a si mesmo ou a outros.

Desse modo o funcionamento humano integrado inclui aspectos físicos, psicológicos, interpessoais e sociais. Orem acredita que os indivíduos possuem potencial para a aprendizagem, e o desenvolvimento é a maneira pela qual um indivíduo satisfaz suas necessidades de autocuidado, que não é instintiva, pois é um comportamento aprendido ${ }^{(67)}$.

\section{SCHUTZ, William}

O foco da teoria deste estudioso, FIRO (Fundamental Interpersonal Relations Orientation), incide sobre as necessidades interpessoais, porque considera o comportamento interpessoal uma tentativa de satisfação de várias necessidades no relacionamento com os outros, que se desenvolve em quatro postulados.

No primeiro, o autor especifica as necessidades interpessoais, afirmando que todo o indivíduo tem três importantes necessidades interpessoais que são: inclusão, controle e afeição e este conjunto é necessário e suficiente para que se possa entender as relações interpessoais, ou seja, o modo como uma pessoa comporta-se perante os outros é determinado por essas três necessidades. Basicamente, inclusão refere-se ao grau de associação que o indivíduo precisa, 
controle é a necessidade da pessoa influir e exercer poder sobre os outros e afeição é o grau de amor necessitado pela pessoa.

O segundo postulado é o da continuidade de relações, que explica a origem do comportamento interpessoal do indivíduo, que são as relações paisfilho. A pessoa tende a padronizar seu comportamento em uma situação, de acordo com o comportamento recordado de uma situação semelhante na infância. A pessoa pode copiar seu próprio comportamento infantil ou o de seus pais.

O terceiro postulado é o da compatibilidade, pois a compatibilidade é importante no funcionamento eficiente de um grupo, sendo definida em termos de inclusão, controle e afeição expressos no comportamento dos membros do grupo. A compatibilidade aumenta o desejo de comunicar. Assim, este compartilhar aumenta a produtividade.

O quarto postulado relaciona-se com a formação do grupo, quando o grupo se desenvolve, passa por uma seqüência de comportamentos de inclusão, controle e afeição. Se o grupo prevê que a associação terminará, inverterá, então, o padrão antes de se dissolver, voltando a passar por uma fase de controle e terminando com a inclusão. Assim, a história do comportamento dominante de um grupo obedece ao padrão de inclusão-controle-afeiçãocontrole-inclusão(2). 


\section{SKINNER, Burrhus Frederic}

O ambiente exerce papel decisivo na formação do homem; expoente da análise funcional do comportamento humano, afirma que cada parte do comportamento é função de alguma condição passível de ser descrita em termos físicos, como é o comportamento em si. Em termos instrucionais, poderíamos afirmar que o sucesso do ensino dependeria de uma cuidadosa análise dos efeitos dos "reforçadores", do planejamento e execução da seqüência de tarefas de aprendizagem em que uma resposta é seguida de um estímulo reforçador ${ }^{(75)}$.

Para Skinner ${ }^{(76)}$ : "o comportamento humano é demasiado complexo para que se deixe a tarefa de modelá-lo à experiência casual ou, inclusive, a uma experiência organizada no restrito ambiente das aulas".

\section{SOMMER, Robert}

Estudou os sinais não-verbais, sobre o espaço pessoal e os aspectos ambientais em sala de aula, nos quais nos mostra que os espaços planejados para o ensino são aceitos sem discussão por aqueles que planejam as instalações educacionais, bem como os que as usam. Acrescentou que restrições espaciais são acompanhadas por regras administrativas impostas, cuja formação não inclui a participação do aluno. Chegou a afirmar que os professores sentem dificuldades com seus alunos em sala de aula, porque estão insensíveis ao ambiente, aceitando-o, e repassando esta aceitação fatalista a seus alunos ${ }^{(77)}$. 


\section{SUNDEEN, Sandra J.}

O relacionamento cliente-enfermeiro é o elemento básico da experiência bem sucedida do cuidar, e a enfermeira deve usar seu conhecimento do processo de relação e ou interação para ajudar o cliente em suas metas viáveis de saúde. Isto requer autoconsciência e compreensão dos próprios sistemas de valores como, por exemplo, confiança, empatia, bondade, esperança, autonomia e cumplicidade. Conceitua estes valores e propõe intervenção da enfermeira nas dimensões afetiva, cognitiva, comportamental, de afiliação, temporal e contextual. Ressalta que o cuidado de Enfermagem é baseado no conhecimento das preferências e características do paciente e que, ao desempenhar seu papel de cuidar protegendo o paciente, a enfermeira ressalta sua autonomial ${ }^{(78)}$.

\section{WATSON, Jean}

O cuidado é a essência da Enfermagem e supõe sensibilidade entre a enfermeira e a pessoa, argumenta que o cuidado pode ajudar a pessoa a adquirir controle, conhecimentos e promover mudanças de saúde. Sua teoria tem alta consideração pela autonomia e liberdade de escolha, com ênfase para o autoconhecimento e o autocontrole.

A estrutura para a ciência do cuidado é constituída sobre dez fatores, que são: a formação de um sistema de valores humanistas, instilação de fé e esperança, cultivo da sensibilidade, desenvolvimento da relação de ajuda, a promoção e a aceitação da expressão de sentimentos, o uso do método científico para a tomada de decisão, a promoção do ensino-aprendizagem, promoção de 
um ambiente de apoio, assistência às necessidades humanas e permissão de forças existencial-fenomenológicas ${ }^{(67,79)}$.

\section{WATZLAWICK, Paul}

Para o autor, todo comportamento em uma situação interacional tem valor de mensagem, isto é, a comunicação, por mais que o indivíduo se esforce, é-lhe impossível não comunicar.

Relaciona qualquer comunicação como um compromisso que define a relação, ou seja, uma comunicação não só transmite informação, mas também impõe um comportamento. Este processo, com numerosos modos de comportamento, é capaz de trocas variadas de grande complexidade que vão desde o congruente ao incongruente e paradoxal. Nas situações interpessoais, estes efeitos pragmáticos são abordados em toda a obra do autor ${ }^{(21)}$.

\section{Os referenciais nos modelos teóricos de Enfermagem}

Para Carvalho ${ }^{(44)}$, os referenciais teóricos de Enfermagem podem ser classificados nos modelos interacionistas, desenvolvimentistas e sistêmicos.

A autora entende como modelos Interacionistas, os que valorizam os atos e as relações sociais entre pessoas, enfocando a identificação dos problemas atuais e potenciais nas relações interpessoais e buscam estratégias de intervenção para promover um nível ótimo de socialização. Revelam a capacidade humana para comunicar sentimentos significativos, apontando para a 
capacidade das pessoas interagirem, mediante símbolos, como palavras, imagens e sinais. Os modelos desenvolvimentistas têm como característica principal, a troca, estando, esta, relacionada com diferentes estados ou fases de desenvolvimento e maturação. Na natureza das trocas, existe a idéia de crescimento e maturação, tanto para o processo de ganho quanto para o de perda, como a morte. Desenvolvimento é entendido como sendo uma função do processo de interação entre o organismo e o ambiente; os modelos sistêmicos - (Teoria Geral de Sistemas) consideram o fenômeno como se existisse organização, interação, interdependência e integração das partes e elementos, constitui elemento característico, também, a retroalimentação, seu foco é o exame das partes do sistema e suas relações num dado tempo. As trocas características dos modelos descritos têm importância secundária nos sistêmicos. Aqui, a ação do enfermeiro busca o equilíbrio existente com e entre eles.

De acordo com a classificação apresentada por Carvalho ${ }^{(44)}$, em nossa pesquisa foram citados os seguintes referenciais teóricos:

- no modelo interacionista: Travelbee, Joyce

- no modelo desenvolvimentista: Peplau, Hildegard E. e Orem, Dorothea E.

- no modelo sistêmico: King, Imogene M.

Para Sandoval ${ }^{(36)}$, a comunicação faz parte das construções teóricas da Enfermagem, mas são poucos os estudos na área de comunicação em Enfermagem que buscam discutir os fundamentos epistemológicos da natureza 
dos fenômenos comunicacionais presentes na prática, bem como a formulação de um marco conceitual que permita compreender, explicar e promover os grandes sistemas sociais que mediatizam as práticas do discurso e a produção de conhecimentos nessa área.

Neste estudo, foram apontados 11 autores, citados por dois ou mais sujeitos e 29 autores, referidos por um sujeito entrevistado. Obtivemos, portanto, a indicação de quarenta referenciais teóricos, situados, basicamente, nos referenciais de comunicação interpessoal, que são utilizados como base para o estudo da comunicação em Enfermagem. 


\subsection{A EXPRESSÃO DA COMPETÊNCIA COMUNICATIVA}
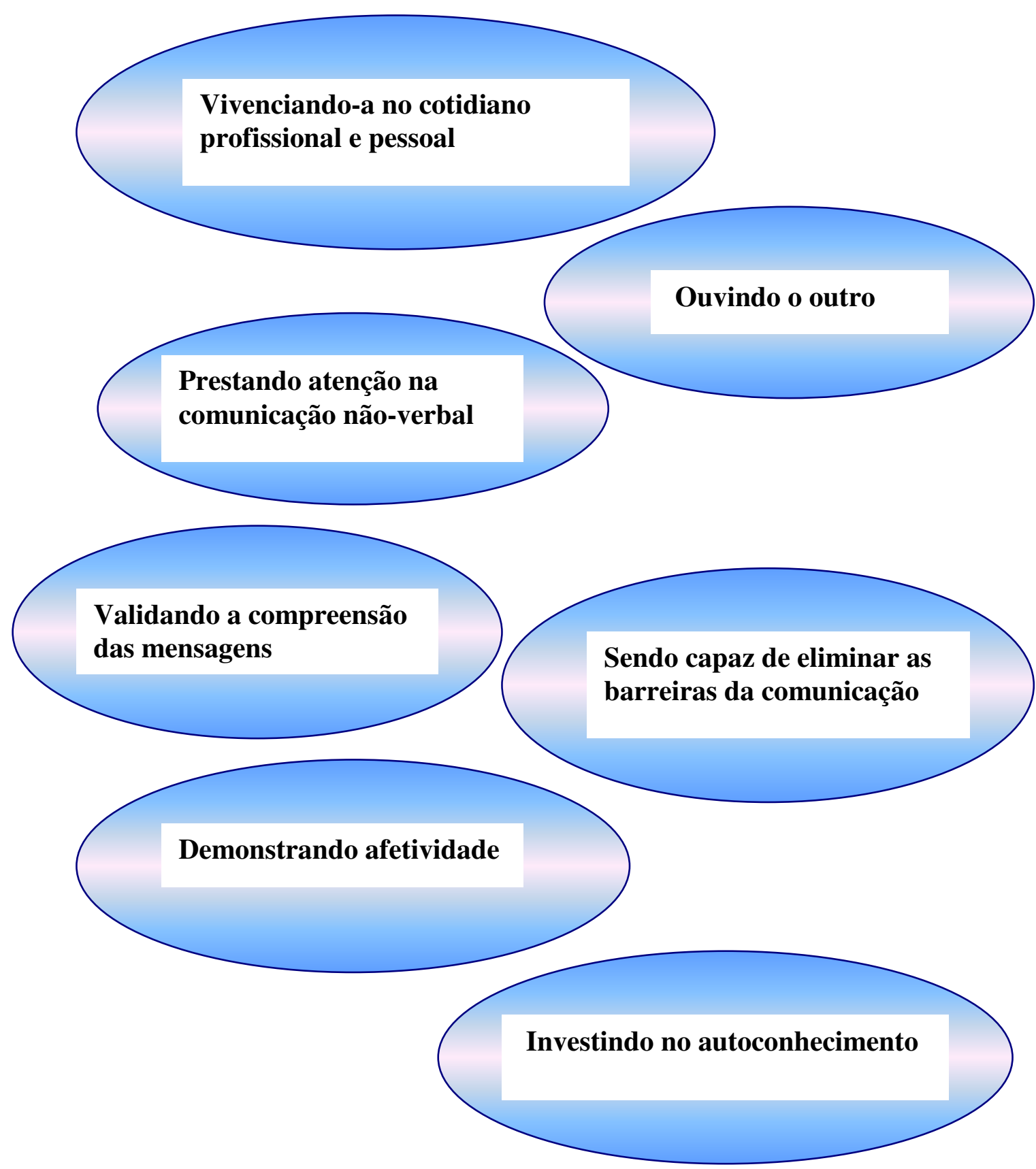

Esquema 3. A expressão da competência comunicativa 
$1^{\text {a }}$ categoria: Vivenciando-a no cotidiano profissional e pessoal

Os entrevistados relatam que expressam sua competência comunicativa vivenciando-a no cotidiano profissional e pessoal, aplicando os conhecimentos adquiridos no modo de ensinar, conduzindo o aluno para um aprendizado que considera o outro e suas necessidades nas mais diversas formas de cuidar. $\mathrm{Na}$ área da pesquisa, a expressão da competência comunicativa foi relatada como o cuidado com os sujeitos das pesquisas e a representação ética para com os indivíduos participantes, o que vale também para as publicações, nas quais a expressão da competência valoriza a participação eficaz de todos os elementos que fazem parte de um estudo ou projeto.

No que tange à participação em eventos, a habilidade comunicativa facilita a interação com o outro e abre caminhos ao crescimento profissional. Os entrevistados destacam que vivenciar comunicação é entender que existem facilidades e dificuldades nessa expressão. Uma pessoa competente em comunicação percebe o momento de expor suas idéias e o momento de apresentá-las e ficar em silêncio.

Outro aspecto salientado pelos pesquisados é que, mesmo um comunicador competente tem suas limitações nesta expressão. Além disso, foi ressaltado o entendimento de que a vida pessoal é uma continuidade da profissional e vice-versa, isto é, conhecimentos adquiridos em cada uma dessas facetas podem ser aplicados na outra, não é possível dividi-los com base em um ponto limitante. 
eventos, compartilhando idéias etc. Na vida pessoal, é uma continuidade, eu acabo aplicando os conhecimentos que adquiro na vida profissional, não consigo dividir." (E 1)

"Expresso minha competência profissionalmente e pessoalmente, é impossível você aprender comunicação estritamente na área profissional, quer dizer, você aprende e apreende." (E 6)

"Você tem a hora certa de se comunicar com a equipe, tem que ter o cuidado do que falar e como falar para existir realmente uma interação efetiva." (E 8)

"Exercito a competência em comunicação no dia-a-dia, no trabalho, estimulando os alunos para que detectem pontos positivos ou dificuldades em relação à comunicação. Explicito meus sucessos e meus "foras" na comunicação." (E 12)

Conforme cita Bordenave ${ }^{(3)}$, é por meio da comunicação que as pessoas se relacionam, compartilham experiências, idéias e sentimentos, ao se relacionarem, influenciam-se.

Bezerra $^{(6)}$ complementa, afirmando que a comunicação é algo que conhecemos, sentimos e vivenciamos no cotidiano.

Neste sentido, as relações professor-aluno fundamentam-se em fatores determinantes, que são as características pessoais, sociais e escolares de cada participante do processo comunicativo.

Nas características pessoais, percebemos que professor e aluno revelam suas qualidades inatas, facilitando ou dificultando a relação, e, nas características sociais, professor e aluno interagem e assemelham-se, de acordo com objetivos comuns, cultura, valores e crenças, embora o professor seja o maior responsável por determinar o tipo de interação que haverá entre eles ${ }^{(6)}$. 
No sistema escolar, professor e aluno assumem papéis de reciprocidade que contribuem para a interação e compreendemos que esta relação não se limita ao conteúdo comportamental, mas, a uma extensão do controle que o comportamento de um participante exerce sobre o outro ${ }^{(6)}$.

A representação de uma vivência ética foi citada pelos sujeitos, pois, segundo Freire ${ }^{(60)}$, a abordagem ética é uma proposta educacional que proporciona a libertação do outro, visando a autovalorização e autoderminação, para que o indivíduo torne-se capaz de tomar decisões, também, éticas e humanas.

No estudo sobre a ética no processo de ensino e aprendizagem em Enfermagem obstétrica, os resultados mostraram que as abordagens éticas nesse processo precisam ser discutidas com mais clareza, profundidade no conhecimento e adequação às realidades vivenciadas ${ }^{(80)}$, o que corrobora 0 discurso dos sujeitos de nossa pesquisa quando afirmam que as competências devem ser demonstradas no cotidiano.

$2^{a}$ categoria: Ouvindo o outro

Outra forma de expressão da competência comunicativa citada por mais de $50,0 \%$ dos participantes na pesquisa foi que devemos "ouvir o outro", observálo e prestar atenção, mesmo que estejamos em um "dia difícil” ou com muitas ocupações. É importante que o outro se perceba ouvido, isto é, saiba que ele tem espaço para expressão de suas idéias ou solicitações. Ficou evidente que esta escuta deve acontecer de modo ativo, interessado e com atitude compreensiva. 
A capacidade de ouvir adquirida com a competência não significa que as pessoas possam falar o que quiserem, no momento que o desejarem. 0 comunicador competente deve ter organização de tempo e espaço para poder fornecer tempo e espaço necessários à expressão do outro.

"Parar para olhar o outro, prestar atenção, saber ouvir, por exemplo: eu recebo aqui um coordenador, ele vai falando, falando, e eu, num dia difícil..., então eu falo: veja, eu não vou poder te dar atenção agora, porque estou muito ocupada, agora eu não posso. Eles querem falar e dizem: "preciso falar", "preciso falar". É difícil isso. Eu digo: "agora não posso", para tentar fazer as coisas direito. E trabalhoso, exige treino e atenção contínua." (E 3)

"Eu utilizo muito a observação e o ouvir o outro, que é uma coisa muito importante no processo de comunicação." (E 4)

"É importante que a pessoa fale e seja ouvida atentamente e todo o modelo de procedimento que eu proponho, é baseado na escuta e na atitude compreensiva do enfermeiro." (E 5)

"Expresso competência comunicativa, fundamentalmente, ouvindo o outro." (E 7)

"Desde que eu comecei a trabalhar, eu sempre tentei olhar para a equipe de Enfermagem e ouvi-los, porque eu acho que esta é a questão, você tem que ouvir." (E 8)

"Creio que a competência comunicativa se apresenta quando sou capaz de ouvir..." (E 10)

"Tento ouvir de modo ativo." (E 13)

Ouvir é uma atitude não-verbal de comunicação e, de acordo com o referencial teórico ${ }^{(38)}$ que embasa este estudo, é parte da comunicação interpessoal e implica uma forma de apresentação do eu a outros, em que a meta desejada é o maior entendimento dos envolvidos no processo. 
Sob este aspecto, Silva(11) afirma que, para ouvir, precisamos ficar em silêncio, demonstrar interesse e, sobretudo, aprender a controlar nossos sentimentos e preconceitos.

Nas palavras de Freire ${ }^{(60)}$ :

"ensinar exige saber escutar, somente quem escuta paciente e criticamente o outro, fala com ele, e jamais fala impositivamente.

O educador que escuta, aprende a difícil lição de transformar seu discurso ao aluno, em uma fala com ele".

\section{3ํㅗㄹ categoria: Prestando atenção na comunicação não-verbal}

Uma das formas de expressar a competência comunicativa é ir, além das palavras, é estar atento a todos os sentidos, observando o olhar, os gestos, as posturas corporais, objetos usados pela pessoa e atitudes, como a forma de sentar e movimentar-se. Dar atenção às informações transmitidas além do que ouvimos, como disse um entrevistado, "se o corpo fala, nós precisamos aprender a ouvi-lo".

"Eu tive um professor que dizia que se o profissional de saúde soubesse conversar com o corpo e com a pessoa do paciente, ele conseguia a informação que ele quisesse. Precisamos prestar atenção a uma informação, mesmo que ela não seja ouvida, pois o "corpo fala", fala mesmo, então, nós precisamos aprender a ouvi-lo." (E 9)

"Expresso minha competência quando sou capaz de ouvir, ver, tocar, cheirar, sentir o gosto, perceber, interpretar e responder adequadamente a cada um destes estímulos, não pressupondo um padrão, mas, um grau de satisfação nas respostas." (E 10) 
Comunicação não-verbal é uma habilidade que pode ser aprendida e ensinada. Na Enfermagem, o conhecimento desta habilidade está relacionado com o sucesso e eficácia nos procedimentos, além disso, o conhecimento da comunicação não-verbal pode ser usado para criar um ambiente de qualidade educacional e terapêutica ${ }^{(46)}$.

Prestar atenção às atitudes corporais é admitir o corpo, como forma de expressão, que tem efeitos sobre nós e os outros. São gestos, expressões faciais, tom de voz, postura, distância interpessoal, etc. Alguns desses efeitos, nós temos a intenção ou desejamos demonstrar, mas, outros igualmente contidos em nossas expressões, nós não queremos, não percebemos ou nem aceitamos expor $^{(19,49)}$

Uma das premissas teóricas básicas do estudo de Silva ${ }^{(38)}$, é que 0 enfermeiro não pode negar ou ignorar a dimensão do não-verbal no desempenho de suas atividades, confirmada nos discursos deste estudo, quando os sujeitos relatam que expressam competência comunicativa, prestando atenção à comunicação não-verbal do outro.

\section{$4^{a}$ categoria: Validando a compreensão das mensagens}

Ser capaz de perceber se a mensagem foi compreendida pelo outro e validá-la sempre é uma forma de expressar competência comunicativa. Os entrevistados mencionam que a validação de uma informação é singularmente 
importante para o cuidar em saúde, porque as pessoas podem se encontrar frágeis ou debilitadas por um diagnóstico. Esta fragilidade, do momento, pode fazer com que os indivíduos entendam as mensagens de forma distorcida e isto se tornar uma dificuldade na compreensão adequada de determinada informação.

"Eu me preocupo sempre em saber se as pessoas entenderam o que falei, eu costumo validar a comunicação, eu reforço muito a validação da informação recebida, principalmente, quando se trata do Consentimento Livre e Esclarecido. Me preocupo para que este seja realmente, esclarecido, assinado e só depois de validado."(E 2)

"Preocupo-me com a validação da compreensão da mensagem, tanto da pessoa com quem eu interajo, como com a compreensão desta pessoa sobre a minha comunicação." (E 2)

Para Stefanelli ${ }^{(41)}$, a validação da comunicação deve acompanhar todo o processo do relacionamento terapêutico e é necessária porque as mensagens emitidas precisam ter a mesma significação às pessoas envolvidas. A autora afirma que, quando não clarificamos e validamos as mensagens dos pacientes, estamos sujeitos a agir com base em nossos próprios valores, crenças ou interpretações errôneas, e sugere técnicas de comunicação terapêutica para a verificação da compreensão das mensagens, como: repetir a mensagem do paciente, pedir ao paciente para repetir o que foi dito e sumarizar o conteúdo da informação.

Bordenave $^{(3)}$ denomina esta fase da comunicação de "interpretação", pois consiste em compreender, não apenas o que cada palavra significa, mas o que a mensagem inteira pretende dizer. Ressalta que a interpretação exige que se 
coloque a mensagem em um contexto, que se compare com outros elementos envolvidos e com o conhecimento que se tem das intenções do interlocutor.

\section{5ª categoria: Sendo capaz de eliminar as barreiras da comunicação}

Uma pessoa que tem competência em comunicação, é capaz de perceber o que pode estar interferindo ou impedindo a comunicação. As relações ocorrem entre pessoas e, portanto, são passíveis de facilidades e dificuldades que podem alterar, bloquear e até inviabilizar a comunicação. Poderíamos citar o exemplo de um paciente com intubação endotraqueal com problemas de audição. Ele não consegue escutar o que está sendo comunicado, e o profissional responsável pelo seu cuidado precisa ter a capacidade de eliminar esta barreira comunicativa.

\begin{abstract}
"Eu penso que trabalhar com a disciplina de comunicação contribuiu para perceber, no contexto, as questões, os elementos que estão impedindo, interferindo. Isso existe, você trabalha com pessoas e há situações incontroláveis, há fatores influenciando, mas você tem a consciência do que está acontecendo, do que está envolvido, mesmo quando a comunicação se torna impossível, inviável, bloqueada, alterada, etc." (E 6)
\end{abstract}

"A gente não consegue o tempo todo, porque o processo de comunicação tem uma série de obstáculos, de dificuldades..."

(E 8)

O reconhecimento dos fatores que interferem na comunicação deve ser uma prioridade para quem estuda ou ensina comunicação na Enfermagem, com isso, podemos treinar e estimular este aprendizado.

Silva ${ }^{(11)}$ apresenta os fatores que podem se tornar barreiras comunicativas, como a motivação, emoções, expectativas, estereótipos, 
experiências anteriores, reconhecimento de sinais, conhecimento prévio do emissor, tempo do estímulo apresentado, limitações físicas (tato, visão, audição, etc.) e ruídos.

Além disso, podemos considerar a postura corporal, o contato dos olhos, a disposição dos móveis, o modo de vestir, a expressão facial, os maneirismos, o volume, ritmo, tom de voz e a distância interpessoal, como passíveis de se tornarem barreiras comunicativas.

\section{6ํㅡㄹ categoria: Demonstrando afetividade}

Expressar competência comunicativa é ser capaz de demonstrar afetividade, dar atenção e estar com o outro. Isso implica ser sensível, empático, flexível, isto é, dar abertura e respeitar o outro. Esta demonstração de afeto é, especialmente, importante na relação com o aluno, o que o deixa seguro e interessado em avançar.

"Eu acho muito importante demonstrar afeição, principalmente, com aluno, é sempre bom você demonstrar sentimento. A questão afetiva é muito importante." (E 4)

"Dar atenção, afeto, estar junto, é uma forma de expressar competência comunicativa." (E 9)

"Procuro demonstrar que estou atenta, respeito o tempo do outro, demonstro disponibilidade na interação." (E 13)

"Sou, constantemente, desafiada a ser empática, flexível, aberta, sensível e amorosa que são atitudes necessárias a serem desenvolvidas para favorecer a comunicação competente." 
Manifestações afetivas são expressões faciais que mostram estados emocionais que podem ou não ser intencionais, estas podem enfatizar, contradizer ou até não serem relacionadas com as palavras ditas ${ }^{(38,46)}$.

No estudo sobre o professor real e o ideal, na visão de graduandos de Enfermagem, as autoras mostram que os alunos apontam atitudes negativas e indesejáveis dos "piores" professores, considerados por eles. Nas conclusões, afirmam que os aspectos afetivos da relação professor-aluno são mediadores para que, pelo domínio do conteúdo e dos aspectos didático-pedagógicos dos docentes, o processo de ensino-aprendizagem concretize-se com sucesso ${ }^{(81)}$.

No que se refere à expressão da competência no ensinar, Gadotti ${ }^{(15)}$ afirma $^{2}$ que o ensino é uma relação pessoal e humana, é um encontro cujo sentido varia com a idade e personalidade de seus integrantes, e todo encontro com alguém é sempre uma possibilidade de amar que se desdobra em cada um. Coexistir é, sempre de uma forma ou outra, dialogar, evocar, invocar e ser do outro, portanto, amor e amizade têm um valor educativo muito grande.

7aㅡ categoria: Investindo no autoconhecimento

Investir no autoconhecimento é fundamental para a aproximação com o outro, é trabalhar com nossos próprios sentimentos e emoções para conseguir uma interação efetiva.

O autoconhecimento faz com que as pessoas mudem de atitudes, ficando mais atentas a si e ao outro e, conseqüentemente, desenvolvam-se como seres humanos. 
"O autoconhecimento é fundamental porque você não consegue ver o outro, vem aquele turbilhão de emoções, sensações e pensamentos a respeito das coisas e se você não tem um olhar para si, é difícil você ter uma comunicação efetiva e se permitir até olhar para o outro." (E 3)

"Expresso-me aplicando os princípios da linha de comunicação que eu sigo no meu trabalho; sou muito emotiva, impulsiva, mas tenho um bom controle sobre minhas ações." (E 5)

"Eu mudei algumas coisas, isso aconteceu comigo também, você vai ficando mais atenta à comunicação, às pessoas, procurando entender melhor e, é lógico, que você se desenvolve pessoalmente." (E 6)

O reconhecimento do outro e o respeito a ele devem coexistir com o autoconhecimento e a exigência de respeito da parte dele. É uma relação efetivamente dialética, ou seja, ao me voltar para mim mesmo, encontro o outro, e para me voltar para ele, é necessário que eu me volte sobre mim mesmo. É, portanto, a exigência essencial de um respeito mútuo na relação entre os indivíduos ${ }^{(50)}$.

O homem é um ser em desenvolvimento contínuo, atualiza-se a cada momento e renova o ambiente em que vive, relacionando-se com ele de forma dialógica e dialética. Ao interagir com os estímulos que recebe de seu meio, este estrutura e aprofunda o conhecimento sobre si mesmo e no contexto em que atua, envolvendo-se em um processo de valoração e avaliação, no qual as ações adquirem significado, a partir disso faz escolhas, de acordo com sua visão de mundo e as experiências vividas ${ }^{(82)}$.

O autoconhecimento é importante para a enfermeira relacionar-se, efetivamente, com o paciente e esta habilidade deve ser desenvolvida nos alunos, isto é, devem ser oferecidas oportunidades para que o aluno perceba-se como 
pessoa nas interações, com seus sentimentos, medos, ansiedade, raiva, inadequação, insatisfação etc. para que possa relacionar-se de forma autêntica e aberta $^{(78)}$.

Sob este aspecto, na pesquisa de Sadala ${ }^{(83)}$, encontramos o significado que os alunos atribuem à experiência de estar e ou cuidar do paciente em isolamento: "avaliando como vêem a si na relação com o paciente, avaliando-se na sua relação com o isolamento, avaliando o significado dessa experiência para as suas atividades futuras". Desse modo, nessa pesquisa fica evidente que a experiência, a reflexão e a descoberta conduzem a novas possibilidades de agir como profissional e pessoa. 


\subsection{COMO SE DESENVOLVE A COMPETÊNCIA COMUNICATIVA}

Estímulo recebido desde a graduação

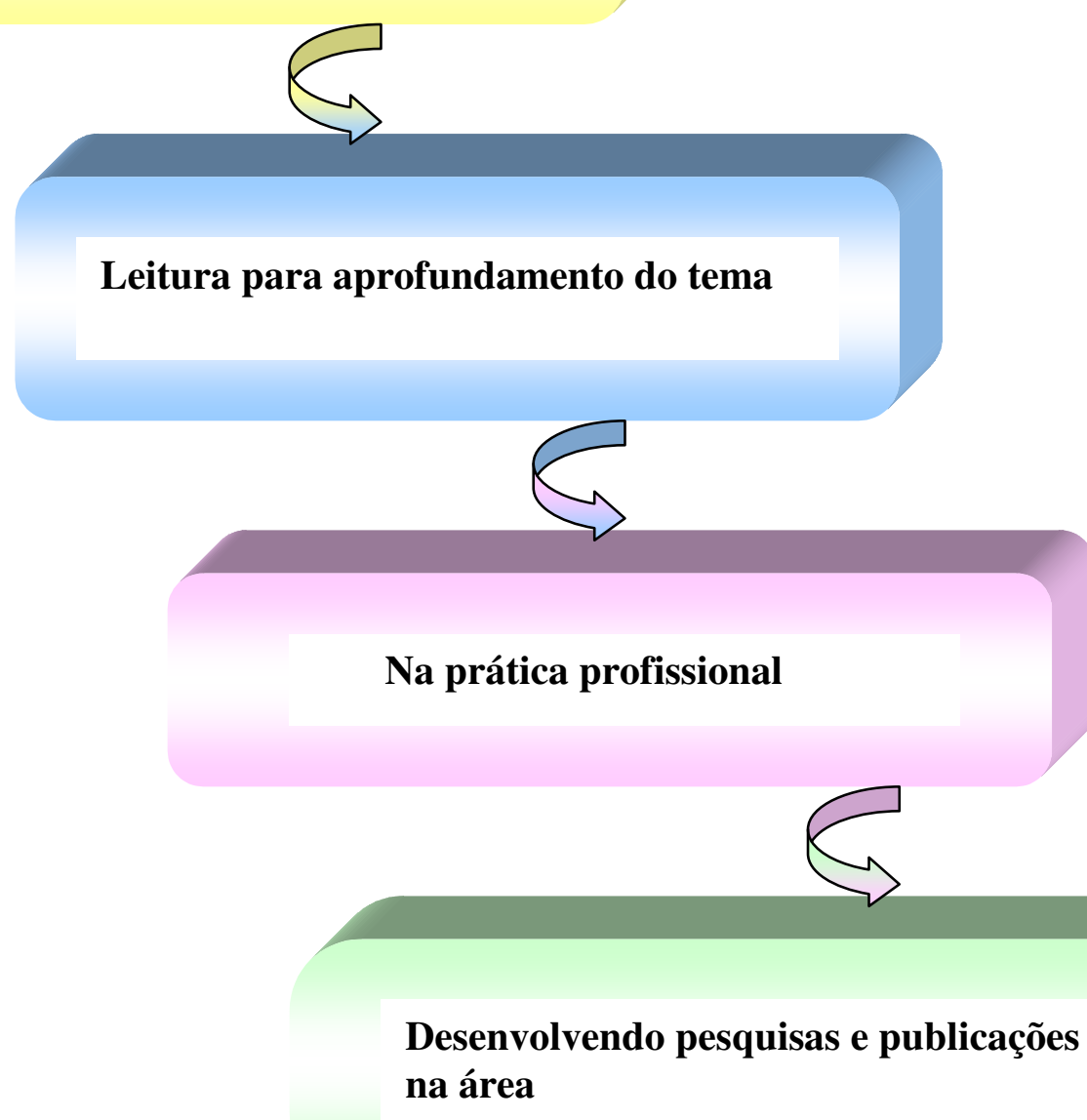

na área 


\section{1르 categoria: Estímulo recebido desde a graduação}

Pelas entrevistas, é possível percebermos um destaque à importância do estímulo para aprender comunicação desde a graduação em Enfermagem. As afirmações fizeram com que percebêssemos que as aulas sobre princípios básicos em comunicação, a prática do relacionamento interpessoal, as entrevistas com os pacientes, as leituras sobre o tema e as atividades práticas das disciplinas proporcionam a base para o desenvolvimento da competência comunicativa.

"Eu acho que desde a graduação, a gente tem este conteúdo do processo de comunicação e através do mestrado e doutorado que eu fiz na linha da comunicação." (E 4)

"Num dos meus estágios do curso de graduação, durante os meus plantões noturnos passava algumas horas conversando com meus pacientes e eles chegavam a expressar: "já conversamos, agora vou dormir" e dois dias após, quando eu voltava a me encontrar com eles a primeira coisa que me falavam era "ontem, eu não consegui dormir, senti falta do nosso papo". Aí, eu comecei a perceber o quão poderoso é o remédio comunicação." (E 7)

"Na graduação, assistindo a aulas sobre comunicação, entrevista, relação de ajuda, lendo textos indicados e realizando atividades de campo nas disciplinas, observando 0 comportamento de meus professores na relação conosco e com os pacientes. A base foi lá." (E 13)

Em seu estudo sobre o significado da comunicação para profissionais de Enfermagem na interação com o recém-nascido e a família, Pinheiro ${ }^{(84)}$, reafirma a importância da motivação na comunicação com os alunos, pacientes e familiares. Relata que, pela força da motivação, as pessoas iniciam as interações, estabelecem metas, além disso, percebem e interpretam reações nas mensagens verbais e não-verbais. Enfatiza a motivação como uma precondição para a 
comunicação eficaz, na qual as habilidades pessoais podem ser usadas como estratégias de aproximação.

Para que o processo educativo seja eficiente, o professor precisa lançar mão de estratégias, como meio de alcançar a aprendizagem desejada, estas devem ser variadas, favorecendo a individualidade dos alunos para aprender e, assim, o professor desenvolve o papel de facilitador da aprendizagem ${ }^{(27)}$.

Neste enfoque humanista, o processo formativo do enfermeiro é centrado na pessoa do aluno, tendo como participantes o paciente e a equipe. $O$ aprendizado da relação compreensiva e respeitosa, com a pessoa que precisa de ajuda, inicia-se, portanto, no processo educativo do enfermeiro ${ }^{(10)}$.

\section{$2^{\text {a }}$ categoria: Leitura para aprofundamento do tema}

No que se refere ao desenvolvimento da competência comunicativa, os entrevistados, em sua maioria, procuram por leituras e aprofundamento do tema, também, por meio de pesquisas e descoberta de modelos teóricos e profissionais, isto é, pessoas que se evidenciaram na área de comunicação, mais especificamente, em comunicação interpessoal.

Os sujeitos ressaltam a importância de se acreditar que comunicação é aprendida e este aprendizado pode ser desenvolvido. Citam a necessidade da assimilação de referências teóricas e a condição de estar aberto a novas propostas metodológicas como essenciais ao aperfeiçoamento e desenvolvimento desta capacidade. 
"Tenho feito leituras, procurando me aprofundar em pesquisas, me considero ainda em desenvolvimento da minha competência." (E 1)

"Comecei a ler muito, fui atrás, descobri os modelos teóricos, fui ler quem influenciou quem e fui formando um corpo de conhecimentos. Tudo o que eu achava de comunicação, eu lia..." (E 2)

"Eu li muito na linha de comunicação, eu acho que o desenvolvimento desta competência vem desde aí." (E 4)

"Eu sentia que não tinha clareza sobre que tipo de comunicação era essa... nosso instrumento de trabalho, as bases, as técnicas que poderiam melhorá-la. Aí, eu comecei a estudar esse assunto, eu estava nessa busca, continuei buscando com leituras, era tudo que eu tinha no momento." (E 5)

"Dediquei-me ao estudo da comunicação. Tenho investido nisso, me considero ainda iniciante e, por isso mesmo, a cada dia procuro me aprofundar nesses estudos, até porque, desenvolver a competência comunicativa é desenvolver a capacidade de cada dia ser mais gente e por isso, esse é um desafio interminável." (E 7)

"Com leitura, eu acho que tem muita literatura sobre este tema, eu acho que na Enfermagem é um tema muito rico." (E 8)

"Através de modelos, exemplos, estudo próprio e de acreditar que isso pode ser desenvolvido. Comunicação se aprende, comunicar se aprende." (E 9)

"A busca se faz pela assimilação de referências teóricas, estar aberto a novas propostas e metodologias são essenciais para 0 aperfeiçoamento" (E 10)

"Li, estudei, refleti, ora sozinha, ora com minha orientadora, ora com docentes de disciplinas correlatas." (E 13)

Demo $^{(24)}$ afirma que o conhecimento é uma ferramenta importante da competência, mas não assegura uma ação competente. É a capacidade e a 
coragem para inovar, associada a outras habilidades cognitivas e comportamentais que configuram o perfil do indivíduo competente.

Nas palavras de Freire ${ }^{(60)}$ :

"Nenhuma autoridade docente se exerce ausente da competência. O professor que não leve a sério sua formação, que não estude, que não se esforce para estar à altura de sua tarefa não tem força moral para coordenar as atividades de sua classe. O que quero dizer é que a incompetência profissional desqualifica a autoridade do professor".

Percebemos que a busca e o aperfeiçoamento na área de comunicação são marcas dos especialistas na área, confirmando que competência em comunicação, assim como em outras áreas pode ser aprendida e adquirida. Especialistas em comunicação são, portanto, pessoas que criam projetos e buscam aprofundamento na área escolhida.

\section{$3^{\underline{a}}$ categoria: Na prática profissional}

No caso, a prática profissional, a prática do cuidar, foi citada pelos sujeitos desta pesquisa como condição básica para o desenvolvimento em comunicação que acontece com alunos, pacientes, docentes, equipe, etc. A operacionalização desse desenvolvimento pode ocorrer por meio de novas estratégias de ensinoaprendizado da temática e nas discussões com os envolvidos.

"Outra coisa que me levou a estudar comunicação, a tentar usar uma linguagem adequada ao nível de cada pessoa foi quando eu trabalhei na neurologia, ver aqueles pacientes epilépticos entrarem em 'estado de mal' na enfermaria, com internação, 
quase morrendo, porque ninguém (o paciente ou família) havia entendido as orientações para uso da medicação prescrita."

(E 2)

"Comecei a utilizar o que eu lia de comunicação, tanto no ensino teórico como no prático, com as alunas." (E 2)

"Tentei colocar na, prática, o que eu entendia por comunicação, fiz um estudo na comunidade; percebi que qualquer que fosse a situação onde o enfermeiro fosse atuar, ele tinha que saber se comunicar. Eu nunca me afastei da prática através do ensino."

"Na própria prática de Enfermagem, você vai aprendendo e descobre que precisa ter uma comunicação clara. Na minha atividade profissional, eu penso que procurei sempre exercer assim, desta forma. Sempre insistindo em alguma coisa que seja vinculada, incondicionalmente, a prática do cuidar. Não existe comunicação se você não tem a comunicação na prática da assistência de Enfermagem. É desenvolver a competência comunicativa na prática do cuidar." (E 6)

"Desenvolvi o aprendizado a partir da minha vivência profissional." (E 8)

"Acredito que tenho tal competência quando se trata de interação com meus clientes, alunos e mesmo com as pessoas mais íntimas, exercito-a no dia-a-dia, em sala de aula, nos hospitais..." (E 12)

"Na docência de graduação e pós-graduação, desenvolvo minha competência no decorrer do planejamento e operacionalização das estratégias de ensino-aprendizado da temática e nas discussões com as demais docentes envolvidas. Nesse processo ocorrem "insigts" que se tornam significativos e mudam meu comportamento." (E 13)

As competências que dão suporte ao exercício profissional, são construídas com base nos saberes práticos, nos conhecimentos teóricos, na experiência de vida e na socialização profissional, assim, os resultados do processo formativo podem ser mais ou menos fecundos, de acordo com a 
intensidade e a fundamentação teórica, que alicerçam a reflexão sobre as ações $^{(85,86)}$.

O que dá sentido ao processo formativo do Enfermeiro é a aplicação dos conhecimentos adquiridos, tanto em sala de aula como nas experiências preexistentes, na prática. As experiências podem ser desenvolvidas de diversas formas, desde que, na formação e no ambiente de trabalho sejam criadas condições para o desenvolvimento de competências por meio da prática.

\section{4aㅡ categoria: Desenvolvendo pesquisa e publicações na área}

O desenvolvimento da competência comunicativa também acontece pela pesquisa e publicações em comunicação. Os entrevistados explicitam uma busca constante por aprofundamento, quer seja publicando, criando disciplinas, grupos de pesquisa, desenvolvendo workshops e participando de eventos nacionais e internacionais visando a divulgar e aperfeiçoar-se na compreensão da temática.

"Continuei buscando e consegui, naquele momento, chegar a um modelo de procedimento que publiquei em livro; eu também queria um jeito de estudar mais esta questão e criei uma disciplina, muito mais do que transmitir, eu queria aprofundar e aí a partir dessa disciplina eu criei um grupo de pesquisa..." (E 5)

"Comecei a publicar trabalhos, a participar de eventos, levando trabalhos." (E 6)

"Desenvolvi três workshops sobre aquisição de habilidades comunicativas. Foi um processo muito rico, no qual a observação e discussão das entrevistas realizadas pelos alunos do curso ampliaram meus horizontes de compreensão da temática." (E 13) 
Toda competência se produz com base em um corpo de conhecimentos assimilados numa relação teórica e prática, em constante desenvolvimento e transformação. A pesquisa apresenta-se como um resultado desse conjunto de conhecimentos e da necessidade de crescimento, expansão e reformulação.

Em um estudo sobre a pesquisa como experiência educativa, as autoras ${ }^{(87)}$ propuseram-se a analisar as repercussões do ensino e prática da pesquisa, os resultados indicaram-na como experiência fundamental na formação do enfermeiro e observaram, no ato de pesquisar, certa unanimidade ao relacionar pesquisa com ações, como as de repensar, questionar, descobrir, conhecer e mudar a realidade. 


\subsection{BASES PARA O ENSINO DA COMUNICAÇÃO EM ENFERMAGEM}

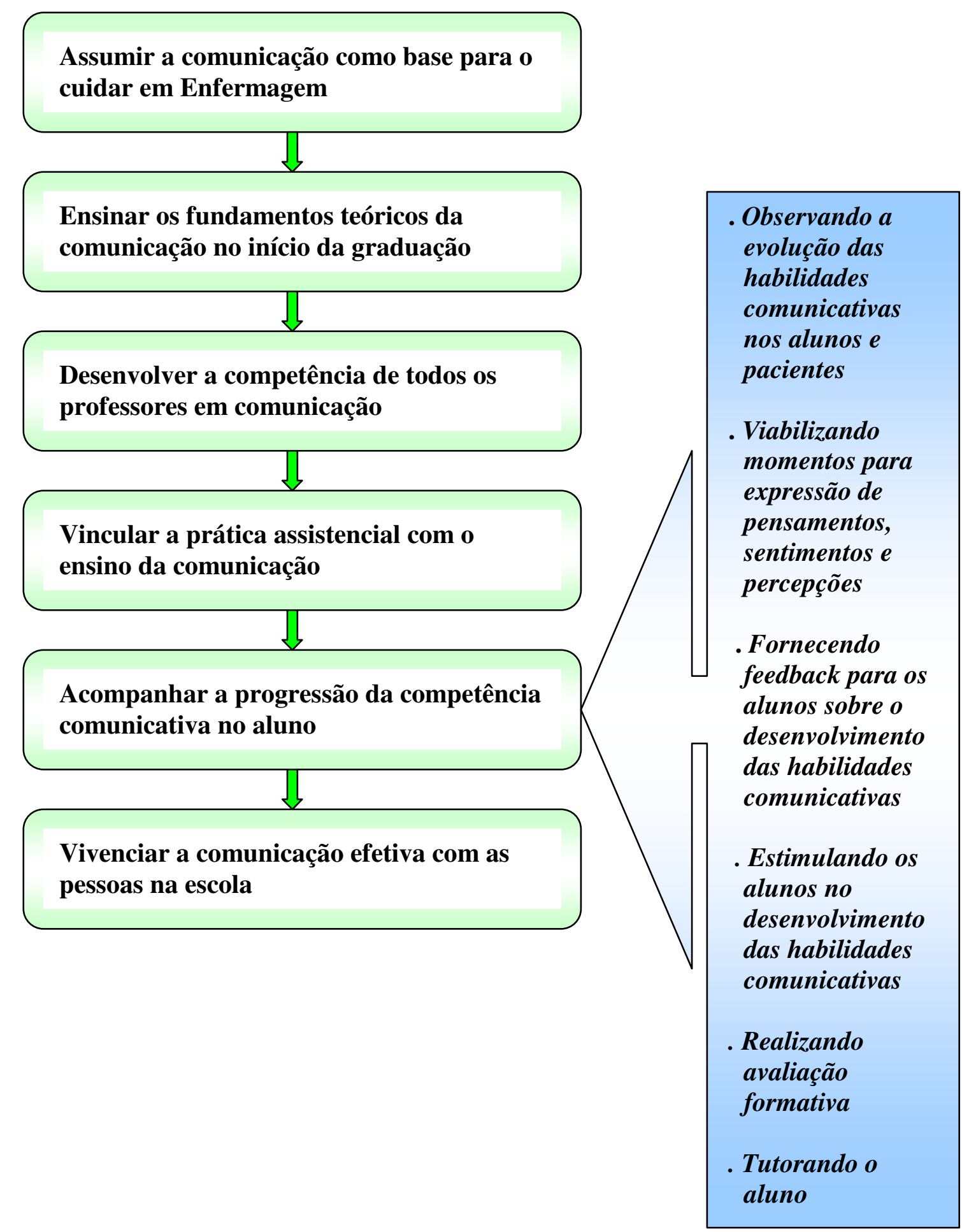


1ํㅡㄹ categoria: Assumir a comunicação como base para o cuidar em Enfermagem

A valorização do tema, comunicação como base para o cuidar, foi citada como uma importante introdução para o ensino de comunicação em Enfermagem.

Os sujeitos da pesquisa afirmam que o valor da comunicação para o cuidar deve ser demonstrado desde os primeiros contatos com os alunos; se possível, durante a aula inaugural. Demonstrar aos alunos que 0 desenvolvimento dessa habilidade é muito considerado na escola, como um despertar da consciência de que comunicar com competência é uma necessidade de todo ser humano. Destacam, também, que a valorização da habilidade comunicativa deve acompanhar toda a formação do aluno.

"Começar no primeiro contato com os alunos, até na aula inaugural tem que estar presente, não precisa dar aula sobre comunicação, mas o modo como esta aula vai ser dada tem que demonstrar para os alunos que isso é muito considerado na escola. O processo interpessoal, o processo comunicacional que se estabelece, que ocorre na escola deve ser transmitido para os alunos neste momento." (E 2)

"Que a comunicação seja apresentada para ele, desde o começo como elemento básico." (E 6)

"Despertar a consciência de que somos seres comunicativos e que a comunicação é uma necessidade de todo o ser humano." (E 7)

"Tem que ser voltado para o ensino da graduação, o enfermeiro tem que ser formado sabendo o valor da comunicação." (E 9) 
Para Watzlawick ${ }^{(21)}$, todo comportamento, em uma situação interacional, tem valor de mensagem, portanto, é comunicação e toda comunicação é um compromisso.

Ao refletir sobre a comunicação como um compromisso, concordamos com a afirmação de que o valor da comunicação ou o compromisso com a transmissão de informações precisa ser evidenciado nos primeiros contatos com os alunos e isso ficou claro nos depoimentos dos entrevistados do estudo.

Temos o compromisso de formar cidadãos livres e autônomos, sujeitos do processo educacional, professores e alunos capazes de atender as necessidades sociais da saúde, assegurar a integralidade da atenção, qualidade e humanização do atendimento do indivíduo, da família e dos diferentes grupos da comunidade $^{(31)}$. Este compromisso exige transformações, como as já explicitadas nos estudos de Belloni( ${ }^{(28)}$, De Domenico ${ }^{(29)}$, Ide e Chaves ${ }^{(32)}$ e Dell"Acqua ${ }^{(88)}$. Acrescenta-se que essas mudanças devem, necessariamente, incluir uma revisão nos valores atribuídos ao processo de comunicação no ensino de Enfermagem.

O processo do cuidar é interativo, de desenvolvimento, crescimento e ocorre de forma contínua ou em um determinado momento, mas tem o poder de conduzir a transformação. O cuidar é nossa prática, portanto, o conhecimento da Enfermagem é uma prática de cuidar que se caracteriza por ações e comportamentos, nos quais estão embutidos o espírito científico, a emoção, a sensibilidade, a destreza e a habilidade ${ }^{(89)}$. 
A capacidade para cuidar pode ser desenvolvida, despertada ou inibida por meio da experiência educacional e, sobretudo, pela presença ou ausência de modelos de cuidar $^{(90)}$

Neste sentido, o processo educacional pode desenvolver e transformar as formas de cuidar, e o ensino das habilidades interpessoais de comunicação, como base para o cuidar, precisa estar garantido na formação do enfermeiro.

\section{$2^{a}$ categoria: Ensinar os fundamentos teóricos da comunicação no início da \\ graduação}

Entendendo-se a comunicação como base para o cuidar, permeando toda a formação, os sujeitos pesquisados afirmam que os fundamentos teóricos da comunicação devem ser ensinados no início da graduação, quando o aluno inicia suas relações com os pacientes, quando começa o desenvolvimento de uma relação profissional.

"Os cursos da área de saúde deveriam incluir ou como disciplina, ou como módulo uma carga horária específica de comunicação, não de modo superficial, mas, sim, de modo aprofundado, isso deveria acontecer logo no início do o curso." (E 1)

"Tenho certeza de que devemos começar na primeira disciplina de Enfermagem." (E 2)

"Acredito que deve haver uma disciplina específica de comunicação logo no início do curso de Enfermagem, onde se abordariam questões básicas sobre o tema." (E 12)

No ensino e no cuidado, encontram-se situações bastante complexas, que exigem fundamentação teórica em comunicação, que servirá de sustentação na 
aquisição das competências necessárias ao exercício do cuidar e ou ensinar em Enfermagem.

Todos os autores, teoristas da área, afirmam e reafirmam a respeito da importância da comunicação nas interações; portanto, seja qual for o referencial teórico abordado para o ensino da comunicação, este não será contraditório.

3a categoria: Desenvolver a competência de todos os professores em comunicação

Nesta categoria, fica evidente a necessidade de todos os docentes da graduação envolverem-se com o tema da comunicação e desenvolverem as habilidades exigidas para adquirir esta competência. Os resultados sugerem que esse conhecimento não se restrinja a uma única disciplina, é importante que todas abordem a comunicação, de acordo com suas peculiaridades e que os professores aperfeiçoem-se para criar estratégias e instrumentos para esse ensino.

É responsabilidade dos docentes especializarem-se em habilidades comunicativas e permitirem que outras pessoas também possam adquirir esse conhecimento, e isso deve ser apresentado em todos os âmbitos possíveis.

Outra proposta a esse ensino é que os docentes devem avaliar a impacto de sua comunicação com o outro e estimular os alunos para esta reflexão.

"Que cada professor, ao longo de sua disciplina, possa articular juntamente com o aluno os conhecimentos aprendidos no início do curso". (E 1)

"Que todos os docentes da escola conheçam o assunto, isso é fundamental e não, quando o aluno faz uma pergunta sobre 
comunicação, ouvir: "você vai lá na psiquiatria ou no departamento tal, ou fale com alguém de fundamentos que eles estudam instrumentos básicos..." (E 2)

"O ensino e a aprendizagem de comunicação não devem se restringir a uma só disciplina, em todas as disciplinas do curso, tanto teóricas quanto as práticas, deve estar permeado o ensino do tema, destacando as peculiaridades de cada área." (E 12)

"Que o planejamento deste tema seja discutido pelo coletivo dos professores para que os mesmos possam perceber que quase tudo pode ser compreendido enquanto uma faceta do processo de comunicação, mas falta ligar estas perspectivas, para que tomem forma e direção." (E 13)

"Proponho que as pessoas usem a imaginação e criem estratégias de ensino de comunicação, eu acho que é com estes instrumentos que a gente cresce também. Criar instrumentos é importante porque você tem que ter algo formalizado, algo que você possa validar, avaliar. A gente deve elaborar, guiar, é responsabilidade nossa ter estes elementos de comunicação validados para que outras pessoas possam usar." (E 2)

"É importante que as pessoas adquiram o conhecimento das habilidades de comunicação, isso precisa ser apresentado em todas as instâncias." (E 3)

"Quantos de nós paramos para fazer uma reflexão do impacto do que nós estamos fazendo? Isso tem que ser ensinado, ser resgatado. O nosso ensino tem que ter tempo para esses exercícios. Esse eu acho que é uma propositura para o ensino de comunicação." (E 9)

A competência integra vários saberes e habilidades: são atitudes e posturas mentais, curiosidade, paixão, busca de significado, desejo de tecer laços, relação com o tempo e maneira de unir intuição e razão, cautela e audácia, que nascem tanto da formação como da experiência ${ }^{(25)}$. Esta rede de relações faz da construção de competências uma forma de enfrentar problemas e superá-los, 
reconstruindo uma expressão profissional em um ensino renovado de Enfermagem ${ }^{(91)}$.

No estudo sobre o significado de competência para o docente de administração em Enfermagem, emergiu a categoria: "saber fazer bem: a consciência e a prática profissional", cuja autora explicita que todos os professores traduzem como saber fazer bem, um saber articulado a conhecimentos e suas habilidades de transmissão, além das atitudes que envolvam e estimulem o aluno para o próprio desenvolvimento ${ }^{(92)}$.

Gadotti $^{(15,93)}$ afirma que a relação professor-aluno é base de toda reflexão sobre educação. Na prática da educação, o educador educa-se, ele precisa se educar com cada educando e isso exige um esforço constante de atenção e renovação de si mesmo.

Sob este aspecto, é recomendável que o tema da comunicação seja de domínio do grupo de docentes, isto é, seja planejado em conjunto, baseado em um amadurecimento do grupo e da significação que cada docente atribui ao assunto. Este planejamento precisa ser embasado na abertura, no respeito e no compartilhar de informações, sempre percebendo o outro e encorajando a participação de todos ${ }^{(94)}$.

\section{4a categoria: Vincular a prática assistencial com o ensino da comunicação}

Os entrevistados afirmam que o ensino de comunicação deve ser vinculado à prática de todas as áreas. É discutir e aprender com momentos 
vividos, considerando as experiências anteriores dos alunos, além de propiciar exercícios que possibilitem vivência e até autoconhecimento.

O ensino vinculado à prática permite ao aluno o desenvolvimento das habilidades propostas, como respeitar o paciente, sua família, colegas, profissionais da equipe e a si mesmo, reconhecendo, em cada momento, as oportunidades de utilizar na prática as habilidades apreendidas.

"Utilizar os momentos vividos para discutir o ensino de comunicação terapêutica, inclusive de professor-aluno. Estamos trabalhando com adultos, é ideal que se parta da vivência, da experiência deles. A gente deve aproveitar tudo o que acontece numa relação de sala de aula, de família, num aglomerado de ambulatório, de hospital, etc." (E 2)

"A teoria isolada da vivência tem pouca fixação. Isso eu percebi no meu estudo, depois exercitando na prática você vê que isso procede mesmo. Não adianta dar só teoria, eu tenho que propiciar exercícios que possibilitem a vivência dessa pessoa e, de certa forma, até o autoconhecimento." (E 3)

"O aluno sai diferente depois de uma vivência." (E 5)

"Eu acredito muito na vivência, eu acho que é uma estratégia para você desenvolver sua habilidade de comunicação, claro que quando há um embasamento teórico, facilita, mas você tem que vivenciar." (E 8)

"Eu proponho o desenvolvimento de habilidades, ensinar o aluno a entender, quando ele tem que fazer silêncio. Quando ele tem que respeitar o silêncio do paciente e, alguém tem de estar alerta para estas técnicas, no modelo que for, na abordagem que for. O fato de eu sentar ao lado do paciente ou permanecer de pé, isso é diferente na hora em que eu falo. Eu posso entender comunicação, como um grande processo, mas eu tenho que entender que ela tem efeito no outro. Eu tenho que ter consciência disso, ter consciência do papel de autoridade que o profissional tem, se quer usar essa autoridade ou se ele quer abrir mão dessa autoridade. Se quer fazer uma negociação de autoridade; é esse tipo de limite e do poder que a comunicação tem, o poder positivo, porque, às vezes, ele é maléfico, você o usa de uma forma maléfica, mas se você souber que isso tem 
poder, não é neutro, não é isento de força, isso precisa ser trabalhado e mostrado, mostrado assim como conseqüência mesmo como, por exemplo, dizendo: olha, nesta situação, existem outras alternativas!" (E 9)

"Que seja um tema transversal na graduação, que permeie o processo de formação dos profissionais, com momentos específicos e momentos interdisciplinares, que focalize a auto percepção, 0 auto conhecimento, 0 desenvolvimento de habilidades interpessoais, de negociação, de enfrentamento de conflito." (E 13)

Todo conhecimento deve ser estruturado na prática e para a prática. Ao perceber, na prática, as manifestações verbais e não-verbais dos pacientes, dos familiares, da equipe e as próprias, a aluno faz a transferência dos conhecimentos adquiridos e inicia o processo de interpretação da comunicação e suas conseqüências. Desta forma, as palavras expressas ou escritas serão, gradativamente, vinculadas aos gestos, posturas, expressões faciais, orientações do corpo, singularidades somáticas naturais ou artificiais, organização dos objetos no espaço e a relação de distância mantida entre os indivíduos.

Para que a transferência de conhecimentos ocorra, é importante respeitar as experiências prévias dos educandos, pois estas revelam o mundo cultural e social que vem se constituindo, mostram também o trabalho individual de cada sujeito no próprio processo de assimilação desse mundo ${ }^{(60)}$.

Em sua história e projetos pessoais, nem todos os alunos encontrarão chaves para imaginar situações, nas quais possam mobilizar o que aprendem, é preciso criar espaços e tempo, definir regras do jogo que autorizem os alunos a evocar o que esta aprendizagem significa para eles ${ }^{(95)}$. 
No estudo de Dell"Acqua ${ }^{(88)}$, os resultados revelam uma aprendizagem voltada à execução metódica das práticas, escolhidas pelos docentes, ou seja, a seqüência do ensino-aprendizagem teria uma intenção e uma preparação definidas pelos professores. Ainda, a ligação das atividades de ensino promovendo poucas iniciativas de integração consciente, com intervenções, às vezes, distantes da realidade dos alunos, aparentemente, desconsiderando interesses, questionamentos e experiências significativas para eles.

5a categoria: Acompanhar a progressão da competência comunicativa no aluno

Os entrevistados destacam que o acompanhamento da progressão da competência comunicativa do aluno ocorre, observando a evolução das habilidades comunicativas nos alunos e pacientes; viabilizando momentos de expressão de pensamentos, sentimentos e percepções, fornecendo feedback sobre o desenvolvimento das habilidades comunicativas; estimulando-os ao desenvolvimento das habilidades em comunicação; realizando avaliação formativa e tutorando o aluno.

Subcategoria 1: Observando a evolução das habilidades comunicativas nos alunos e pacientes

A observação da evolução das habilidades no dia-a-dia das relações interpessoais, a evolução dos pacientes, o interesse que demonstram pelo outro, 
as situações que surgem, mostram sua própria evolução e segurança como aluno.

"Observando, estando junto na hora das interações com os pacientes." (E 1)

"A gente observa essa progressão no dia-a-dia das relações, não só com o paciente, mas com o colega e com outros profissionais da equipe." (E 4)

"Através da evolução dos pacientes, de quando começou a ser cuidado, de repente ele vai se transformando ou os alunos vão ficando mais seguros e todas as questões vão sendo trabalhadas." (E 6)

"Pelo interesse que demonstram pelo contato com o outro, a forma de expressar-se com o outro, o cuidado que têm no sentido de provocar efeitos positivos..." (E 7)

"No dia-a-dia com o aluno a gente vê a questão da comunicação, a questão técnica, quer dizer a gente vê tanto a as habilidades humanas, como a interação, a comunicação, a liderança. Então a gente vê o fazer a ponte da teoria com a prática, incluindo a técnica também. Essa progressão é no dia-adia, nas nossas atividades teórico-práticas, no hospital e aqui, na sala de aula." (E 8)

"Estando atenta às perguntas que o aluno faz, ali na cabeceira quando ele está começando, trocando a cama ou encaminhando o paciente para o banho. Se você perceber que o aluno faz quatro perguntas em seguida, e o paciente não consegue respirar para responder nenhuma, é hora de você intervir, é hora de mostrar, talvez, não na frente do paciente, mas é hora de mostrar, num momento adequado que ele deve esperar o paciente responder cada uma das perguntas ou, então, perguntar ao paciente se ele está em condições de responder às perguntas do aluno." (E 9)

"Observo o desempenho de cada aluno na interação com os pacientes, familiares, profissionais de saúde e colegas de turma." (E 13) 
Dentre as dez competências para ensinar, apontadas por Perrenoud ${ }^{(16)}$, uma delas é "administrar a progressão das atividades" e a autor indica como uma das formas, o observar e avaliar os alunos em situações de aprendizagem. Afirma que para gerir a progressão das aprendizagens, não se pode deixar de fazer balanços periódicos das aquisições dos alunos, que nada substituem as observações dos alunos no trabalho, quando o objetivo é conhecer suas competências. É importante que o professor saiba determinar, interpretar e memorizar momentos significativos que contribuem para estabelecer um quadro de conjunto do aluno às voltas com diversas tarefas. É evidente que a observação contínua não tem apenas a função de coletar dados, sua primeira intenção deve ser formativa.

\section{Subcategoria 2: Viabilizando momentos para expressão de}

\section{pensamentos, sentimentos e percepções}

O resultado deste estudo mostra que, mais do que ouvir o aluno, os docentes precisam viabilizar momentos para a expressão dos sentimentos, pensamentos e percepções. Docentes e alunos necessitam desses momentos, em que a utilização das habilidades comunicativas ou a falta delas vão sendo mostradas e, nessa relação e ou interação, os indivíduos vão se conhecendo e amadurecendo mutuamente.

"Eu solicito ao aluno que escreva sobre um momento em que ele estava cuidando e sentiu muita ansiedade. Peço que o analise ou um momento em que percebeu ansiedade no paciente. Isto para que ele perceba bem a situação, porque o aluno não tem aquela coisa de achar que você vai estranhar o que ele fala. $O$ profissional já teria. $O$ aluno não tem que provar nada, inclusive, numa disciplina como essa, é 
interessante você deixar tudo muito aberto, o aluno fala o que ele acha, fala e expressa sem medo ou vergonha, não se preocupa se a professora vai dar nota baixa porque ele falou que ficou ansioso ou ficou com raiva. Os alunos falam livremente, é aconselhável criar um clima sem crítica, pois quando o aluno começa contando, tal médico, tal enfermeira, tal auxiliar, enfim, a se posicionar, eu falo: primeiro de tudo, nós não estamos aqui para criticar nem para fazer isso com ninguém, certo?. Cada pessoa faz como pode; falo isso para banir um pouco essa coisa de crítica, especialmente, a negativa. Banir um pouco isso de crítica, de certo, de errado. Não é simples, mas quando você se propõe, você consegue. A partir do que ele relata e algumas vezes, eu noto que a turma está estressada, agitada, eu paro a aula, suspendo a aula e a gente vai tratar daquelas questões. Esse é o momento em que aparece o retorno que é possível ter, do aprendizado. Às vezes, o aluno fala: "professora é difícil, não consigo", eu falo: é, mas vamos tentar, se hoje você não consegue, na próxima vez você vai pensar nisso que não deu certo e vai tentar e é assim que se aprende. Acho que é dessa forma." (E 6)

"Por exemplo, estimular o aluno a falar como ele se sente, tem uma aula que eu dou sobre auto-expressão, não se fala autoconhecimento, não chega a tanto, é uma dinâmica de grupo em que os alunos falam sobre si mesmos, coisas que eles jamais falariam num contexto onde houvesse autoritarismo, não mesmo!" (E 6)

O exercício da competência está atrelado aos valores humanos, princípios e ideais éticos que refletem o compromisso da profissão com ações dotadas de tolerância e respeito de todos os gêneros. Uma ação competente agrega perspicácia e vigilância por parte do profissional, visto que existem condições sociais, culturais e familiares influenciando uma prática que deve ser dotada de cidadania, solidariedade e justiça, portanto, a qualidade da comunicação e das relações, certamente, alicerça o exercício da competência ${ }^{(29)}$.

A habilidade em comunicação é, especialmente, importante quando se trata de viabilizar momentos de expressão de pensamentos e sentimentos. A comunicação verbal mostra que a as palavras são importantes ferramentas de 
contato, são usadas de modo mais consciente, mas sabemos que o ato de falar é complexo, pois influencia o relacionamento entre as pessoas.

Sob este aspecto, Satir ${ }^{(42)}$ afirma que é muito importante saber usar bem as palavras, indica para prestar atenção no que dizemos e perceber se, realmente, é o que queremos transmitir, pois ao usarmos as palavras com cuidado, estaremos evitando muitos desentendimentos.

No entanto, está comprovado que existe uma relação dialética entre a palavra e o não-verbal. Segundo Gaiarsa ${ }^{(96)}$, a idéia comum é que só o mundo verbal é real, entretanto as palavras são, tantas vezes, apenas um pretexto ou um começo. Quanto menor a dissociação entre fala e expressão, mais integrada e inteira será a pessoa.

Em estudos realizados na psicologia social, a expressão do pensamento se faz $7 \%$ com palavras, $38 \%$ com sinais paralingüísticos (entonação de voz, velocidade da fala, entre outros) e $55 \%$ por meio dos sinais do corpo ${ }^{(11)}$.

Desta forma, a comunicação não-verbal é responsável por mais de $90 \%$ dos sinais que chegam ao cérebro por meio dos sentidos da visão, do toque, da audição e da respiração.

Para que possamos perceber a expressão dos pensamentos e sentimentos do outro, Moscovici ${ }^{(4)}$ indica o desenvolvimento da competência interpessoal, que é a habilidade de lidar, eficazmente, com as relações interpessoais, lidar com as outras pessoas de forma adequada às necessidades de cada uma e às exigências da situação. 


\title{
Subcategoria 3: Fornecendo feedback para os alunos sobre 0
} desenvolvimento das habilidades comunicativas

Os docentes entrevistados citam a importância de se fornecer um retorno avaliativo, um momento para feedback no qual os professores explicitam ao aluno como estão sua comunicação verbal e a não-verbal e o que pode ser melhorado. Os entrevistados relatam que o próprio aluno, nesses momentos, faz uma auto-avaliação de suas interações.

\begin{abstract}
"Fazendo reuniões no final do período do estágio para ver quais as dificuldades, contar para o aluno no que ele pode melhorar na comunicação verbal ou não-verbal. Ouvindo o que ele tem a dizer sobre suas dificuldades, do que ele está enfrentando de dificuldades na comunicação. É muito comum acontecer de o aluno tomar contato com muitas coisas dele, de fazer uma autoavaliação mesmo, muito mais do que eu ficar avaliando e aí termos que dar um suporte para o aluno pela questão do autoconhecimento." (E 1)

"Dou o feedback, discutimos em pequenos grupos. No final, peço a auto-avaliação qualitativa referente ao desempenho na relação interpessoal, com base nas referências básicas estudadas anteriormente $e$ aconselho aqueles que tiveram dificuldades importantes. Darei exemplo: detectei alunas com timidez extrema, ofereci suporte e percebi que necessitavam de ajuda profissional. Da mesma forma, alunos extremamente ansiosos, autoritários, passivos/ submissos." (E 13)
\end{abstract}

O estudo sobre os obstáculos de comunicação, encontrados entre enfermeiros, revela que existem dificuldades em dar feedback, em demonstrar sentimentos e emoções, desencontros de informações e conflitos, entre outros, o que confirma a falta de investimentos no ensino de habilidades comunicativas aos enfermeiros ${ }^{(97)}$.

A capacidade de dar e receber feedback permite a construção de relacionamentos autênticos, evidentemente, esta habilidade de percepção precisa 
de treino, exigindo coragem e disponibilidade, e um longo processo de crescimento pessoal.

Nas palavras de Silva ${ }^{(11)}$ :

"Lembremos que dar feedback envolve auto-exposição, ou seja, revelar ao outro o que o seu comportamento nos causa em termos de pensamentos e emoções. Buscar feedback consiste em solicitar e estar aberto para receber as reações dos outros, também, em termos de pensamentos e emoções, demonstrados de maneira verbal e não-verbal, em relação ao nosso comportamento".

\section{Subcategoria 4: Estimulando os alunos no desenvolvimento das}

\section{habilidades comunicativas}

Os alunos precisam de estímulo, de dinâmicas diversas em sala de aula e de apoio teórico por meio de leituras para o desenvolvimento das habilidades comunicativas. O registro das interações, para posterior análise, foi citado como um importante parâmetro desse desenvolvimento.

"Trabalho teoricamente, estimulando a leitura, fazendo dinâmicas em sala e tentando estimular a participação do aluno, procuro usar técnicas de comunicação verbal e não-verbal para tentar estimular o aluno para que ele chegue no campo de estágio um pouco mais receptivo." (E 1)

"Eu uso bastante, como recurso a dramatização, role playing, coisas assim, mas principalmente estimulo os alunos a utilizarem na prática e trazerem registro de interação." (E 6)

Como descrito em nosso referencial teórico ${ }^{(11,37,38)}$, a motivação é fator fundamental para a aquisição da habilidade comunicativa, especialmente, a não- 
verbal, pois implica querer tornar consciente muito da linguagem inconsciente. A motivação aumenta quando percebemos os afeitos dessa habilidade na vida pessoal e profissional.

Competência é a capacidade de mobilizar todos os tipos de recursos cognitivos, não é um saber procedimental codificado, que pode ser aplicado literalmente. Ela mobiliza saberes declarativos, que descrevem o real, procedimentais, que prescrevem o caminho a ser seguido, e condicionais que dizem em que momento se deve realizar determinada ação ${ }^{(86)}$.

Perrenoud $^{(86)}$ cita que mobilizar, seriamente, as competências é um ato demorado que exige situações de formação mais criativas e complexas que as alternâncias entre aulas e exercícios. Um adulto pode aprender sozinho por meio de reflexões pessoais e de leitura, é preciso não o deixar dependente do formador, mas é necessário acelerar seu processo de autotransformação por intermédio de uma prática reflexiva contextualizada, com fundamentos teóricos e conceituais. O desenvolvimento das competências está no cerne da profissão do formador que tem o aprendiz como o centro, assim, observa-o, chama a atenção, sugere e motiva, sempre tentando estimulá-lo e não o controlar.

\section{Subcategoria 5: Realizando avaliação formativa}

Os resultados deste estudo mostram ser importante a realização da avaliação formativa para a percepção da evolução dos alunos, cuja realização deve ser explicitada em seus objetivos, logo no início de cada atividade. 
que ele pense na possibilidade de desenvolver o vínculo com o paciente, a confiança, porque na saúde mental ele não vai conseguir se comunicar nunca, se não tiver isso. Então, que ele pense que esta avaliação, apesar de subjetiva, vai estar acontecendo.Também avalio a evolução dele, de quando ele começa o estágio e de quando ele termina. A gente faz uma prévia no primeiro dia e no último dia, ou seja, como ele entrou e como ele está saindo." (E 1)

"Faço uma avaliação no final da disciplina onde eu pergunto e o aluno me responde, bastante livre, mas eu dou todos os tópicos sobre o conteúdo, sobre condução desse ensino, sobre o que ele aprendeu, sobre o que foi importante nesse aprendizado, quer dizer, faço uma avaliação com roteiro e, eu já fiz várias vezes, um acompanhamento dos alunos depois de um tempo. Têm dois ou três, três trabalhos publicados acompanhando essa avaliação." (E 5)

A aprendizagem é um processo contínuo e uma avaliação consciente, deve levar em conta o progresso que o aluno revela no uso e conexões, no emprego de habilidades, no poder de construir novas contextualizações e na sensibilidade para perceber linguagens diferentes ${ }^{(98)}$.

Na concepção construtivista, uma avaliação formativa é contínua e tem como finalidade fundamental a formação integral da pessoa, compreende observar as diferentes fases experimentadas na construção das habilidades desejadas pelos alunos e professores.

No processo de avaliação formativa, são consideradas as seguintes fases $^{(25,29,99)}$ :

- avaliação inicial: aquela que permite conhecer qual é a situação de partida, em função de objetivos gerais bem definidos, bem como conhecer o que cada aluno sabe, o que quer 
saber, quais os instrumentos que já dispõe e quais as limitações já vivenciadas;

- avaliação reguladora: parte dos objetivos e conteúdos de aprendizagem previstos, o professor estabelece as atividades e as tarefas e vai percebendo a maneira como cada aluno aprende e as necessidades de aprendizagens ou alterações que podem ser realizadas;

- avaliação final: analisa-se o desempenho do aluno, ou seja, se ele atingiu os resultados, se adquiriu as competências desejadas. O progresso de cada aluno sempre será analisado em relação aos objetivos propostos;

- avaliação integradora: professor e aluno devem discutir a respeito do que foi desenvolvido e realizar previsões sobre o que é necessário continuar fazendo ou refazer. Esta etapa é importante para que o aluno possa continuar sua formação, considerando suas características específicas. 


\section{Subcategoria 6: Tutorando o aluno}

Os resultados das entrevistas mostram que o aluno precisa ser cuidado pelo professor, isto é, a comunicação, como base prática do cuidar, deve ser ampliada ao aluno para que ele possa evoluir em seu aprendizado.

Os relatos afirmam que o docente deve ensinar no modelo e na convivência, evidenciando, a ação da competência em comunicação na prática. O professor precisa proteger o aluno, expondo o lado positivo das interações, mesmo que tenham ocorrido falhas. Esta proteção pode se estender até, se for o caso, com interferência em uma interação que não tem condições de continuar.

"A gente tenta fazer um acompanhamento individualizado deste aluno, até mesmo fazendo o papel de alguém que está cuidando deste aluno, para que ele tenha condições de ultrapassar essas barreiras e aprender um pouco mais sobre isso." (E 1)

"Ensinar na convivência, ensinar no modelo, ensinar na cobrança da forma. Quantas vezes você chega para um aluno e fala: olha o tratamento, você não tem condições de continuar. Tirar o aluno de cena e mostrar para ele que ele pode melhorar em muito a relação e voltar de uma forma engrandecida. Nem sempre tirar um aluno é punir, muitas vezes é proteger. Você consegue, às vezes, dar exemplos para aquele que está direto com você, chamar atenção. É mais fácil identificar os desvios do que as situações positivas. Às vezes falta reforço da conduta correta para ele (o aluno) se sedimentar. É bom você dizer, olha você teve uma conversa interessante com seu paciente, no final aconteceu isso ou aquilo, mas pensa nesse lado positivo. A gente não faz isso com o aluno. O nosso ensino é aversivo, hostil." (E 9)

A orientação do aluno é papel do educador, expressa o cuidado com sua aprendizagem e deve libertar, sem abandoná-lo. Orientar é convidar à emancipação, e esta é uma situação humana de extrema complexidade, pode ser muito efetiva, até mesmo rápida, como pode se perder no tempo e jamais se realizar. 
Nas palavras de Demo ${ }^{(100)}$ :

"Perscrutar as motivações do aluno, entender seus anseios, tocar as cordas corretas da emoção, provocar sem oprimir, admoestar sem imbecilizar, é fina arte, sensibilidade sutil, perspicácia a toda prova. Tem sempre a vantagem de evitar o tratamento unificado de pessoas tão diversificadas, provocando contextos mais flexíveis e alternativos de socialização."

\section{6aㅡ categoria: Vivenciar a comunicação efetiva com as pessoas na escola}

Os resultados do estudo impõem a necessidade de um ensino mais vivo, vivenciado, que seja aplicado no dia-a-dia da escola, nos corredores, na portaria, na biblioteca, no refeitório, etc. Que docentes, professores, alunos e funcionários mantenham uma comunicação efetiva em todas as experiências interativas, isto é, que a competência em comunicação e seu desenvolvimento estejam explícitos nas relações interpessoais da escola.

"O professor tem que aprender, o professor e o aluno, que comunicação não se aprende só em sala de aula. Não adianta trabalhar o tema comunicação e no horário do almoço, o professor passar pelo aluno como se ele não existisse. Comunicação tem que permear a vivência da pessoa dentro da escola, vivência do processo terapêutico comunicativo. O que eu proponho para o ensino é um ensino muito mais vivo e vivido." (E 2)

Morin(101) afirma que "ensinar a compreensão" é uma necessidade à educação do futuro, que se tornou crucial para os humanos, é uma condição para a garantia da solidariedade intelectual e moral da humanidade. Compreender 
inclui, necessariamente, empatia, identificação e projeção, além disso, pede abertura, simpatia e generosidade. É aprender e reaprender incessantemente.

Compreender é comunicar, porém saber comunicar não garante a compreensão, isto é, uma informação bem transmitida pode fornecer conhecimento e até a aquisição de competência, mas não significa a aplicação desse conhecimento na prática. Compreender é entender, perceber, ouvir o outro e, assim, fornecer espaço, oportunidade de expressar opiniões, pensamentos, sentimentos, enfim, compreender é respeitar o outro.

O ensino de Enfermagem deve se responsabilizar pela transmissão e pela prática das habilidades comunicativas no cotidiano dos ambientes de ensino, mais do que isso, os professores de Enfermagem, competentes em comunicação, precisam ser modelos de expressão comunicativa nesses ambientes. 


\subsection{O GANHO COM A COMPETÊNCIA COMUNICATIVA}

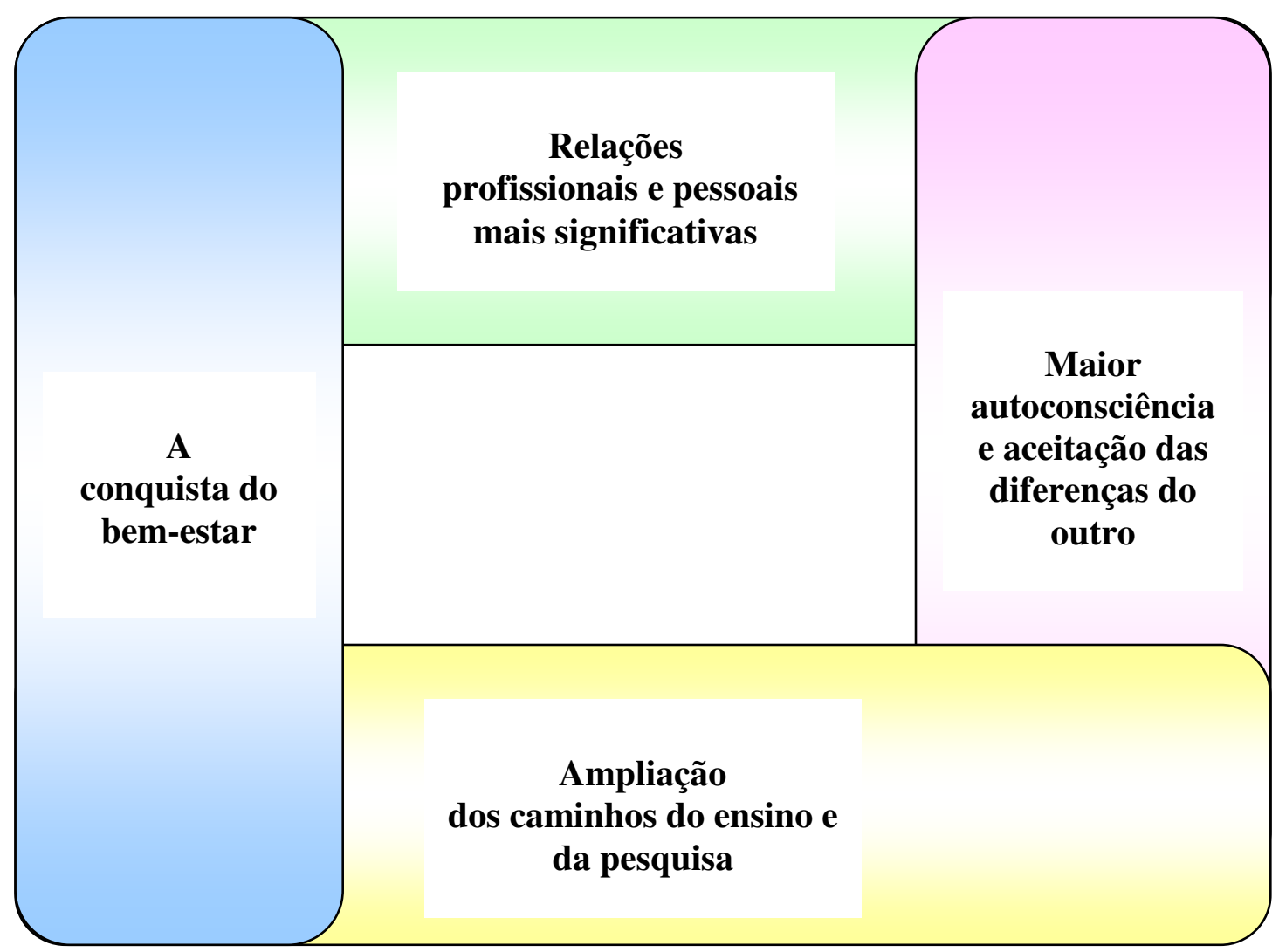


APRESENTAÇÃO DOS RESULTADOS E ANÁLISE DOS DADOS

\section{$1^{\text {a }}$ categoria: Relações profissionais e pessoais mais significativas}

Os entrevistados afirmam que conseguem estabelecer um relacionamento mais eficaz com as pessoas e, em conseqüência, verificar um ganho na qualidade das relações, ou seja, as relações tornam-se significativas. Ressaltam que é um ganho pessoal e profissional, em que há um tempo e um espaço para ser ouvido e receber a atenção merecida e, nesta condição, até os malentendidos são discutidos abertamente.

As pessoas competentes em comunicação apresentam mais oportunidades de desenvolvimento e de transformação, expressam-se melhor nas relações interpessoais, pois a competência comunicativa imprime o desafio da melhora, tanto na comunicação externa como na interna.

"Eu acho que eu ganho, primeiro no nível profissional, que eu consigo estabelecer um relacionamento com as pessoas, um relacionamento mais eficaz. No ensino, eu consigo ter um desempenho que, para mim, é satisfatório. Na assistência, eu consigo também, vislumbrar que ela acontece com mais qualidade, quando eu estou fazendo isso com empenho." (E 1)

"É uma força muito grande que permite desenvolver o grupo, conferir qualidade àquilo que se faz e, no nível pessoal, na família, dá trabalho, dá trabalho parar para ouvir, prestar atenção, mas eu acho que faz você ter relações cheias de significado. Não estamos só convivendo aqui, estamos tendo, realmente, uma relação e, então, que ela tenha um significado." (E 3)

"As relações são muito difíceis, qualquer tipo de relação, não só pessoal, na relação profissional, muitas vezes, a gente se expressa mal. Eu acho que a competência na comunicação vai diminuir estas situações, o que se ganha quando se tem competência em comunicação, é a diminuição de malentendimentos de uma relação, tanto pessoal quanto profissional; se ganha uma relação melhor." (E 4)

"É um ganho profissional, um acréscimo de habilidades e competências para exercer o papel que eu tenho, na disciplina, como orientadora, trabalhando com profissionais, eu procuro exercer essa competência colaborando neste sentido, quer 
dizer, no aspecto profissional e também no aspecto pessoal, você se desenvolve como pessoa, tem aquela visão de que está em constante transformação e desenvolvimento, imagino que sempre para frente e, sem dúvida, uma competência comunicativa faz um papel não só na comunicação externa, como na comunicação interna." (E 6)

"Olhando lá, eu como professora, e hoje, no sentido de quando eu realmente tive oportunidade de estudar um pouco de comunicação, acho que eu ganhei. Hoje, eu consigo me comunicar de uma forma mais adequada, no sentido de ouvir mais, eu não sou de falar muito. Gosto de ouvir mais as pessoas e acho que ganhei na melhoria da minha relação profissional, com meus colegas, com os alunos, ter esta habilidade de comunicação, é um ganho no dia-a-dia mesmo." (E 8)

"Novas oportunidades de trabalho surgem, têm surgido por conta deste meu direcionamento profissional para o estudo da comunicação." (E 1)

O referencial de Silva ${ }^{(11,37,38)}$ pressupõe que, ao interagirmos verbalmente com alguém, estamos transmitindo, clarificando ou validando a compreensão de algo. Na comunicação não-verbal, podemos complementar, contradizer e substituir a comunicação verbal e demonstrar sentimentos por meio de gestos, informações posturais, faciais, do corpo, singularidades somáticas, organização dos objetos no espaço e relação de distância mantida entre os indivíduos.

Além disso, a competência em comunicação permite perceber os fatores que influenciam na percepção da comunicação, como a motivação, emoções, expectativas, estereótipos, experiências anteriores, reconhecimento de sinais, conhecimento do emissor, tempo do estímulo, limitações físicas, ruídos, etc.

O ensino da Enfermagem tem o compromisso de reconhecer a comunicação, como uma forma de humanização e estudos nesta área mostram situações interpessoais influenciando na formação do enfermeiro, citamos alguns:

- o estudo sobre aspectos relacionados à comunicação professoraluno no desenvolvimento do estágio supervisionado, nos quais os 
resultados negativos, quantificados em mais de $80,0 \%$, são atribuídos às dificuldades que os professores têm para enfrentar o despreparo dos alunos ao vivenciarem o primeiro contato com a prática, e o aluno atribui à comunicação professor-aluno grande parte de suas angústias e ansiedades. As respostas positivas, quantificadas em pouco mais de $19,0 \%$, apontam para a presença solidária do professor, como mediador do processo ensinoaprendizagem e a abertura para o diálogo ${ }^{(102)}$.

- Para Melo ${ }^{(103)}$, o estudo da observação de uma sala de aula da universidade, permite desvelar um mundo de gestos, expressões e ações. Nas palavras da autora:

"a rede de comunicação traçada pela direção dos olhares de alunos e professores; o modo como se realizam, as circunstâncias em que ocorrem, as freqüências com que se dão as entradas e saídas de professores e alunos, durante a aula, respeitado o horário estipulado ou fora dele. O aluno que se assenta estrategicamente junto à porta e que, de repente, desaparece da nossa vista; que se retira tão logo outros o fazem, como a seguir, na sombra, a "trilha" aberta por outros; aquele que disfarça sua retirada da classe realizando por etapas o transporte de seus pertences ou velando-os de alguma forma; o que, ao chegar atrasado numa aula, se esgueira, para dentro dela, furtiva e sorrateiramente. Durante a aula, as posturas adotadas pelo professor, a mão no queixo tão freqüentemente observada 
nos alunos..., estes utilizam uma manobra de encobrimento para perguntar o que desejam saber, já o professor, de forma mais ou menos velada, participa a seu modo da mesma manobra de encobrimento. Dessa forma, ambos se tornam cúmplices nesse diálogo. O professor se contenta em ter alunos que cumpram minimamente o desejado desde que declinem de grandes exigências. Aplacam-se os ânimos, mas, ao mesmo tempo, instaura-se uma espécie de morte na relação.A sala de aula é também uma fonte de vestígios: disposição das carteiras, espaços de ordem ou desordem, de limpeza ou sujeira, de lixo, de pontas de cigarro, a disposição espacial e preferencial de professores e alunos, o movimento que realizam no interior dessa, os lugares "sagrados" e "profanos..."

- $\quad$ O estudo que realizou um programa de treinamento de comunicação não-verbal para a equipe de enfermagem, pautou-se nos preceitos da reforma psiquiátrica e no programa de treinamento de Silva ${ }^{(37)}$, mostra resultados de aumento no conhecimento sobre a comunicação não-verbal e sobre a reforma psiquiátrica. Os enfermeiros participantes percebem que a absorção desses conhecimentos provoca mudanças na prática cotidiana que podem melhorar a qualidade da assistência. Segundo a autora, com base nos resultados obtidos o uso da comunicação não-verbal de modo consciente é um dos instrumentos que possibilita à equipe de Enfermagem avançar na consolidação de ações coerentes, e a 
humanização torna-se, então, uma prática verdadeiramente vivenciada $^{(104)}$.

\section{$2^{a}$ categoria: Maior autoconsciência e aceitação das diferenças do outro}

A autoconsciência e aceitação das diferenças do outro aparecem como um ganho da competência comunicativa e os sujeitos do estudo relatam que, conforme haja uma busca e um aprofundamento no tema, a pessoa vai se conhecendo melhor, percebe o feedback nas relações, e se sua abordagem foi boa ou ruim, assim, as relações vão ficando mais acentuadas, mais estruturadas e as pessoas mais unidas.

Os entrevistados ressaltam que o autoconhecimento é um processo, assim como é aceitar que o outro é diferente. Afirmam que este processo é gradativo, exige muito exercício de tolerância, também permite o aprendizado e o respeito a si próprio e ao outro.

"Ajuda muito no meu autoconhecimento, cada vez que eu estudo mais, que eu estou em contato com a comunicação, isso me ajuda a me conhecer melhor, quando eu tenho o feedback das relações que eu estabeleço, me ajuda a entender quem eu sou, este momento que eu vivo, como já falei, tudo é uma coisa maior, tudo está conectado, tudo ligado."(E 1)

"Às vezes, eu tentava não demonstrar o quanto algo me irritava, dependendo do que aluno estava falando, de quem era o aluno, mas eu dava liberdade para eles falarem, porque eu acho que eu tinha que apreender como eu era, como elas me viam, como eu estava sendo vista pelo outro. Podia até ficar com raiva na hora, mas depois eu pensava: Por quê ela está falando isso? 0 que eu estou fazendo? Acho que isso é o que todo ser humano deve fazer, uma reflexão. Se ela está fazendo isso é porque eu devo estar péssima para me relacionar com os outros. Eu devo estar fazendo a coisa errada. O que eu posso fazer para melhorar?" (E 2) 
"Você quer o feedback, você pede desculpas porque, às vezes, a tua abordagem não foi a melhor e você só percebe depois que passou, então as relações ficam muito mais fortes, mais consistentes, você tem as pessoas mais juntas. Isso é magnífico, isso é maravilhoso!" (E 3)

"Eu acho que é um processo e ele não é rápido, é um processo gradativo, de muito exercício de tolerância, porque é difícil ouvir o que as pessoas estão colocando e, principalmente, depende de quem está falando. É cultural. Se você tem uma imagem negativa de fulano vai ser muito difícil, você ouvir aquela pessoa. Mas a competência e o amadurecimento permitem a você trabalhar estas questões, principalmente, com os alunos." (E 8)

"O exercício da comunicação tem me conduzido ao autoconhecimento e à tentativa de conhecer o outro, à capacidade de perceber a diversidade de cada ser humano e sua expressão nas situações vivenciadas. Creio que aprendi a respeitar a mim mesma e ao outro." (E 10)

Por meio destes resultados, reafirmamos o referencial de Rogers ${ }^{(17)}$, quando assume que o professor é um ser humano como outro qualquer, tem empatia, emoções e relaciona-se com o ambiente, de acordo com suas vivências anteriores. O autor ressalta que a autenticidade do professor facilita a aprendizagem, ele se torna, então, uma pessoa real; aceita seus sentimentos, não tem necessidade de impô-los aos alunos nem insiste para que reajam da mesma forma.

O estudo de Pereira ${ }^{(18)}$ mostra a pessoa com dificuldade em se perceber e dar sentido à sua comunicação não-verbal, até a descoberta de um estilo próprio, vendo-se positiva ou negativamente nas interações.

Os aprendizes que se auto-avaliam, estão constantemente, concentrando seu aprendizado em objetivos associados ao aprendizado profundo. Em razão de seu envolvimento com os objetivos, apresentam uma apreciação mais perspicaz daquilo que estão tentando fazer, de quão bem o fazem e do que poderiam fazer a seguir para melhorar seu desempenho ${ }^{(105)}$. 
A capacidade de refletir sobre si mesmo, de se reconhecer, é de suma importância para o ensino de Enfermagem, pois partimos desta auto-avaliação para avaliarmos o aluno e conduzi-lo, também, à prática construtiva da autoavaliação.

O processo de relação permite-nos a percepção do outro e este processo caracteriza a profissão do enfermeiro, portanto, precisa ser valorizado na formação.

Em uma análise da teoria humanística, as autoras afirmam que a "Enfermagem é um diálogo vivo". São a enfermeira e o paciente relacionando-se de modo criativo e, envolvidos neste, estão o encontrar-se, o relacionar-se e o estar-presente. O diálogo tem, assim, um sentido existencial, uma forma de relação intersubjetiva, na qual um indivíduo distinto e único relaciona-se com outro $^{(106)}$.

3aㅡ categoria: Ampliação dos caminhos do ensino e da pesquisa

Outro ganho alcançado pela competência em comunicação é a condição de ampliar os caminhos do ensino e da pesquisa, pois para o ensino precisamos das habilidades comunicativas em sala de aula e para a pesquisa, escrever e expressar melhor nossas idéias. Os docentes citam que a possibilidade de aprender, ensinar, pesquisar e divulgar sobre o tema da comunicação é gratificante e proporciona oportunidades de reconhecimento de seu investimento, ressaltando que competência em comunicação permite mais clareza de pensamentos no ensino, na pesquisa, na escrita de artigos científicos, nas orientações e análise de trabalhos científicos. 
"A competência de comunicação tem um outro lado para quem está na academia como eu, porque eu trabalho com comunicação, tenho projetos de comunicação, eu faço ensino, eu tenho pessoas do grupo fazendo pesquisas nessa linha. Eu ganho oportunidade de estudar, pesquisar, ensinar e divulgar este conhecimento." (E 5)

"Mais clareza de pensamentos na trajetória de desenvolvimento pessoal e profissional na pesquisa, na escrita de artigos e reflexão, nos trabalhos. Isso contribui no desenvolvimento desses aspectos também, e até, para ensinar outras pessoas." (E 6)

"É o quanto eu tenho podido expandir isso em nível nacional e internacional. Isso também é gratificante. Todo o ser humano precisa de gratificação e um pouco de reconhecimento pelo que fez." (E 2)

"Recebo convites para eventos e os aceito sempre que posso. As pessoas expressam que gostam muito da abordagem do tema, aceito pelo prazer de compartilhar com colegas e pelo compromisso com a profissão. É este o ganho que me seduz."

(E 12)

As pessoas apresentam-se, vivem, convivem, agem, interagem, avaliam ou são avaliadas em função de competências, portanto, devem ser capazes de se expressar, argumentar e mobilizar saberes. O ensino é responsável por fornecer meios e instrumentos para o desenvolvimento destas capacidades, sobretudo, quando entendemos que a mobilização de saberes supõe recorrer ao que se sabe para realizar o que se deseja e o que se projeta ${ }^{(107)}$.

$\operatorname{Demo}^{(100)}$ localiza a pesquisa como uma forma de saber pensar, argumentar, fundamentar e intervir de modo alternativo, mas adverte que esta habilidade não pode ser vista apenas no plano individual e sim, que seja viabilizada como um processo coletivo de produção de conhecimento. 
A interação profissional e pessoal pode ser um fator de facilidade, bem como de dificuldade nas atividades grupais $^{(94)}$, mas acreditamos que uma das formas de ampliação do ensino de comunicação em Enfermagem é investir nessa interação para a produção do conhecimento de modo coletivo.

\section{4aㅡ categoria: A conquista do bem-estar}

A conquista do bem-estar aparece como um ganho final, expressado como tranqüilidade e conscientização de estar tentando fazer melhor todas as coisas e, assim, a vida ficando mais prazerosa.

Os entrevistados ressaltam aspectos de crescimento pessoal e profissional, resultando em melhores relacionamentos. Afirmam que sabem cuidar e se deixar cuidar, que aprenderam a lidar com as próprias limitações e com as dos outros. Sentem-se preparados para aceitar e compreender a si e aos outros.

Finalmente, expressam que sentem um bem-estar, um estado de perfeita satisfação, reafirmando que a competência em comunicação é um mundo que se abre para quem quer estar próximo das pessoas.

"Cada vez que eu me comunico e me preocupo que tenha eficiência, qualidade, isso me ajuda a me conhecer melhor e, por conseqüência, ajuda na vida pessoal e em todas as esferas da minha vida, diminuindo um pouco a carga, e a vida vai ficando mais prazerosa." (E 1)

"Bem-estar, qualidade de vida. Por quê eu falo isso? Porque eu me sinto muito bem, realizada. Quando eu paro para pensar como eu era e como eu sou hoje, para mim é uma maravilha. Não que eu me ache perfeita. Não sou mesmo! Tenho as minhas irritações, minhas coisas... Eu não deixo de ser, ser humano. Sou uma pessoa e tenho qualidades e defeitos, mas 
quando eu comparo o que eu era e o que eu sou hoje e o que de comunicação interferiu nisso, nossa! Eu fico na maior felicidade do mundo." (E 2)

"É um mundo que se abre, é um fator de embelezamento da vida para a gente que quer ficar com as pessoas, quer lidar com as pessoas, seja onde for, na educação, na saúde ou no comércio." (E 3)

"Sou uma pessoa extremamente rica com o que ganho trabalhando essas questões com as pessoas: a certeza de que é possível, através da comunicação, possibilitar momentos de bem-estar." (E 7)

"Posso crescer, amadurecer e ajudar outros a crescerem; ajudar e receber ajuda; relacionar-me melhor com os outros e comigo mesmo; trilhar o processo de tornar-me pessoa; amar e ser amada; cuidar e ser cuidada; aumentar minha congruência e ajudar outros a aumentarem a deles; ser mais feliz e fazer os outros mais felizes; conhecer a mim e aos outros melhor e ajudar a outrem nesse processo; ser mais assertiva e ajudar outrem a desenvolver a sua assertividade; aprender a lidar com minhas limitações e aceitar as limitações dos outros; compreender e ser compreendida, aceitar e ser aceita."(E 13)

Satir ${ }^{(42)}$ denomina de comunicação congruente aquela que constrói a autoestima e a do outro, afirma que a congruência vem da correspondência entre as palavras e os sentimentos, entre as expressões corporais, faciais e as palavras verbalizadas. É um estado de força, no que todas as facetas estão fluindo e interagindo, existindo clareza de expressão, de confiabilidade e possibilidade da escolha. A congruência, também citada por autores como Rogers ${ }^{(53)}$, Silva ${ }^{(11)}$, Rocha(1), é uma semente de possibilidades, de criar idéias e fazer as coisas funcionarem melhor, unir-se aos outros e fazer julgamentos válidos. A congruência e ou coerência permite ser saudável, ter relacionamentos positivos e a alegria de uma vida plena. 
"Todas as vezes em que tive algo a dizer,

eu disse da maneira que senti ser boa.

Motivos diferentes exigem

métodos diferentes.

Isso não implica nem em evolução,

nem em progresso,

mas num consenso

entre a idéia que se deseja expressar

e os meios de expressá-la."

Pablo Picasso

\section{CONCLUSÕES E CONSIDERAÇÕES FINAIS}


Partindo do pressuposto que as pessoas são ou não são competentes e que a personalidade é característica fundamental da idéia de competência ${ }^{(107)}$, apresentamos as conclusões deste estudo, nas quais os participantes caracterizam os referenciais de competências comunicativas interpessoais, apresentando significados para a comunicação competente, relatando como a expressam, como a desenvolvem, e o que ganham investindo nessa busca.

Uma configuração de bases teórico-metodológicas para o aprendizado da comunicação interpessoal em Enfermagem, também, é contemplada neste estudo.

\subsection{Os referenciais de competências comunicativas interpessoais para 0 ensino da Enfermagem}

Os significados atribuídos a uma comunicação competente representam que a competência nessa área reconhece a comunicação como um processo interpessoal, que deve atingir o objetivo dos comunicadores, pressupor conhecimentos básicos de comunicação, ter consciência do verbal e do nãoverbal nas interações, atuar com clareza e objetividade e promover o autoconhecimento, e por conseqüência, uma comunicação competente possibilita uma vida mais autêntica.

A expressão da competência comunicativa interpessoal está, necessariamente, no vivenciar o cotidiano profissional e pessoal, ouvindo o outro, prestando atenção na comunicação não-verbal, validando a compreensão das mensagens, sendo capaz de eliminar as barreiras impostas à comunicação, demonstrando afetividade e investindo no autoconhecimento. 
O desenvolvimento da competência comunicativa verifica-se no estímulo recebido desde a graduação, pelas leituras de aprofundamento do tema, pela prática profissional e realização de pesquisas e publicações na área.

O ganho alcançado com a competência em comunicação interpessoal resulta em relações profissionais e pessoais mais significativas, maior autoconsciência e aceitação das diferenças do outro, ampliação dos caminhos do ensino e da pesquisa e, conseqüentemente, a conquista de um bem-estar.

\subsection{As bases teórico-metodológicas para o aprendizado da comunicação interpessoal em Enfermagem}

Os referenciais teóricos que instrumentalizam a competência em comunicação na Enfermagem, estão situados, basicamente, como referenciais de competência interpessoal.

Foram citados quarenta teóricos de comunicação, e 11 deles, por mais de dois participantes do estudo, o que parece caracterizá-los como os mais aceitos para referenciais comunicativos na Enfermagem, são eles:

- STEFANELLI, Maguida Costa;

- SILVA, Maria Júlia Paes;

- TRAVELBEE, Joyce;

- LITTLEJOHN, Stephen W.;

- DAVIS, Flora;

- ROGERS, Carl R.;

- SULLIVAN, Harry Stack; 
- RUESCH, Jurgen;

- PEPLAU, Hildegard E.;

- BALES, Robert F.;

- MOSCOVICI, Fela.

Dos teóricos representados pelos sujeitos do estudo, destacamos proposições que podem se configurar como referenciais para o aprendizado da comunicação interpessoal em Enfermagem:

- a comunicação é um processo interpessoal que permeia toda a ação do enfermeiro como fator significativo para o bem-estar do paciente. É uma capacidade que pode ser adquirida ${ }^{(41)}$;

- a comunicação interpessoal ocorre no contexto da interação face a face e, entre os aspectos envolvidos nesse processo estão as tentativas de compreender e de se fazer compreendido, além da percepção, da possibilidade de conflitos e de persuasão ${ }^{(11)}$;

- ao interagirmos verbalmente com alguém, por meio da escrita ou da fala, estamos tentando nos expressar, clarificar um fato ou validar a compreensão de $\operatorname{algo}^{(11,41)}$;

- a comunicação não-verbal é toda informação transmitida por gestos, posturas, expressões faciais, orientações do corpo, singularidades somáticas, organização dos objetos no espaço e relação de distância mantida entre os indivíduos ${ }^{(11)}$;

- a premissa básica da comunicação não-verbal é que o indivíduo participa, simultaneamente, de duas dimensões existenciais 
decorrentes de dois modos de se relacionar com o mundo: uma verbal, que lhe confere um estatuto psicolingüístico e outra nãoverbal, que lhe confere um estatuto psicobiológico ${ }^{(11)}$;

- o enfermeiro deve mostrar-se interessado em ajudar os outros a se ajudarem e, nessa relação de ajuda, é imprescindível infundir no outro o sentimento de confiança para que ele consiga se expor e ter esperanças de beneficiar-se ${ }^{(51,52)}$;

- a comunicação é um processo de interação simbólica, pois é constituída pela emissão e recepção de mensagens codificadas ${ }^{(2,3)}$;

- as pessoas têm necessidades interpessoais de inclusão, controle e afeição e sua satisfação ou não, define o comportamento dos indivíduos ${ }^{(2)}$;

- o relacionamento interpessoal é facilitador da aprendizagem e quando autêntico é profundamente capaz de suscitar crescimento $^{(17,53)}$;

- o autoconhecimento só pode ser obtido com a ajuda dos outros, por meio de feeback ${ }^{(4)}$;

- é impossível eliminar totalmente os obstáculos da comunicação, mas devemos saber onde os estamos criando e reduzi-los ao máximo possível ${ }^{(55)}$;

- é importante termos um objetivo na comunicação e defini-lo, além disso, as pessoas devem analisar seus objetivos e especificá-los em termos das reações que pretendem obter ${ }^{(56)}$; 
- as emoções podem produzir comprometimento e dedicação, mas também desinteresse e indiferença ${ }^{(57)}$;

- a clarificação das mensagens, o feedback e a comunicação terapêutica são fundamentais nas relações interpessoais que envolvem o cuidar ${ }^{(46)}$;

- a comunicação implica reciprocidade, desta forma, não existem sujeitos passivos, pois a comunicação é diálogo ${ }^{(59,60)}$;

- todo comportamento tem valor de mensagem, portanto, é impossível não comunicar ${ }^{(21)}$.

A partir do exposto, as bases metodológicas emergentes para o aprendizado e ensino da comunicação interpessoal em Enfermagem são:

- assumir a comunicação como base para o cuidar em Enfermagem;

- ensinar os fundamentos teóricos da comunicação no início da graduação;

- desenvolver a competência de todos os professores em comunicação;

- vincular a prática assistencial com o ensino da comunicação;

- acompanhar a progressão da competência comunicativa no aluno:

> observando a evolução das habilidades comunicativas, viabilizando momentos para expressão de pensamentos, sentimentos e percepções, fornecendo feedback e estimulando-os, realizando avaliação formativa e tutorando o aluno;

- vivenciar a comunicação efetiva com as pessoas na escola. 


\subsection{Considerações Finais}

A aquisição da habilidade em comunicação interpessoal deve basear-se em uma abertura na relação professor-aluno, aquela que permite troca, reciprocidade e aponta um caminho de formação com benefícios profissionais e pessoais.

Sabemos que as relações interpessoais autênticas promovem a capacidade de compreensão dos sentimentos e pensamentos próprios e do outro. $\mathrm{Na}$ formação, estas interações não podem ser casuais, devem ter objetivos educacionais a serem atingidos, pois as competências não estão estabelecidas, mas são construídas no cotidiano das relações.

É tarefa fundamental do professor semear desejos, estimular projetos, consolidar valores que os sustentem e, sobretudo, fazer com que os alunos saibam articular seus projetos pessoais com os da coletividade, na qual se inserem, tornando-se, portanto, competentes ${ }^{(107)}$.

Na construção das competências comunicativas, a motivação é necessária e o professor deve criar estas condições na formação do enfermeiro, pois este terá o compromisso de interpretar os sinais de seu meio e as influências culturais envolvidas no cuidar.

Morin ${ }^{(101)}$ chama de "unidualidade" a condição do ser humano ser totalmente biológico e cultural a um só tempo, reafirmando que o homem só se realiza como ser humano pela cultura e na cultura.

No aspecto da "unidualidade", estão as reflexões de Perrenoud ${ }^{(86)}$ ao considerar a pessoa do professor, sua cultura e a relação que instaura com os alunos, individual ou coletivamente, como sua principal ferramenta de trabalho, 
pois mesmo que a formação esteja centrada nos saberes, na didática, na avaliação, na gestão de classe e nas tecnologias, a pessoa do professor intervém na relação:

- com o saber, com o erro, com a ignorância;

- com o risco, com a incerteza;

- com a ordem (e a desordem), com o imprevisto, com a regra (e o desvio dela);

- com o tempo, com o planejamento, com a obediência a ele, com a improvisação;

- com a ausência ou com o atraso dos outros, com suas emoções e expectativas;

- com as diferenças entre as pessoas, com a distância interpessoal ou intercultural;

- com a escrita, com a palavra, com o silêncio;

- com o poder, com a autoridade, com a instituição;

- com o conflito, com a negociação, com as relações de força;

- com os objetos e com os procedimentos técnicos;

- com o trabalho, com o jogo, com a atividade, com o ócio;

- com as hierarquias de excelência, com as classificações, com a avaliação;

- com as desigualdades, com as injustiças;

- com o sofrimento, com a frustração; e o prazer, entre outros. 
A conscientização da complexidade do tema da comunicação humana, especificamente, das relações interpessoais não nos permite afirmações estanques, mas, a possibilidade de mostrar que existem pessoas atentas para o significado de uma comunicação interpessoal competente na Enfermagem.

Os referenciais teóricos utilizados pelos estudiosos da área de comunicação em Enfermagem fornecem um embasamento para a comunicação verbal e não-verbal, incluindo situações interpessoais de grupo e organizacionais.

Os estudiosos afirmam que a Enfermagem é um processo interpessoal, simbólico e complexo e que o enfermeiro precisa ter consciência da relação dos comportamentos verbais e não-verbais nas interações e reconhecem que as emoções, expectativas e os estereótipos interferem na comunicação, bem como o conhecimento prévio dos emissores. Acreditam na motivação como fundamental para a aquisição da habilidade em comunicação, especialmente, quando este estímulo acontece no início da graduação.

Nas palavras de Chalita(108):

"Não há sensação de pertencimento se não compartilharmos nossa vida, nossas experiências e nossos aprendizados com os que nos são ou não semelhantes."

Os resultados que emergiram deste estudo, permitem que consideremos a competência em comunicação interpessoal como uma habilidade fundamental a ser adquirida pelo enfermeiro, sabendo que esta lhe possibilitará um cuidar consciente, verdadeiro e transformador. 
Acreditamos que cuidar de modo transformador é um cuidar que, na interação e nas trocas de experiências, vê o outro, aluno, paciente, colega, de maneira inteira e, assim, o comunicar será um conviver que humaniza. 
REFERÊNCIAS 
1. Rocha EM. Comportamento comunicativo do docente de enfermagem e sua influência na aprendizagem do educando. [dissertação]. São Paulo (SP): Escola de Enfermagem da USP; 1999.

2. Littlejohn SW. Fundamentos teóricos da comunicação humana. Rio de Janeiro: Guanabara; 1988.

3. Bordenave JED. O que é comunicação. São Paulo: Brasiliense; 2004 (Coleção Primeiros Passos).

4. Moscovici F. Desenvolvimento interpessoal. $7^{\text {a }}$ ed. Rio de Janeiro: José Olympio; 1997.

5. Gaiarsa JA. O espelho mágico: um fenômeno social chamado corpo e alma. São Paulo: Summus; 1984.

6. Bezerra DB. Implicações pedagógicas da comunicação interativa. [dissertação]. São Paulo (SP): Faculdade de Educação da Universidade Mackenzie; 1996.

7. Gagné RM. Como se realiza a aprendizagem. Rio de Janeiro: Livros Técnicos e Científicos; 1974.

8. Ausubel DP, Novak JD, Hanesian H. Psicologia educacional. $2^{\text {a }}$ ed. Rio de Janeiro: Interamericana; 1980.

9. Bordenave JD, Pereira AM. Estratégias de ensino-aprendizagem. $15^{\mathrm{a}}$ ed. Petrópolis: Vozes; 1995.

10. Masetto MT, Abreu MC. O professor universitário em aula. $8^{a}$ ed. São Paulo: MG Editores Associados; 1990. 
11. Silva MJP. Comunicação tem remédio: a comunicação nas relações

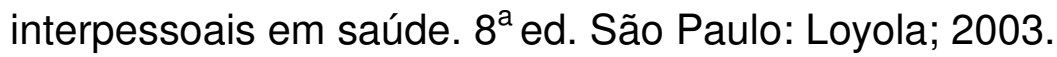

12. Masetto MT. Aulas vivas. São Paulo: MG Editores Associados; 1992.

13. Poplin M, Weeres J. Listening at the learner"s level. Exec Educ 1993; 15(4):14-9.

14. Rocha EM, Silva MJP. Comportamento comunicativo do docente de enfermagem e sua influência na aprendizagem do educando. Nursing 2001; 4(32):30-4. (edição brasileira).

15. Gadotti M. Comunicação docente. $3^{\mathrm{a}}$ ed. São Paulo: Loyola; 1985.

16. Perrenoud P. 10 novas competências para ensinar. Porto Alegre: Artmed; 2000.

17. Rogers CR. Tornar-se pessoa. $4^{\mathrm{a}}$ ed. São Paulo: Martins Fontes; 1991.

18. Pereira LL. Vivenciando a comunicação como descoberta. [tese]. São Paulo (SP): Escola de Enfermagem da USP; 1999.

19. Gaiarsa JA. O que é corpo. 7ํㅡ ed. São Paulo: Brasiliense; 2002. (Coleção Primeiros Passos).

20. Alves R. Conversas com quem gosta de ensinar. São Paulo: Ars Poética; 1995.

21. Watzlawick $P$, Beavin $\mathrm{JH}$, Jackson DD. Pragmática da comunicação

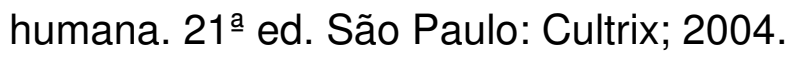


22. Silva AF. Refletindo o ensinar em enfermagem. Cad UniABC Enferm $2000 ;(8): 47-51$.

23. Peres HHC, Leite MMJ, Kurcgant P. A percepção dos docentes universitários à respeito de sua capacitação para o ensino em enfermagem. Rev Esc Enferm USP 1988; 32(1):52-8.

24. Demo P. Educar pela pesquisa. 4ํㅗㄹ ed. Campinas: Autores Associados; 2000. (Coleção Educação Contemporânea).

25. Perrenoud P. Construir as competências desde a escola. Porto Alegre: Artes Médicas; 1999.

26. Demo P. Educação e qualidade. $3^{a}$ ed. São Paulo: Papirus; 1997.

27. Pinheiro VE, Rodrigues ARF. O processo ensino/aprendizagem na enfermagem. Enferm Rev Belo Horizonte 1999; 5(9/10):62-79.

28. Belloni ML. Tecnologia e formação de professores: rumo a uma pedagogia pós-moderna. Educ Soc 1998; 19(65):81-3.

29. De Domenico EBL. Referenciais de competências segundo níveis de formação superior em Enfermagem: a expressão do conjunto. [tese]. São Paulo (SP): Escola de Enfermagem da USP; 2003.

30. Magalhães LMT. O ensino superior em enfermagem e o desafio da mudança: os referenciais de um novo processo de formação. [tese]. São Paulo (SP): Escola de Enfermagem da USP; 2000.

31. Conselho Nacional de Educação. Diretrizes curriculares nacionais da saúde. [on line] Brasília (DF); 2001. Disponível em: http://www.mec.gov.br (20 nov 2001). 
32. Ide CAC, Chaves EC. Educação em enfermagem: o movimento constituinte da sua identidade. Rev Esc Enferm USP 1996; 30(3):371-9.

33. Angelo M. Educação em enfermagem. Rev Esc Enferm USP 1994; 28(1):11-4.

34. Bagnato MHS. Formação crítica dos profissionais da área de enfermagem. Texto Contexto Enferm 1999; 8(1):31-42.

35. Enr E, Backes VMS. Currículo: aspectos que educadores e educandos da enfermagem devem conhecer. Texto Contexto Enferm 1999; 8(1):4352.

36. Sandoval JMH. O discurso teórico-metodológico em pesquisas de comunicação em enfermagem. [tese]. São Paulo (SP): Escola de Comunicações e Artes da USP; 1994.

37. Silva MJP. Construção e validação de um programa sobre comunicação não-verbal para enfermeiros. [tese]. São Paulo (SP): Escola de Enfermagem da USP; 1993.

38. Silva MJP. Análise comparativa da aplicação de um programa sobre comunicação não-verbal para enfermeiros hospitalares. [tese livre docência]. São Paulo (SP): Escola de Enfermagem da USP; 1998.

39. Minayo MCS. Pesquisa social: teoria, método e criatividade. Rio de Janeiro: Vozes; 1994.

40. Bardin L. Análise de conteúdo. São Paulo: Edições 70; 1977. 
41. Stefanelli MC. Comunicação com paciente: teoria e ensino. $2^{a}$ ed. São Paulo: Robe; 1993.

42. Satir V. Contatos com tato. São Paulo: Editora Gente; 2000.

43. Bachion MM. Comunicação interpessoal: ensino de algumas habilidades desejadas. [tese]. Ribeirão Preto (SP): Escola de Enfermagem de Ribeirão Preto/USP; 1994.

44. Carvalho EC. Enfermagem e comunicação: a interface. [tese livre docência]. Ribeirão Preto (SP): Escola de Enfermagem de Ribeirão Preto/USP; 1989.

45. Rios TA. Ética e competência. 10ª ed. São Paulo: Cortez; 2001.

46. Blondis MN, Jackson BE. Nonverbal communication with patients. $2^{\text {nd }}$ ed. New York: A Wiley Medical Publication; 1982.

47. Birdwhistell RL. Kinesis and context. Philadelphia: Pennsylvania Press; 1970.

48. Davis F. A comunicação não-verbal. 5ª ed. São Paulo: Summus; 1979.

49. Luft J, Ingham H. The Johari Window: a graphic model for interpersonal relations. Washisgton: Human Relations Training News; 1961.

50. Rios TA. Compreender e ensinar: por uma docência da melhor qualidade. São Paulo: Cortez; 2001.

51. Ivo ML, Furegato AR. Relacionamento interpessoal analisado à luz do referencial de Travelbee. Nursing 1999; 2(10):18-24. (edição brasileira). 
52. Travelbee J. Intervención em enfermeria psiquiátrica: el processo de la relacion de persona a persona. Washington: Organización Panamericana de Salud; 1979.

53. Rogers CR. Liberdade para aprender. $2^{\mathrm{a}}$ ed. Belo Horizonte: Interlivros; 1973.

54. Fritzen SJ. Janela de johari: exercícios vivenciais de dinâmica de grupo, relações humanas e de sensibilidade. Petrópolis: Vozes; 1986.

55. Benjamin A. A entrevista de ajuda. 9aㅡ ed. São Paulo: Martins Fontes; 1998.

56. Berlo DK. O processo da comunicação. São Paulo: Martins Fontes; 1979.

57. Blake RR, Mouton JHS. Estruturação de uma empresa dinâmica através do desenvolvimento organizacional do tipo grid. São Paulo: Edgard Blucher; 1972.

58. Chanlat JF. O indivíduo na organização: dimensões esquecidas. São Paulo: Atlas; 1993.

59. Freire P. Extensão ou comunicação? 9a ed. Rio de Janeiro: Paz e Terra; 1977.

60. Freire P. Pedagogia da Autonomia: saberes necessários à prática educativa. 6를 ed. Rio de Janeiro: Paz e Terra; 1997. (Coleção Leitura).

61. Furnham A. linguagem corporal no trabalho. São Paulo: Nobel; 2001. 
62. Geuss R. Teoria crítica: Habermas e a Escola de Frankfurt. Campinas: Papirus; 1988.

63. Demo P. Pesquisa e construção de conhecimento: metodologia científica no caminho de Habermas. Rio de Janeiro: Tempo Brasileiro; 1994.

64. Hall ET. A dimensão oculta. Lisboa: Relógio d’Água; 1986.

65. Galvão CM, Sawada NO, Castro AP, Carniani F. Liderança e comunicação: estratégias essenciais para o gerenciamento da assistência de enfermagem no contexto hospitalar. Rev Lat Am Enferm 2000; 8(5):34-43.

66. Hersey $\mathrm{P}$, Blanchard $\mathrm{KH}$. Psicologia para administradores: teoria e as técnicas da liderança situacional. São Paulo: EPU; 1986.

67. George JB. Teorias de enfermagem: os fundamentos para a prática profissional. Trad. de Ana Maria Vasconcellos Thorell. 4aㅗ ed. Porto Alegre: Artes Médicas; 1993.

68. Knapp ML. Essentials of nonverbal communication. New York: Holt Rinehart and Winston; 1980.

69. Kessler II, Levin ML. The community as an epidemiologic laboratory: a casebook of community studies. Baltimore: Johns Hopkins Press; 1970.

70. Machado MH. Assistência de enfermagem centrada na pessoa: uma aplicação em ambulatório de hospital geral. [tese livre docência]. Ribeirão Preto (SP): Escola de Enfermagem de Ribeirão Preto/USP; 1980. 
71. Manzolli MC. Formação do enfermeiro. São Paulo: Sarvier; 1985.

72. Manzolli MC. Relacionamento em enfermagem. São Paulo: Sarvier; 1987.

73. Mendes IAC. Enfoque humanístico à comunicação em enfermagem. São Paulo: Sarvier; 1994.

74. Moreno JL. Fundamentos do psicodrama. São Paulo: Summus; 1983.

75. Parra N. Caminhos do ensino. São Paulo: Pioneira Thomson Learning; 2002.

76. Skinner BF. Tecnologia do ensino. São Paulo: EPU/EDUSP; 1972.

77. Sommer R. Espaço pessoal: as bases comportamentais de projetos e planejamentos. São Paulo: EPU; 1973.

78. Sundeen SJ, Stuart GW, Rankin EAD, Cohen SA. Nurse-client interaction: implementing the nursing process. $6^{\text {th }}$ ed. Saint Louis: Mosby; 1998.

79. Watson J. Nursing: human science and human care. Norwalk: Appleton Century Crofts; 1985.

80. Silva RM, Gurgel AH, Moura ERF. Ética no processo ensinoaprendizagem em enfermagem obstétrica. Rev Esc Enferm USP 2004; $38(1): 28-36$.

81. Gabrielli JMW, Pelá NTR. O professor real e o ideal na visão de um grupo de graduandos de enfermagem. Rev Esc Enferm USP 2004; 38(2):168-74. 
82. Bicudo MAV. Fundamentos éticos da educação. São Paulo: Cortez; 1982.

83. Sadala MLA. O cuidar que é educar: o olhar fenomenológico. In: Capelletti IF, Lima LAN, organisadores. Formação de educadores: pesquisas e estudos qualitativos. São Paulo: Olho d'Água; 1999. p. 3764.

84. Pinheiro EM. Sendo mediada pela força da motivação: o significado da comunicação para as profissionais de enfermagem na interação com o recém-nascido e a família. [tese]. São Paulo (SP): Escola de Enfermagem da USP; 2003.

85. Assad LG, Viana LO. Saberes práticos na formação do enfermeiro. Rev Bras.Enferm 2003; 56(1):44-7.

86. Perrenoud P. A prática reflexiva no ofício de professor: profissionalização e razão pedagógica. Porto Alegre: Artmed; 2002.

87. Ramos FRS, Paião MRRS, Stefan A, Pereira EP. A pesquisa como experiência educativa: produções e percepções no ensino de graduação. Texto Contexto Enferm 1999; 8(1):222-42.

88. Dell'Acqua MCQ. A construção da competência clínica: da concepção dos planejamentos de ensino às representações da aprendizagem entre graduandos de enfermagem. [tese]. São Paulo (SP): Escola de Enfermagem da USP; 2004.

89. Waldow VR. Examinando o conhecimento na enfermagem. In: Meyer DE, Waldow VR, Lopes MJM. Marcas da diversidade: saberes e fazeres 
da enfermagem contemporânea. Porto Alegre: Artes Médicas; 1998. p. 53-85.

90. Waldow VR, Lopes MJM, Meyer DE. Maneiras de cuidar, maneiras de ensinar: a enfermagem entre a escola e a prática profissional. Porto Alegre: Artes Médicas; 1995.

91. Ide CAC, De Domenico EBL. A proposta construtivista no ensino da enfermagem. In: Ide CAC, De Domenico EBL. Ensinando e aprendendo um novo estilo de cuidar. São Paulo: Atheneu; 2001. p.109-18.

92. Nimtz MA. O significado de competência para 0 docente de administração em enfermagem. [tese]. São Paulo (SP): Escola de Enfermagem da USP; 2003.

93. Gadotti M. Educação e poder: introdução à pedagogia do conflito. $12^{\underline{a}}$ ed. São Paulo: Cortez; 2001.

94. Braga EM, Sangiuliano LA, Silva MVG, Silva MJP. A comunicação em grupo entre profissionais de saúde. Nursing 2004; 7(73):36-41. (edição brasileira).

95. Perrenoud P. Pedagogia diferenciada: das intenções à ação. Porto Alegre: Artes Médicas; 2000.

96. Gaiarsa JA. O olhar. São Paulo: Gente; 2000.

97. Lourenço MR, Zborowski IP, Trevisan MA. Comunicação: análise de obstáculos entre os enfermeiros. In: Mendes IAC, Carvalho EC. Comunicação como meio de promover saúde. Ribeirão Preto: Scala; 2000. p. 43-7. 
98. Antunes C. Como transformar informações em conhecimento. $3^{\text {a }}$ ed. Petrópolis: Vozes; 2001.

99. Zabala A. Aprática educativa. Porto Alegre: Artes Médicas; 1998.

100. Demo P. Complexidade e aprendizagem: a dinâmica não linear do conhecimento. São Paulo: Atlas; 2002.

101. Morin E. Os sete saberes necessários à educação do futuro. $8^{\underline{a}}$ ed. São Paulo: Cortez; 2003.

102. Valsecchi EASS, Nogueira MS. Comunicação professor aluno: aspectos relacionados ao estágio supervisionado. In: Mendes IAC, Carvalho EC. Comunicação como meio de promover saúde. Ribeirão Preto: Scala; 2000. p. 99-103.

103. Melo MLA. A sala de aula na universidade: da etologia à fenomenologia. In: Capelletti IF, Lima LAN, organizadores. Formação de educadores: pesquisas e estudos qualitativos. São Paulo: Olho'Água; 1999. p. 19-35.

104. Castro RCBR. Programa sobre a comunicação não-verbal para a equipe de enfermagem baseado nos preceitos da reforma psiquiátrica. [tese]. São Paulo (SP): Escola de Enfermagem da USP; 2003.

105. Cowan J. Como ser um professor universitário inovador. Porto Alegre: Artmed; 2002.

106. Pagliuca LMF, Campos ACSC. Teoria humanística: análise semântica do conceito de community. Rev Bras Enferm 2003; 56(6):655-60.

107. Machado NJ. Sobre a idéia de competência. In: Perrenoud P, Thurler MG, Macedo L, Machado NJ, Allessandrini CD. As competências para 
ensinar no século XXI: a formação dos professores e o desafio da avaliação. Porto Alegre: Artmed; 2002. p. 137-55.

108. Chalita G. Pedagogia do amor: a contribuição das histórias universais para a formação de valores das novas gerações. São Paulo: Gente; 2003. 
ANEXOS 


\section{ANEXO I}

\section{PARECER DO COMITÊ DE ÉTICA EM PESQUISA}

\section{unesp

Prezada Senhora

Profa. Eliana Mara Rocha

Departamento de Enfermagem

da Faculdade de Medicina de Botucatu

Prezada Professora,

De ordem da Senhora Presidente deste CEP, informo que o Projeto de Pesquisa intitulado "Comportamentos comunicativos adotados pelos professores de enfermagem que facilitam a aprendizagem", de sua autoria com a orientação da Profa $\mathrm{Dr}^{\mathrm{a}}$ Marli Alves Rolim, recebeu do relator parecer Favorável, aprovado em reunião de 04/02/2002

Sendo só para o momento, aproveito o ensejo para renovar os protestos de elevada estima e distinta consideração.

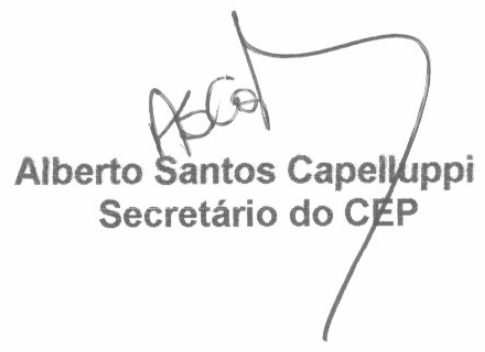




\section{ANEXO II \\ TERMO DE CONSENTIMENTO LIVRE E ESCLARECIDO}

Eu, Eliana Mara Braga autora do projeto de pesquisa intitulado "Comportamentos comunicativos dos docentes de Enfermagem que facilitam a aprendizagem", venho solicitar seu consentimento para sua realização, que tem como objetivos caracterizar referenciais de competências comunicativas para o ensino da Enfermagem e propor bases teórico-metodológicas ao aprendizado da comunicação em Enfermagem. Pretendo realizar a coleta de dados por meio de uma entrevista gravada, composta por questões norteadoras, para que você discorra sobre elas. As fitas gravadas serão utilizadas apenas para transcrição dos dados e, a seguir, serão destruídas.

Você terá, a qualquer momento, direito a esclarecimentos sobre quaisquer dúvidas que venham ocorrer a respeito dos assuntos abordados pela pesquisa.

Você tem a garantia do sigilo e do caráter confidencial das informações que estará prestando à pesquisadora, sabendo de antemão que elas serão usadas com a finalidade única de divulgação e publicação científica, sempre garantindo sua privacidade.

Caso sinta-se satisfatoriamente informado sobre esta pesquisa e concorde em participar dela, solicitamos seu consentimento, ressaltando que estamos à sua disposição para quaisquer dúvidas e que este consentimento pode ser retirado a qualquer tempo.

Data

Assinatura do participante

Responsável pelo projeto:

Eliana Mara Braga

Prof ${ }^{\mathrm{a}}$ Assistente do Departamento de Enfermagem da FMB-UNESP

Doutoranda da Escola de Enfermagem da USP-SP

Rua: Carlos Guadagnini, 1214

CEP: 18610-120- Botucatu-SP

Telefone/fax: (14) 38135264 
$V_{m}$ jovem passou a vida estudando o que era a iluminação. $V_{m}$ dia, ao ver um ancião que descia uma trilha com um pesado fardo às costas, sentiu que finalmente encontrara um sábio capaz de responder às suas mais intimas perguntas. Desculpando-se, aproximou-se do vetho e pediu que ele the explicasse o significado da iluminação.

O velhinho sorriu e parou. Tirou o alforje das costas, depositou-o no chão, endireitou o corpo e olhou para o jovem com um othar cheio de amor.

Os olhos do jovem se encheram de lágrimas de alegria: "Compreendo! ele disse. "Mas por favor, preciso saber o que vem depois da iluminação."

$O$ ancião respirou fundo, repôs o alforje nas costas $e$ continuou caminhando.

(História Zen)

Extraído do livro:

"Amor é o caminho" Autor: Maria Júlia Paes da Silva 


\section{Autorização para reprodução}

Autorizo a reprodução deste trabalho.

São Paulo, 01 de outubro de 2004.

ELIANA MARA BRAGA 